\title{
Class A Orphans in GtoPdb v.2021.3
}

Stephen P.H. Alexander ${ }^{1}$, Jim Battey ${ }^{2}$, Helen E. Benson ${ }^{3}$, Richard V. Benya ${ }^{4}$, Tom I. Bonner ${ }^{5}$, Anthony P. Davenport ${ }^{6}$, Khuraijam Dhanachandra Singh ${ }^{7}$, Satoru Eguchi ${ }^{8}$, Anthony Harmar ${ }^{3}$, Nick Holliday $^{1}$, Robert T. Jensen ${ }^{2}$, Sadashiva Karnik ${ }^{7}$, Evi Kostenis ${ }^{9}$, Wen Chiy Liew ${ }^{3}$, Amy E. Monaghan ${ }^{3}$, Chido Mpamhanga ${ }^{10}$, Richard Neubig ${ }^{11}$, Adam J Pawson ${ }^{12}$, Jean-Philippe Pin ${ }^{13}$, Joanna L. Sharman ${ }^{3}$, Michael Spedding ${ }^{14}$, Eliot Spindel ${ }^{15}$, Leigh Stoddart ${ }^{16}$, Laura Storjohann ${ }^{17}$, Walter G. Thomas ${ }^{18}$, Kalyan Tirupula ${ }^{7}$ and Patrick Vanderheyden ${ }^{19}$

1. University of Nottingham, UK

2. National Institutes of Health, USA

3. University of Edinburgh, UK

4. University of Illinois at Chicago, USA

5. National Institute of Mental Health, USA

6. University of Cambridge, UK

7. Cleveland Clinic Lerner Research Institute, USA

8. Temple University, USA

9. University of Bonn, Germany

10. LifeArc, UK

11. Michigan State University, USA

12. The University of Edinburgh, UK

13. Université de Montpellier, France

14. Spedding Research Solutions SARL, France

15. Oregon Health \& Science University, USA

16. University of Glasgow, UK

17. University of Utah, USA

18. University of Queensland, Australia

19. Vrije Universiteit Brussel, Belgium

\begin{abstract} with as-yet unidentified endogenous ligands.

Table 1: Class A orphan GPCRs with putative endogenous ligands

$\begin{array}{lllllll}\text { GPR3 } & \text { GPR4 } & \text { GPR6 } & \text { GPR12 } & \text { GPR15 } & \text { GPR17 } & \text { GPR20 } \\ \text { GPR22 } & \text { GPR26 } & \text { GPR31 } & \text { GPR34 } & \text { GPR35 } & \text { GPR37 } & \text { GPR39 } \\ \text { GPR50 GPR63 } & \text { GRP65 } & \text { GPR68 } & \text { GPR75 } & \text { GPR84 } & \text { GPR87 } \\ \text { GPR88 GPR132 } & \text { GPR149 } & \text { GPR161 } & \text { GPR183 } & \text { LGR4 } & \text { LGR5 } \\ \text { LGR6 } & \text { MAS1 } & \text { MRGPRD } & \text { MRGPRX1 } & \text { MRGPRX2 } & \text { P2RY10 } & \text { TAAR2 }\end{array}$
\end{abstract}

Table 1 lists a number of putative GPCRs identified by NC-IUPHAR [161], for which preliminary evidence for an endogenous ligand has been published, or for which there exists a potential link to a disease, or disorder. These GPCRs have recently been reviewed in detail [121]. The GPCRs in Table 1 are all Class A, rhodopsin-like GPCRs. Class A orphan GPCRs not listed in Table 1 are putative GPCRs

In addition the orphan receptors GPR18, GPR55 and GPR119 which are reported to respond to endogenous agents analogous to the endogenous cannabinoid ligands have been grouped together (GPR18, GPR55 and GPR119).

\section{Contents}

This is a citation summary for Class A Orphans in the Guide to Pharmacology database (GtoPdb). It exists purely as an adjunct to the database to facilitate the recognition of citations to and from the database by citation analyzers. Readers will almost certainly want to visit the relevant sections of the 
database which are given here under database links.

GtoPdb is an expert-driven guide to pharmacological targets and the substances that act on them. GtoPdb is a reference work which is most usefully represented as an on-line database. As in any publication this work should be appropriately cited, and the papers it cites should also be recognized. This document provides a citation for the relevant parts of the database, and also provides a reference list for the research cited by those parts. For further details see [68].

Please note that the database version for the citations given in GtoPdb are to the most recent preceding version in which the family or its subfamilies and targets were substantially changed. The links below are to the current version. If you need to consult the cited version, rather than the most recent version, please contact the GtoPdb curators.

\section{Database links}

Class A Orphans

https://www.guidetopharmacology.org/GRAC/FamilyDisplayForward?familyId=16

Introduction to Class A Orphans

https://www.guidetopharmacology.org/GRAC/FamilyIntroductionForward?familyId=16

Receptors

GPR3

https://www.guidetopharmacology.org/GRAC/ObjectDisplayForward?objectId=83

GPR4

https://www.guidetopharmacology.org/GRAC/ObjectDisplayForward?objectId=84 GPR6

https://www.guidetopharmacology.org/GRAC/ObjectDisplayForward?objectId=85 GPR42

https://www.guidetopharmacology.org/GRAC/ObjectDisplayForward?objectId=228 GPR12

https://www.guidetopharmacology.org/GRAC/ObjectDisplayForward?objectId=86 GPR15

https://www.guidetopharmacology.org/GRAC/ObjectDisplayForward?objectId=87 GPR17

https://www.guidetopharmacology.org/GRAC/ObjectDisplayForward?objectId=88 GPR19

https://www.guidetopharmacology.org/GRAC/ObjectDisplayForward?objectId=90 GPR20

https://www.guidetopharmacology.org/GRAC/ObjectDisplayForward?objectId=91 GPR21

https://www.guidetopharmacology.org/GRAC/ObjectDisplayForward?objectId=92 GPR22

https://www.guidetopharmacology.org/GRAC/ObjectDisplayForward?objectId=93 GPR25

https://www.guidetopharmacology.org/GRAC/ObjectDisplayForward?objectId=95 GPR26

https://www.guidetopharmacology.org/GRAC/ObjectDisplayForward?objectId=96 GPR27

https://www.guidetopharmacology.org/GRAC/ObjectDisplayForward?objectId=97 GPR31

https://www.guidetopharmacology.org/GRAC/ObjectDisplayForward?objectId=98 GPR32

https://www.guidetopharmacology.org/GRAC/ObjectDisplayForward?objectId=99 GPR33

https://www.guidetopharmacology.org/GRAC/ObjectDisplayForward?objectId=100 GPR34

https://www.guidetopharmacology.org/GRAC/ObjectDisplayForward?objectId=101 GPR35

https://www.guidetopharmacology.org/GRAC/ObjectDisplayForward?objectId=102 GPR37

https://www.guidetopharmacology.org/GRAC/ObjectDisplayForward?objectId=103 GPR37L1

https://www.guidetopharmacology.org/GRAC/ObjectDisplayForward?objectId=104 GPR39

https://www.guidetopharmacology.org/GRAC/ObjectDisplayForward?objectId=105 GPR45

https://www.guidetopharmacology.org/GRAC/ObjectDisplayForward?objectId=106 GPR50 
https://www.guidetopharmacology.org/GRAC/ObjectDisplayForward?objectId=107 GPR52

https://www.guidetopharmacology.org/GRAC/ObjectDisplayForward?objectId=108 GPR61

https://www.guidetopharmacology.org/GRAC/ObjectDisplayForward?objectId=110 GPR62

https://www.guidetopharmacology.org/GRAC/ObjectDisplayForward?objectId=111 GPR63

https://www.guidetopharmacology.org/GRAC/ObjectDisplayForward?objectId=112 GPR65

https://www.guidetopharmacology.org/GRAC/ObjectDisplayForward?objectId=113 GPR68

https://www.guidetopharmacology.org/GRAC/ObjectDisplayForward?objectId=114 GPR75

https://www.guidetopharmacology.org/GRAC/ObjectDisplayForward?objectId=115 GPR78

https://www.guidetopharmacology.org/GRAC/ObjectDisplayForward?objectId=116 GPR79

https://www.guidetopharmacology.org/GRAC/ObjectDisplayForward?objectId=117 GPR82

https://www.guidetopharmacology.org/GRAC/ObjectDisplayForward?objectId=118 GPR83

https://www.guidetopharmacology.org/GRAC/ObjectDisplayForward?objectId=119 GPR84

https://www.guidetopharmacology.org/GRAC/ObjectDisplayForward?objectId=120 GPR85

https://www.guidetopharmacology.org/GRAC/ObjectDisplayForward?objectId=121 GPR87

https://www.guidetopharmacology.org/GRAC/ObjectDisplayForward?objectId=122 GPR88

https://www.guidetopharmacology.org/GRAC/ObjectDisplayForward?objectId=123 GPR101

https://www.guidetopharmacology.org/GRAC/ObjectDisplayForward?objectId=125 GPR132

https://www.guidetopharmacology.org/GRAC/ObjectDisplayForward?objectId=128 GPR135

https://www.guidetopharmacology.org/GRAC/ObjectDisplayForward?objectId=129 GPR139

https://www.guidetopharmacology.org/GRAC/ObjectDisplayForward?objectId=130 GPR141

https://www.guidetopharmacology.org/GRAC/ObjectDisplayForward?objectId=131 GPR142

https://www.guidetopharmacology.org/GRAC/ObjectDisplayForward?objectId=132 GPR146

https://www.guidetopharmacology.org/GRAC/ObjectDisplayForward?objectId=133 GPR148

https://www.guidetopharmacology.org/GRAC/ObjectDisplayForward?objectId=134 GPR149

https://www.guidetopharmacology.org/GRAC/ObjectDisplayForward?objectId=135 GPR150

https://www.guidetopharmacology.org/GRAC/ObjectDisplayForward?objectId=136 GPR151

https://www.guidetopharmacology.org/GRAC/ObjectDisplayForward?objectId=137 GPR152

https://www.guidetopharmacology.org/GRAC/ObjectDisplayForward?objectId=138 GPR153

https://www.guidetopharmacology.org/GRAC/ObjectDisplayForward?objectId=139 GPR160

https://www.guidetopharmacology.org/GRAC/ObjectDisplayForward?objectId=140 GPR161

https://www.guidetopharmacology.org/GRAC/ObjectDisplayForward?objectId=141 GPR162

https://www.guidetopharmacology.org/GRAC/ObjectDisplayForward?objectId=142 GPR171

https://www.guidetopharmacology.org/GRAC/ObjectDisplayForward?objectId=143 GPR173 
https://www.guidetopharmacology.org/GRAC/ObjectDisplayForward?objectId=144 GPR174

https://www.guidetopharmacology.org/GRAC/ObjectDisplayForward?objectId=145 GPR176

https://www.guidetopharmacology.org/GRAC/ObjectDisplayForward?objectId=637 GPR182

https://www.guidetopharmacology.org/GRAC/ObjectDisplayForward?objectId=146 GPR183

https://www.guidetopharmacology.org/GRAC/ObjectDisplayForward?objectId=81

LGR4

https://www.guidetopharmacology.org/GRAC/ObjectDisplayForward?objectId=147 LGR5

https://www.guidetopharmacology.org/GRAC/ObjectDisplayForward?objectId=148 LGR6

https://www.guidetopharmacology.org/GRAC/ObjectDisplayForward?objectId=149 MAS1

https://www.guidetopharmacology.org/GRAC/ObjectDisplayForward?objectId=150 MAS1L

https://www.guidetopharmacology.org/GRAC/ObjectDisplayForward?objectId=151 $M R G P R D$

https://www.guidetopharmacology.org/GRAC/ObjectDisplayForward?objectId=152 MRGPRE

https://www.guidetopharmacology.org/GRAC/ObjectDisplayForward?objectId=153 $M R G P R F$

https://www.guidetopharmacology.org/GRAC/ObjectDisplayForward?objectId=154 $M R G P R G$

https://www.guidetopharmacology.org/GRAC/ObjectDisplayForward?objectId=155 $M R G P R X 1$

https://www.guidetopharmacology.org/GRAC/ObjectDisplayForward?objectId=156 $M R G P R X 2$

https://www.guidetopharmacology.org/GRAC/ObjectDisplayForward?objectId=157 $M R G P R X 3$

https://www.guidetopharmacology.org/GRAC/ObjectDisplayForward?objectId=158 $M R G P R X 4$

https://www.guidetopharmacology.org/GRAC/ObjectDisplayForward?objectId=159 $P 2 R Y 8$

https://www.guidetopharmacology.org/GRAC/ObjectDisplayForward?objectId=164 P2RY10

https://www.guidetopharmacology.org/GRAC/ObjectDisplayForward?objectId=165 TAAR2

https://www.guidetopharmacology.org/GRAC/ObjectDisplayForward?objectId=167 TAAR3

https://www.guidetopharmacology.org/GRAC/ObjectDisplayForward?objectId=168 TAAR4P

https://www.guidetopharmacology.org/GRAC/ObjectDisplayForward?objectId=169 TAAR5

https://www.guidetopharmacology.org/GRAC/ObjectDisplayForward?objectId=170 TAAR6

https://www.guidetopharmacology.org/GRAC/ObjectDisplayForward?objectId=171 TAARB

https://www.guidetopharmacology.org/GRAC/ObjectDisplayForward?objectId=172 TAAR9

https://www.guidetopharmacology.org/GRAC/ObjectDisplayForward?objectId=173

\section{References}

1. (2006) Retraction. Sphingosylphosphorylcholine is a ligand for ovarian cancer G-protein-coupled receptor 1. Nat Cell Biol 8: 299 [PMID:16508674]

2. Aalto Y, El-Rifa W, Vilpo L, Ollila J, Nagy B, Vihinen M, Vilpo J and Knuutila S. (2001) Distinct gene expression profiling in chronic lymphocytic leukemia with 11q23 deletion. Leukemia 15: 1721-8 [PMID:11681413]

3. Adams F, Grassie M, Shahid M, Hill DR and Henry B. (2003) Acute oral dexamethasone administration reduces levels of orphan GPCR glucocorticoid-induced receptor (GIR) mRNA in rodent brain: potential role in HPA-axis function. Brain Res Mol Brain Res 117: 39-46 [PMID:14499479]

4. Adams JW, Wang J, Davis JR, Liaw C, Gaidarov I, Gatlin J, Dalton ND, Gu Y, Ross J, Behan D, 
Chien K and Connolly D. (2008) Myocardial expression, signaling, and function of GPR22: a protective role for an orphan G protein-coupled receptor. Am J Physiol Heart Circ Physiol 295: H509-21 [PMID:18539757]

5. Adrian K, Bernhard MK, Breitinger HG and Ogilvie A. (2000) Expression of purinergic receptors (ionotropic P2X1-7 and metabotropic P2Y1-11) during myeloid differentiation of HL60 cells. Biochim Biophys Acta 1492: 127-38 [PMID:11004484]

6. Afrasiabi E, Blom T, Ekokoski E, Tuominen RK and Törnquist K. (2006) Sphingosylphosphorylcholine enhances calcium entry in thyroid FRO cells by a mechanism dependent on protein kinase C. Cell Signal 18: 1671-8 [PMID:16490345]

7. Alaerts M, Venken T, Lenaerts AS, De Zutter S, Norrback KF, Adolfsson R and Del-Favero J. (2006) Lack of association of an insertion/deletion polymorphism in the G protein-coupled receptor 50 with bipolar disorder in a Northern Swedish population. Psychiatr Genet 16: 235-6 [PMID:17106423]

8. Albright AV, Shieh JT, Itoh T, Lee B, Pleasure D, O'Connor MJ, Doms RW and González-Scarano F. (1999) Microglia express CCR5, CXCR4, and CCR3, but of these, CCR5 is the principal coreceptor for human immunodeficiency virus type 1 dementia isolates. J Virol 73: 205-13 [PMID:9847323]

9. Alenina N, Bader M and Walther T. (2002) Imprinting of the murine MAS protooncogene is restricted to its antisense RNA. Biochem Biophys Res Commun 290: 1072-8 [PMID:11798184]

10. Alenina N, Baranova T, Smirnow E, Bader M, Lippoldt A, Patkin E and Walther T. (2002) Cell type-specific expression of the Mas proto-oncogene in testis. J Histochem Cytochem 50: 691-6 [PMID:11967280]

11. Ali H. (2016) Mas-related G protein coupled receptor-X2: A potential new target for modulating mast cell-mediated allergic and inflammatory diseases. J Immunobiol 1 [PMID:28090599]

12. Allia E, Tarabra E, Volante M, Cerrato M, Ghigo E, Muccioli G and Papotti M. (2005) Expression of cortistatin and MrgX2, a specific cortistatin receptor, in human neuroendocrine tissues and related tumours. J Pathol 207: 336-45 [PMID:16161007]

13. Amann D, Avidan N, Kanyas K, Kohn Y, Hamdan A, Ben-Asher E, Macciardi F, Beckmann JS, Lancet D and Lerer B. (2006) The trace amine receptor 4 gene is not associated with schizophrenia in a sample linked to chromosome 6q23. Mol Psychiatry 11: 119-21 [PMID:16189505]

14. Ambroz C, Clark AJ and Catt KJ. (1991) The mas oncogene enhances angiotensin-induced $[\mathrm{Ca} 2+] \mathrm{i}$ responses in cells with pre-existing angiotensin II receptors. Biochim Biophys Acta 1133: 107-11 [PMID:1721543]

15. Amisten S, Braun OO, Bengtsson A and Erlinge D. (2008) Gene expression profiling for the identification of G-protein coupled receptors in human platelets. Thromb Res 122: 47-57 [PMID:17920662]

16. Amoh Y, Aki R, Hamada Y, Niiyama S, Eshima K, Kawahara K, Sato Y, Tani Y, Hoffman RM and Katsuoka K. (2012) Nestin-positive hair follicle pluripotent stem cells can promote regeneration of impinged peripheral nerve injury. J Dermatol 39: 33-8 [PMID:22098554]

17. An S, Tsai C and Goetzl EJ. (1995) Cloning, sequencing and tissue distribution of two related G protein-coupled receptor candidates expressed prominently in human lung tissue. FEBS Lett 375: 121-4 [PMID:7498459]

18. Aoki K, Sun YJ, Aoki S, Wada K and Wada E. (2002) Cloning, expression, and mapping of a gene that is upregulated in adipose tissue of mice deficient in bombesin receptor subtype-3. Biochem Biophys Res Commun 290: 1282-8 [PMID:11812002]

19. Arumugam S, Thandavarayan RA, Palaniyandi SS, Giridharan VV, Arozal W, Sari FR, Soetikno V, Harima M, Suzuki K and Kodama M et al.. (2012) Candesartan cilexetil protects from cardiac myosin induced cardiotoxicity via reduction of endoplasmic reticulum stress and apoptosis in rats: involvement of ACE2-Ang (1-7)-mas axis. Toxicology 291: 139-45 [PMID:22120037]

20. Assou S, Le Carrour T, Tondeur S, Ström S, Gabelle A, Marty S, Nadal L, Pantesco V, Réme T, Hugnot JP, Gasca S, Hovatta O, Hamamah S, Klein B and De Vos J. (2007) A meta-analysis of human embryonic stem cells transcriptome integrated into a web-based expression atlas. Stem Cells 25: 961-73 [PMID:17204602]

21. Avula LR, Buckinx R, Alpaerts K, Costagliola A, Adriaensen D, Van Nassauw L and Timmermans JP. (2011) The effect of inflammation on the expression and distribution of the MAS-related gene receptors MrgE and MrgF in the murine ileum. Histochem Cell Biol 136: 569-85 [PMID:21912971]

22. Azimi E, Reddy VB and Lerner EA. (2017) Brief communication: MRGPRX2, atopic dermatitis and red man syndrome. Itch (Phila) 2 [PMID:28367504]

23. Azimi E, Reddy VB, Shade KC, Anthony RM, Talbot S, Pereira PJ and Lerner EA. (2016) Dual action of neurokinin-1 antagonists on Mas-related GPCRs. JCI Insight 1: e89362 [PMID:27734033]

24. Bab I, Smoum R, Bradshaw H and Mechoulam R. (2011) Skeletal lipidomics: regulation of bone metabolism by fatty acid amide family. Br J Pharmacol 163: 1441-6 [PMID:21557736] 
25. Baens M, Finalet Ferreiro J, Tousseyn T, Urbankova H, Michaux L, de Leval L, Dierickx D, Wolter P, Sagaert X and Vandenberghe P et al.. (2012) t(X;14)(p11.4;q32.33) is recurrent in marginal zone lymphoma and up-regulates GPR34. Haematologica 97: 184-8 [PMID:22058210]

26. Balabanian K, Lagane B, Infantino S, Chow KY, Harriague J, Moepps B, Arenzana-Seisdedos F, Thelen M and Bachelerie F. (2005) The chemokine SDF-1/CXCL12 binds to and signals through the orphan receptor RDC1 in T lymphocytes. J Biol Chem 280: 35760-6 [PMID:16107333]

27. Bang S, Xie YK, Zhang ZJ, Wang Z, Xu ZZ and Ji RR. (2018) GPR37 regulates macrophage phagocytosis and resolution of inflammatory pain. J Clin Invest 128: 3568-3582 [PMID:30010619]

28. Barker N and Clevers H. (2010) Leucine-rich repeat-containing G-protein-coupled receptors as markers of adult stem cells. Gastroenterology 138: 1681-96 [PMID:20417836]

29. Barrett P, Ivanova E, Graham ES, Ross AW, Wilson D, Plé H, Mercer JG, Ebling FJ, Schuhler S, Dupré SM, Loudon A and Morgan PJ. (2006) Photoperiodic regulation of cellular retinol binding protein, CRBP1 [corrected] and nestin in tanycytes of the third ventricle ependymal layer of the Siberian hamster. J Endocrinol 191: 687-98 [PMID:17170225]

30. Barrowcliffe TW, Gutteridge JM and Dormandy TL. (1975) The effect of fatty-acid autoxidation products on blood coagulation. Thromb Diath Haemorrh 33: 271-7 [PMID:1138422]

31. Bassilana F, Carlson A, DaSilva JA, Grosshans B, Vidal S, Beck V, Wilmeringwetter B, Llamas LA, Showalter TB and Rigollier P et al.. (2014) Target identification for a Hedgehog pathway inhibitor reveals the receptor GPR39. Nat Chem Biol 10: 343-9 [PMID:24633354]

32. Batailler M, Mullier A, Sidibe A, Delagrange P, Prévot V, Jockers R and Migaud M. (2012) Neuroanatomical distribution of the orphan GPR50 receptor in adult sheep and rodent brains. $J$ Neuroendocrinol 24: 798-808 [PMID:22512326]

33. Bates B, Zhang L, Nawoschik S, Kodangattil S, Tseng E, Kopsco D, Kramer A, Shan Q, Taylor N, Johnson J, Sun Y, Chen HM, Blatcher M, Paulsen JE and Pausch MH. (2006) Characterization of Gpr101 expression and G-protein coupling selectivity. Brain Res 1087: 1-14 [PMID:16647048]

34. Bechtold DA, Sidibe A, Saer BR, Li J, Hand LE, Ivanova EA, Darras VM, Dam J, Jockers R and Luckman SM et al.. (2012) A role for the melatonin-related receptor GPR50 in leptin signaling, adaptive thermogenesis, and torpor. Curr Biol 22: 70-7 [PMID:22197240]

35. Becker JA, Befort K, Blad C, Filliol D, Ghate A, Dembele D, Thibault C, Koch M, Muller J, Lardenois A, Poch O and Kieffer BL. (2008) Transcriptome analysis identifies genes with enriched expression in the mouse central extended amygdala. Neuroscience 156: 950-65 [PMID:18786617]

36. Befort K, Filliol D, Ghate A, Darcq E, Matifas A, Muller J, Lardenois A, Thibault C, Dembele D, Le Merrer J, Becker JA, Poch O and Kieffer BL. (2008) Mu-opioid receptor activation induces transcriptional plasticity in the central extended amygdala. Eur J Neurosci 27: 2973-84 [PMID:18588537]

37. Bektas M, Barak LS, Jolly PS, Liu H, Lynch KR, Lacana E, Suhr KB, Milstien S and Spiegel S. (2003) The G protein-coupled receptor GPR4 suppresses ERK activation in a ligand-independent manner. Biochemistry 42: 12181-91 [PMID:14567679]

38. Bender E, Buist A, Jurzak M, Langlois X, Baggerman G, Verhasselt P, Ercken M, Guo HQ, Wintmolders C and Van den Wyngaert I et al.. (2002) Characterization of an orphan G proteincoupled receptor localized in the dorsal root ganglia reveals adenine as a signaling molecule. Proc Natl Acad Sci USA 99: 8573-8 [PMID:12084918]

39. Benned-Jensen T and Rosenkilde MM. (2010) Distinct expression and ligand-binding profiles of two constitutively active GPR17 splice variants. Br J Pharmacol 159: 1092-105 [PMID:20148890]

40. Benned-Jensen T and Rosenkilde MM. (2008) Structural motifs of importance for the constitutive activity of the orphan 7TM receptor EBI2: analysis of receptor activation in the absence of an agonist. Mol Pharmacol 74: 1008-21 [PMID:18628402]

41. Bhatnagar S, Mishra S and Pathak R. (2011) Mining human genome for novel purinergic P2Y receptors: a sequence analysis and molecular modeling approach. J Recept Signal Transduct Res 31: 75-84 [PMID:21142848]

42. Bhattacharyya S, Luan J, Challis B, Keogh J, Montague C, Brennand J, Morten J, Lowenbeim S, Jenkins S, Farooqi IS, Wareham NJ and O'Rahilly S. (2006) Sequence variants in the melatoninrelated receptor gene (GPR50) associate with circulating triglyceride and HDL levels. J Lipid Res 47: 761-6 [PMID:16436372]

43. Bi Y, Dzierba CD, Fink C, Garcia Y, Green M, Han J, Kwon S, Kumi G, Liang Z and Liu Y et al.. (2015) The discovery of potent agonists for GPR88, an orphan GPCR, for the potential treatment of CNS disorders. Bioorg Med Chem Lett 25: 1443-7 [PMID:25754495]

44. Bikkavilli RK, Tsang SY, Tang WM, Sun JX, Ngai SM, Lee SS, Ko WH, Wise H and Cheung WT. (2006) Identification and characterization of surrogate peptide ligand for orphan $\mathrm{G}$ proteincoupled receptor mas using phage-displayed peptide library. Biochem Pharmacol 71: 319-37 [PMID:16336942]

45. Birkenbach M, Josefsen K, Yalamanchili R, Lenoir G and Kieff E. (1993) Epstein-Barr virus- 
induced genes: first lymphocyte-specific G protein-coupled peptide receptors. J Virol 67: 220920 [PMID:8383238]

46. Bjursell M, Gerdin AK, Jönsson M, Surve VV, Svensson L, Huang XF, Törnell J and Bohlooly-Y M. (2006) G protein-coupled receptor 12 deficiency results in dyslipidemia and obesity in mice. Biochem Biophys Res Commun 348: 359-66 [PMID:16887097]

47. Blaak H, Boers PH, Gruters RA, Schuitemaker H, van der Ende ME and Osterhaus AD. (2005) CCR5, GPR15, and CXCR6 are major coreceptors of human immunodeficiency virus type 2 variants isolated from individuals with and without plasma viremia. J Virol 79: 1686-700 [PMID:15650194]

48. Bly M. (2005) Examination of the trace amine-associated receptor 2 (TAAR2). Schizophr Res 80: 367-8 [PMID:15993565]

49. Bläsius R, Weber RG, Lichter P and Ogilvie A. (1998) A novel orphan G protein-coupled receptor primarily expressed in the brain is localized on human chromosomal band 2q21.J Neurochem 70: 1357-65 [PMID:9523551]

50. Boda E, Viganò F, Rosa P, Fumagalli M, Labat-Gest V, Tempia F, Abbracchio MP, Dimou L and Buffo A. (2011) The GPR17 receptor in NG2 expressing cells: Focus on in vivocell maturation and participation in acute trauma and chronic damage. Glia 59: 1958-73 [PMID:21956849]

51. Bodenmüller H and Schaller HC. (1981) Conserved amino acid sequence of a neuropeptide, the head activator, from coelenterates to humans. Nature 293: 579-80 [PMID:7290191]

52. Boehm M, Hepworth D, Loria PM, Norquay LD, Filipski KJ, Chin JE, Cameron KO, Brenner M, Bonnette P and Cabral S et al.. (2013) Chemical Probe Identification Platform for Orphan GPCRs Using Focused Compound Screening: GPR39 as a Case Example. ACS Med Chem Lett 4: 107984 [PMID:24900608]

53. Bogdanov YD, Dale L, King BF, Whittock N and Burnstock G. (1997) Early expression of a novel nucleotide receptor in the neural plate of Xenopus embryos. J Biol Chem 272: 12583-90 [PMID:9139711]

54. Bohnekamp J, Böselt I, Saalbach A, Tönjes A, Kovacs P, Biebermann H, Manvelyan HM, Polte T, Gasperikova D, Lkhagvasuren S, Baier L, Stumvoll M, Römpler H and Schöneberg T. (2010) Involvement of the chemokine-like receptor GPR33 in innate immunity. Biochem Biophys Res Commun 396: 272-7 [PMID:20399748]

55. Bolick DT, Skaflen MD, Johnson LE, Kwon SC, Howatt D, Daugherty A, Ravichandran KS and Hedrick CC. (2009) G2A deficiency in mice promotes macrophage activation and atherosclerosis. Circ Res 104: 318-27 [PMID:19106413]

56. Bolick DT, Whetzel AM, Skaflen M, Deem TL, Lee J and Hedrick CC. (2007) Absence of the G protein-coupled receptor G2A in mice promotes monocyte/endothelial interactions in aorta. Circ Res 100: 572-80 [PMID:17255525]

57. Booden MA, Siderovski DP and Der CJ. (2002) Leukemia-associated Rho guanine nucleotide exchange factor promotes G alpha q-coupled activation of RhoA. Mol Cell Biol 22: 4053-61 [PMID:12024019]

58. Borowsky B, Adham N, Jones KA, Raddatz R, Artymyshyn R, Ogozalek KL, Durkin MM, Lakhlani PP, Bonini JA and Pathirana S et al.. (2001) Trace amines: identification of a family of mammalian G protein-coupled receptors. Proc Natl Acad Sci USA 98: 8966-71 [PMID:11459929]

59. Botelho-Santos GA, Bader M, Alenina N and Santos RA. (2012) Altered regional blood flow distribution in Mas-deficient mice. Ther Adv Cardiovasc Dis 6: 201-11 [PMID:23045193]

60. Bouchard C, Pagé J, Bédard A, Tremblay P and Vallières L. (2007) G protein-coupled receptor 84, a microglia-associated protein expressed in neuroinflammatory conditions. Glia 55: 790-800 [PMID:17390309]

61. Boulay JL, Ionescu MC, Sivasankaran B, Labuhn M, Dolder-Schlienger B, Taylor E, Morin P, Hemmings BA, Lino MM, Jones G, Maier D and Merlo A. (2009) The 10q25.3-26.1 G proteincoupled receptor gene GPR26 is epigenetically silenced in human gliomas. Int J Oncol 35: 112331 [PMID:19787267]

62. Brennan and Thomas et al.. (2007) Transgenic mice containing GPCR5-1 gene disruptions. Patent number: US2007/0074299.

63. Bresnick JN, Skynner HA, Chapman KL, Jack AD, Zamiara E, Negulescu P, Beaumont K, Patel S and McAllister G. (2003) Identification of signal transduction pathways used by orphan $\mathrm{g}$ protein-coupled receptors. Assay Drug Dev Technol 1: 239-49 [PMID:15090189]

64. Brown AJ, Goldsworthy SM, Barnes AA, Eilert MM, Tcheang L, Daniels D, Muir AI, Wigglesworth MJ, Kinghorn I and Fraser NJ et al.. (2003) The Orphan G protein-coupled receptors GPR41 and GPR43 are activated by propionate and other short chain carboxylic acids. J Biol Chem 278: 11312-9 [PMID:12496283]

65. Brown AJ, Jupe S and Briscoe CP. (2005) A family of fatty acid binding receptors. DNA Cell Biol 24: 54-61 [PMID:15684720]

66. Brézillon S, Detheux M, Parmentier M, Hökfelt T and Hurd YL. (2001) Distribution of an orphan G-protein coupled receptor (JP05) mRNA in the human brain. Brain Res 921: 21-30 [PMID:11720708] 
67. Buccioni M, Marucci G, Dal Ben D, Giacobbe D, Lambertucci C, Soverchia L, Thomas A, Volpini $\mathrm{R}$ and Cristalli G. (2011) Innovative functional cAMP assay for studying G protein-coupled receptors: application to the pharmacological characterization of GPR17. Purinergic Signal 7: 463-8 [PMID:21773766]

68. Buneman P, Christie G, Davies JA, Dimitrellou R, Harding SD, Pawson AJ, Sharman JL and Wu Y. (2020) Why data citation isn't working, and what to do about it Database 2020 [PMID:32367113]

69. Bunnemann B, Fuxe K, Metzger R, Mullins J, Jackson TR, Hanley MR and Ganten D. (1990) Autoradiographic localization of mas proto-oncogene mRNA in adult rat brain using in situ hybridization. Neurosci Lett 114: 147-53 [PMID:2203997]

70. Burns JM, Summers BC, Wang Y, Melikian A, Berahovich R, Miao Z, Penfold ME, Sunshine MJ, Littman DR, Kuo CJ, Wei K, McMaster BE, Wright K, Howard MC and Schall TJ. (2006) A novel chemokine receptor for SDF-1 and I-TAC involved in cell survival, cell adhesion, and tumor development. J Exp Med 203: 2201-13 [PMID:16940167]

71. Burstein ES, Ott TR, Feddock M, Ma JN, Fuhs S, Wong S, Schiffer HH, Brann MR and Nash NR. (2006) Characterization of the Mas-related gene family: structural and functional conservation of human and rhesus MrgX receptors. Br J Pharmacol 147: 73-82 [PMID:16284629]

72. Bäck M, Powell WS, Dahlén SE, Drazen JM, Evans JF, Serhan CN, Shimizu T, Yokomizo T and Rovati GE. (2014) Update on leukotriene, lipoxin and oxoeicosanoid receptors: IUPHAR Review 7. Br J Pharmacol 171: 3551-74 [PMID:24588652]

73. Bédard A, Tremblay P, Chernomoretz A and Vallières L. (2007) Identification of genes preferentially expressed by microglia and upregulated during cuprizone-induced inflammation. Glia 55: 777-89 [PMID:17285589]

74. Cahir-McFarland ED, Carter K, Rosenwald A, Giltnane JM, Henrickson SE, Staudt LM and Kieff E. (2004) Role of NF-kappa B in cell survival and transcription of latent membrane protein 1expressing or Epstein-Barr virus latency III-infected cells. J Virol 78: 4108-19 [PMID:15047827]

75. Cai LY, Abe M, Izumi S, Imura M, Yasugi T and Ushijima T. (2007) Identification of PRTFDC1 silencing and aberrant promoter methylation of GPR150, ITGA8 and HOXD11 in ovarian cancers. Life Sci 80: 1458-65 [PMID:17303177]

76. Canals M, Jenkins L, Kellett E and Milligan G. (2006) Up-regulation of the angiotensin II type 1 receptor by the MAS proto-oncogene is due to constitutive activation of Gq/G11 by MAS. J Biol Chem 281: 16757-67 [PMID:16611642]

77. Cantagrel V, Lossi AM, Boulanger S, Depetris D, Mattei MG, Gecz J, Schwartz CE, Van Maldergem L and Villard L. (2004) Disruption of a new X linked gene highly expressed in brain in a family with two mentally retarded males. J Med Genet 41: 736-42 [PMID:15466006]

78. Carmon KS, Gong X, Lin Q, Thomas A and Liu Q. (2011) R-spondins function as ligands of the orphan receptors LGR4 and LGR5 to regulate Wnt/beta-catenin signaling. Proc Natl Acad Sci USA 108: 11452-7 [PMID:21693646]

79. Carter AN, Cole CL, Playle AG, Ramsay EJ and Shervington AA. (2008) GPR26: a marker for primary glioblastoma? Mol Cell Probes 22: 133-7 [PMID:18037267]

80. Cartoni C, Yasumatsu K, Ohkuri T, Shigemura N, Yoshida R, Godinot N, le Coutre J, Ninomiya Y and Damak S. (2010) Taste preference for fatty acids is mediated by GPR40 and GPR120. J Neurosci 30: 8376-82 [PMID:20573884]

81. Castellone RD, Leffler NR, Dong L and Yang LV. (2011) Inhibition of tumor cell migration and metastasis by the proton-sensing GPR4 receptor. Cancer Lett 312: 197-208 [PMID:21917373]

82. Castro CH, Santos RA, Ferreira AJ, Bader M, Alenina N and Almeida AP. (2006) Effects of genetic deletion of angiotensin-(1-7) receptor Mas on cardiac function during ischemia/reperfusion in the isolated perfused mouse heart. Life Sci 80: 264-8 [PMID:17055538]

83. Castro CH, Santos RA, Ferreira AJ, Bader M, Alenina N and Almeida AP. (2005) Evidence for a functional interaction of the angiotensin-(1-7) receptor Mas with AT1 and AT2 receptors in the mouse heart. Hypertension 46: 937-42 [PMID:16157793]

84. Catalán V, Gómez-Ambrosi J, Rotellar F, Silva C, Gil MJ, Rodríguez A, Cienfuegos JA, Salvador J and Frühbeck G. (2007) The obestatin receptor (GPR39) is expressed in human adipose tissue and is down-regulated in obesity-associated type 2 diabetes mellitus. Clin Endocrinol (Oxf) 66 : 598-601 [PMID:17371481]

85. Cavanaugh DJ, Lee H, Lo L, Shields SD, Zylka MJ, Basbaum AI and Anderson DJ. (2009) Distinct subsets of unmyelinated primary sensory fibers mediate behavioral responses to noxious thermal and mechanical stimuli. Proc Natl Acad Sci USA 106: 9075-80 [PMID:19451647]

86. Cebra-Thomas JA, Tsai JY, Pilder SH, Copeland NG, Jenkins NA and Silver LM. (1992) Localization of the Mas proto-oncogene to a densely marked region of mouse chromosome 17 associated with genomic imprinting. Genomics 13: 444-6 [PMID:1612602]

87. Ceruti $S$, Viganò $F$, Boda E, Ferrario $S$, Magni G, Boccazzi M, Rosa $P$, Buffo A and Abbracchio MP. (2011) Expression of the new P2Y-like receptor GPR17 during oligodendrocyte precursor cell maturation regulates sensitivity to ATP-induced death. Glia 59: 363-78 [PMID:21264945]

88. Ceruti S, Villa G, Genovese T, Mazzon E, Longhi R, Rosa P, Bramanti P, Cuzzocrea S and 
Abbracchio MP. (2009) The P2Y-like receptor GPR17 as a sensor of damage and a new potential target in spinal cord injury. Brain 132: 2206-18 [PMID:19528093]

89. Chan SY, Speck RF, Power C, Gaffen SL, Chesebro B and Goldsmith MA. (1999) V3 recombinants indicate a central role for CCR5 as a coreceptor in tissue infection by human immunodeficiency virus type 1.J Virol 73: 2350-8 [PMID:9971818]

90. Chartrel N, Alvear-Perez R, Leprince J, Iturrioz X, Reaux-Le Goazigo A, Audinot V, Chomarat P, Coge F, Nosjean O, Rodriguez M, Galizzi JP, Boutin JA, Vaudry H and Llorens-Cortes C. (2007) Comment on "Obestatin, a peptide encoded by the ghrelin gene, opposes ghrelin's effects on food intake". Science 315: 766; author reply 766 [PMID:17289961]

91. Chaste P, Clement N, Mercati O, Guillaume JL, Delorme R, Botros HG, Pagan C, Périvier S, Scheid I, Nygren G, Anckarsäter H, Rastam M, Ståhlberg O, Gillberg C, Serrano E, Lemière N, Launay JM, Mouren-Simeoni MC, Leboyer M, Gillberg C, Jockers R and Bourgeron T. (2010) Identification of pathway-biased and deleterious melatonin receptor mutants in autism spectrum disorders and in the general population. PLoS ONE 5: e11495 [PMID:20657642]

92. Chen A, Dong L, Leffler NR, Asch AS, Witte ON and Yang LV. (2011) Activation of GPR4 by acidosis increases endothelial cell adhesion through the cAMP/Epac pathway. PLOS ONE 6: e27586 [PMID:22110680]

93. Chen CL, Broom DC, Liu Y, de Nooij JC, Li Z, Cen C, Samad OA, Jessell TM, Woolf CJ and Ma Q. (2006) Runx1 determines nociceptive sensory neuron phenotype and is required for thermal and neuropathic pain. Neuron 49: 365-77 [PMID:16446141]

94. Chen H and Ikeda SR. (2004) Modulation of ion channels and synaptic transmission by a human sensory neuron-specific G-protein-coupled receptor, SNSR4/mrgX1, heterologously expressed in cultured rat neurons. J Neurosci 24: 5044-53 [PMID:15163697]

95. Chen IM, Harvey RC, Mullighan CG, Gastier-Foster J, Wharton W, Kang H, Borowitz MJ, Camitta BM, Carroll AJ and Devidas M et al.. (2012) Outcome modeling with CRLF2, IKZF1, JAK, and minimal residual disease in pediatric acute lymphoblastic leukemia: a Children's Oncology Group study. Blood 119: 3512-22 [PMID:22368272]

96. Chen PH, Chen X, Lin Z, Fang D and He X. (2013) The structural basis of R-spondin recognition by LGR5 and RNF43. Genes Dev 27: 1345-50 [PMID:23756651]

97. Chen Q, Kogan JH, Gross AK, Zhou Y, Walton NM, Shin R, Heusner CL, Miyake S, Tajinda K and Tamura K et al.. (2012) SREB2/GPR85, a schizophrenia risk factor, negatively regulates hippocampal adult neurogenesis and neurogenesis-dependent learning and memory. Eur $J$ Neurosci 36: 2597-608 [PMID:22697179]

98. Chen Y, Wu H, Wang S, Koito H, Li J, Ye F, Hoang J, Escobar SS, Gow A, Arnett HA, Trapp BD, Karandikar NJ, Hsieh J and Lu QR. (2009) The oligodendrocyte-specific G protein-coupled receptor GPR17 is a cell-intrinsic timer of myelination. Nat Neurosci 12: 1398-406 [PMID:19838178]

99. Chiang N, Fredman G, Bäckhed F, Oh SF, Vickery T, Schmidt BA and Serhan CN. (2012) Infection regulates pro-resolving mediators that lower antibiotic requirements. Nature 484: 524-8 [PMID:22538616]

100. Chiellini G, Erba P, Carnicelli V, Manfredi C, Frascarelli S, Ghelardoni S, Mariani G and Zucchi R. (2012) Distribution of exogenous [125I]-3-iodothyronamine in mouse in vivo: relationship with trace amine-associated receptors. J Endocrinol 213: 223-30 [PMID:22442117]

101. Choi JW, Lee SY and Choi Y. (1996) Identification of a putative G protein-coupled receptor induced during activation-induced apoptosis of T cells. Cell Immunol 168: 78-84 [PMID:8599842]

102. Chu X, Shen M, Xie F, Miao XJ, Shou WH, Liu L, Yang PP, Bai YN, Zhang KY and Yang L et al.. (2013) An X chromosome-wide association analysis identifies variants in GPR174 as a risk factor for Graves' disease. J Med Genet 50: 479-85 [PMID:23667180]

103. Chung JJ, Okamoto Y, Coblitz B, Li M, Qiu Y and Shikano S. (2009) PI3K/Akt signalling-mediated protein surface expression sensed by 14-3-3 interacting motif. FEBS J 276: 5547-58 [PMID:19691494]

104. Ciana P, Fumagalli M, Trincavelli ML, Verderio C, Rosa P, Lecca D, Ferrario S, Parravicini C, Capra V, Gelosa P, Guerrini U, Belcredito S, Cimino M, Sironi L, Tremoli E, Rovati GE, Martini C and Abbracchio MP. (2006) The orphan receptor GPR17 identified as a new dual uracil nucleotides/cysteinyl-leukotrienes receptor. EMBO J 25: 4615-27 [PMID:16990797]

105. Cikos S, Gregor P and Koppel J. (2001) Cloning of a novel biogenic amine receptor-like G protein-coupled receptor expressed in human brain. Biochim Biophys Acta 1521: 66-72 [PMID:11690637]

106. Cilliers T, Nhlapo J, Coetzer M, Orlovic D, Ketas T, Olson WC, Moore JP, Trkola A and Morris L. (2003) The CCR5 and CXCR4 coreceptors are both used by human immunodeficiency virus type 1 primary isolates from subtype C. J Virol 77: 4449-56 [PMID:12634405]

107. Cilliers T, Willey S, Sullivan WM, Patience T, Pugach P, Coetzer M, Papathanasopoulos M, Moore JP, Trkola A and Clapham P et al.. (2005) Use of alternate coreceptors on primary cells by two HIV-1 isolates. Virology 339: 136-44 [PMID:15992849] 
108. Clark HF, Gurney AL, Abaya E, Baker K, Baldwin D, Brush J, Chen J, Chow B, Chui C and Crowley C et al.. (2003) The secreted protein discovery initiative (SPDI), a large-scale effort to identify novel human secreted and transmembrane proteins: a bioinformatics assessment. Genome Res 13: 2265-70 [PMID:12975309]

109. Clayton F, Kotler DP, Kuwada SK, Morgan T, Stepan C, Kuang J, Le J and Fantini J. (2001) Gp120-induced Bob/GPR15 activation: a possible cause of human immunodeficiency virus enteropathy. Am J Pathol 159: 1933-9 [PMID:11696454]

110. Codina J, Opyd TS, Powell ZB, Furdui CM, Petrovic S, Penn RB and DuBose TD. (2011) pHdependent regulation of the $\alpha$-subunit of $\mathrm{H}+-\mathrm{K}+$-ATPase (HKa2). Am J Physiol Renal Physiol 301: F536-43 [PMID:21653633]

111. Coetzer M, Nedellec R, Cilliers T, Meyers T, Morris L and Mosier DE. (2011) Extreme genetic divergence is required for coreceptor switching in HIV-1 subtype C. J Acquir Immune Defic Syndr 56: 9-15 [PMID:20921899]

112. Cox PJ, Pitcher T, Trim SA, Bell CH, Qin W and Kinloch RA. (2008) The effect of deletion of the orphan G - protein coupled receptor (GPCR) gene MrgE on pain-like behaviours in mice. Mol Pain 4: 2 [PMID:18197975]

113. Croitoru-Lamoury J, Guillemin GJ, Boussin FD, Mognetti B, Gigout LI, Chéret A, Vaslin B, Le Grand R, Brew BJ and Dormont D. (2003) Expression of chemokines and their receptors in human and simian astrocytes: evidence for a central role of TNF alpha and IFN gamma in CXCR4 and CCR5 modulation. Glia 41: 354-70 [PMID:12555203]

114. Crouch E, Persson A, Chang D and Parghi D. (1991) Surfactant protein D. Increased accumulation in silica-induced pulmonary lipoproteinosis. Am J Pathol 139: 765-76 [PMID:1656758]

115. Crozier RA, Ajit SK, Kaftan EJ and Pausch MH. (2007) MrgD activation inhibits KCNQ/Mcurrents and contributes to enhanced neuronal excitability. J Neurosci 27: 4492-6 [PMID:17442834]

116. da Costa Gonçalves AC, Leite R, Fraga-Silva RA, Pinheiro SV, Reis AB, Reis FM, Touyz RM, Webb RC, Alenina N and Bader $\mathrm{M}$ et al.. (2007) Evidence that the vasodilator angiotensin-(1-7)Mas axis plays an important role in erectile function. Am J Physiol Heart Circ Physiol 293: H2588-96 [PMID:17616753]

117. da Silveira KD, Coelho FM, Vieira AT, Sachs D, Barroso LC, Costa VV, Bretas TL, Bader M, de Sousa LP and da Silva TA et al.. (2010) Anti-inflammatory effects of the activation of the angiotensin-(1-7) receptor, MAS, in experimental models of arthritis. J Immunol 185: 5569-76 [PMID:20935211]

118. Damond F, Benard A, Ruelle J, Alabi A, Kupfer B, Gomes P, Rodes B, Albert J, Böni J and Garson $\mathrm{J}$ et al.. (2008) Quality control assessment of human immunodeficiency virus type 2 (HIV-2) viral load quantification assays: results from an international collaboration on HIV-2 infection in 2006. J Clin Microbiol 46: 2088-91 [PMID:18434556]

119. Daniele S, Lecca D, Trincavelli ML, Ciampi O, Abbracchio MP and Martini C. (2010) Regulation of PC12 cell survival and differentiation by the new P2Y-like receptor GPR17. Cell Signal 22: 697-706 [PMID:20056144]

120. Daniele S, Trincavelli ML, Gabelloni P, Lecca D, Rosa P, Abbracchio MP and Martini C. (2011) Agonist-induced desensitization/resensitization of human G protein-coupled receptor 17: a functional cross-talk between purinergic and cysteinyl-leukotriene ligands. J Pharmacol Exp Ther 338: 559-67 [PMID:21531793]

121. Davenport AP, Alexander SP, Sharman JL, Pawson AJ, Benson HE, Monaghan AE, Liew WC, Mpamhanga CP, Bonner TI and Neubig RR et al.. (2013) International Union of Basic and Clinical Pharmacology. LXXXVIII. G protein-coupled receptor list: recommendations for new pairings with cognate ligands. Pharmacol Rev 65: 967-86 [PMID:23686350]

122. Davenport AP, Bonner TI, Foord SM, Harmar AJ, Neubig RR, Pin JP, Spedding M, Kojima M and Kangawa K. (2005) International Union of Pharmacology. LVI. Ghrelin receptor nomenclature, distribution, and function. Pharmacol Rev 57: 541-6 [PMID:16382107]

123. de Lau W, Barker N, Low TY, Koo BK, Li VS, Teunissen H, Kujala P, Haegebarth A, Peters PJ and van de Wetering $\mathrm{M}$ et al.. (2011) Lgr5 homologues associate with Wnt receptors and mediate Rspondin signalling. Nature 476: 293-7 [PMID:21727895]

124. De Moerlooze L, Williamson J, Liners F, Perret J and Parmentier M. (2000) Cloning and chromosomal mapping of the mouse and human genes encoding the orphan glucocorticoidinduced receptor (GPR83). Cytogenet Cell Genet 90: 146-50 [PMID:11060465]

125. Deng HK, Unutmaz D, KewalRamani VN and Littman DR. (1997) Expression cloning of new receptors used by simian and human immunodeficiency viruses. Nature 388: 296-300 [PMID:9230441]

126. Derwińska K, Bernaciak J, Wiśniowiecka-Kowalnik B, Obersztyn E, Bocian E and Stankiewicz P. (2009) Autistic features with speech delay in a girl with an approximately 1.5-Mb deletion in 6q16.1, including GPR63 and FUT9. Clin Genet 75: 199-202 [PMID:18717687]

127. Dharmadhikari AV, Kang SH, Szafranski P, Person RE, Sampath S, Prakash SK, Bader PI, Phillips JA, Hannig V and Williams M et al.. (2012) Small rare recurrent deletions and reciprocal 
duplications in 2q21.1, including brain-specific ARHGEF4 and GPR148. Hum Mol Genet 21: 3345-55 [PMID:22543972]

128. Dijkman R, van Doorn R, Szuhai K, Willemze R, Vermeer MH and Tensen CP. (2007) Geneexpression profiling and array-based CGH classify CD4+CD56+ hematodermic neoplasm and cutaneous myelomonocytic leukemia as distinct disease entities. Blood 109: 1720-7 [PMID:17068154]

129. DiLuigi A, Weitzman VN, Pace MC, Siano LJ, Maier D and Mehlmann LM. (2008) Meiotic arrest in human oocytes is maintained by a Gs signaling pathway. Biol Reprod 78: 667-72 [PMID:18184921]

130. Dinter J, Mühlhaus J, Wienchol CL, Yi CX, Nürnberg D, Morin S, Grüters A, Köhrle J, Schöneberg $\mathrm{T}$ and Tschöp $\mathrm{M}$ et al.. (2015) Inverse agonistic action of 3-iodothyronamine at the human trace amine-associated receptor 5. PLoS ONE 10: e0117774 [PMID:25706283]

131. Divorty N, Mackenzie AE, Nicklin SA and Milligan G. (2015) G protein-coupled receptor 35: an emerging target in inflammatory and cardiovascular disease. Front Pharmacol 6: 41 [PMID:25805994]

132. Dong L, Li Z, Leffler NR, Asch AS, Chi JT and Yang LV. (2013) Acidosis activation of the protonsensing GPR4 receptor stimulates vascular endothelial cell inflammatory responses revealed by transcriptome analysis. PLoS ONE 8: e61991 [PMID:23613998]

133. Dong X, Han S, Zylka MJ, Simon MI and Anderson DJ. (2001) A diverse family of GPCRs expressed in specific subsets of nociceptive sensory neurons. Cell 106: 619-32 [PMID:11551509]

134. Duan J, Martinez M, Sanders AR, Hou C, Saitou N, Kitano T, Mowry BJ, Crowe RR, Silverman JM and Levinson DF et al.. (2004) Polymorphisms in the trace amine receptor 4 (TRAR4) gene on chromosome 6q23.2 are associated with susceptibility to schizophrenia. Am J Hum Genet 75: 624-38 [PMID:15329799]

135. Duan S, Du J, Xu Y, Xing Q, Wang H, Wu S, Chen Q, Li X, Li X and Shen J et al.. (2006) Failure to find association between TRAR4 and schizophrenia in the Chinese Han population. J Neural Transm 113: 381-5 [PMID:16075187]

136. Dubins JS, Sanchez-Alavez M, Zhukov V, Sanchez-Gonzalez A, Moroncini G, Carvajal-Gonzalez S, Hadcock JR, Bartfai T and Conti B. (2012) Downregulation of GPR83 in the hypothalamic preoptic area reduces core body temperature and elevates circulating levels of adiponectin. Metab Clin Exp 61: 1486-93 [PMID:22560055]

137. Duong CQ, Bared SM, Abu-Khader A, Buechler C, Schmitz A and Schmitz G. (2004) Expression of the lysophospholipid receptor family and investigation of lysophospholipid-mediated responses in human macrophages. Biochim Biophys Acta 1682: 112-9 [PMID:15158762]

138. Dussor G, Zylka MJ, Anderson DJ and McCleskey EW. (2008) Cutaneous sensory neurons expressing the Mrgprd receptor sense extracellular ATP and are putative nociceptors. $J$ Neurophysiol 99: 1581-9 [PMID:18234974]

139. Eberini I, Daniele S, Parravicini C, Sensi C, Trincavelli ML, Martini C and Abbracchio MP. (2011) In silico identification of new ligands for GPR17: a promising therapeutic target for neurodegenerative diseases. J Comput Aided Mol Des 25: 743-52 [PMID:21744154]

140. Eberwine J and Bartfai T. (2011) Single cell transcriptomics of hypothalamic warm sensitive neurons that control core body temperature and fever response Signaling asymmetry and an extension of chemical neuroanatomy. Pharmacol Ther 129: 241-59 [PMID:20970451]

141. Edinger AL, Hoffman TL, Sharron M, Lee B, O'Dowd B and Doms RW. (1998) Use of GPR1, GPR15, and STRL33 as coreceptors by diverse human immunodeficiency virus type 1 and simian immunodeficiency virus envelope proteins. Virology 249: 367-78 [PMID:9791028]

142. Edinger AL, Mankowski JL, Doranz BJ, Margulies BJ, Lee B, Rucker J, Sharron M, Hoffman TL, Berson JF, Zink MC, Hirsch VM, Clements JE and Doms RW. (1997) CD4-independent, CCR5dependent infection of brain capillary endothelial cells by a neurovirulent simian immunodeficiency virus strain. Proc Natl Acad Sci USA 94: 14742-7 [PMID:9405683]

143. Edson MA, Lin YN and Matzuk MM. (2010) Deletion of the novel oocyte-enriched gene, Gpr149, leads to increased fertility in mice. Endocrinology 151: 358-68 [PMID:19887567]

144. Egerod KL, Holst B, Petersen PS, Hansen JB, Mulder J, Hökfelt T and Schwartz TW. (2007) GPR39 splice variants versus antisense gene LYPD1: expression and regulation in gastrointestinal tract, endocrine pancreas, liver, and white adipose tissue. Mol Endocrinol 21: 1685-98 [PMID:17488974]

145. Eggerickx D, Denef JF, Labbe O, Hayashi Y, Refetoff S, Vassart G, Parmentier M and Libert F. (1995) Molecular cloning of an orphan G-protein-coupled receptor that constitutively activates adenylate cyclase. Biochem J 309 ( Pt 3): 837-43 [PMID:7639700]

146. El-Hashim AZ, Renno WM, Raghupathy R, Abduo HT, Akhtar S and Benter IF. (2012) Angiotensin-(1-7) inhibits allergic inflammation, via the MAS1 receptor, through suppression of ERK1/2- and NF-kB-dependent pathways. Br J Pharmacol 166: 1964-76 [PMID:22339213]

147. Elbim C, Monceaux V, Mueller YM, Lewis MG, François S, Diop O, Akarid K, Hurtrel B, Gougerot-Pocidalo MA and Lévy Y et al.. (2008) Early divergence in neutrophil apoptosis 
between pathogenic and nonpathogenic simian immunodeficiency virus infections of nonhuman primates. J Immunol 181: 8613-23 [PMID:19050281]

148. Ellinghaus D, Folseraas T, Holm K, Ellinghaus E, Melum E, Balschun T, Laerdahl JK, Shiryaev A, Gotthardt DN and Weismüller TJ et al.. (2013) Genome-wide association analysis in primary sclerosing cholangitis and ulcerative colitis identifies risk loci at GPR35 and TCF4. Hepatology 58: 1074-83 [PMID:22821403]

149. Engel KM, Schröck K, Teupser D, Holdt LM, Tönjes A, Kern M, Dietrich K, Kovacs P, Krügel U and Scheidt HA et al.. (2011) Reduced food intake and body weight in mice deficient for the G protein-coupled receptor GPR82. PLoS ONE 6: e29400 [PMID:22216272]

150. Engemaier E, Römpler H, Schöneberg T and Schulz A. (2006) Genomic and supragenomic structure of the nucleotide-like G-protein-coupled receptor GPR34. Genomics 87: 254-64 [PMID:16338117]

151. Ensor HM, Schwab C, Russell LJ, Richards SM, Morrison H, Masic D, Jones L, Kinsey SE, Vora AJ and Mitchell CD et al.. (2011) Demographic, clinical, and outcome features of children with acute lymphoblastic leukemia and CRLF2 deregulation: results from the MRC ALL97 clinical trial. Blood 117: 2129-36 [PMID:21106984]

152. Ernst C, Sequeira A, Klempan T, Ernst N, Ffrench-Mullen J and Turecki G. (2007) Confirmation of region-specific patterns of gene expression in the human brain. Neurogenetics 8: 219-24 [PMID:17375343]

153. Esteban V, Heringer-Walther S, Sterner-Kock A, de Bruin R, van den Engel S, Wang Y, Mezzano S, Egido J, Schultheiss HP and Ruiz-Ortega M et al.. (2009) Angiotensin-(1-7) and the g proteincoupled receptor MAS are key players in renal inflammation. PLOS ONE 4: e5406 [PMID:19404405]

154. Evangelou E, Valdes AM, Kerkhof HJ, Styrkarsdottir U, Zhu Y, Meulenbelt I, Lories RJ, Karassa FB, Tylzanowski P and Bos SD et al.. (2011) Meta-analysis of genome-wide association studies confirms a susceptibility locus for knee osteoarthritis on chromosome 7q22. Ann Rheum Dis 70: 349-55 [PMID:21068099]

155. Fallarini S, Magliulo L, Paoletti T, de Lalla C and Lombardi G. (2010) Expression of functional GPR35 in human iNKT cells. Biochem Biophys Res Commun 398: 420-5 [PMID:20599711]

156. Farzan M, Choe H, Martin K, Marcon L, Hofmann W, Karlsson G, Sun Y, Barrett P, Marchand N, Sullivan N, Gerard N, Gerard C and Sodroski J. (1997) Two orphan seven-transmembrane segment receptors which are expressed in CD4-positive cells support simian immunodeficiency virus infection. J Exp Med 186: 405-11 [PMID:9236192]

157. Feng Y, Wigg K, King N, Vetró A, Kiss E, Kapornai K, Mayer L, Gádoros J, Kennedy JL, Kovacs M, Barr CL and International Consortium for Childhood-Onset Mood Disorders. (2007) GPR50 is not associated with childhood-onset mood disorders in a large sample of Hungarian families. Psychiatr Genet 17: 347-50 [PMID:18075476]

158. Fischer A, Zundler S, Atreya R, Rath T, Voskens C, Hirschmann S, López-Posadas R, Watson A, Becker $C$ and Schuler $G$ et al.. (2016) Differential effects of $\alpha 4 \beta 7$ and GPR15 on homing of effector and regulatory T cells from patients with UC to the inflamed gut in vivo. Gut 65: 164264 [PMID:26209553]

159. Fleischer J, Schwarzenbacher K and Breer H. (2007) Expression of trace amine-associated receptors in the Grueneberg ganglion. Chem Senses 32: 623-31 [PMID:17556730]

160. Fleissner D, Frede A, Knott M, Knuschke T, Geffers R, Hansen W, Dobos G, Langhorst J, Buer J and Westendorf AM. (2011) Generation and function of immunosuppressive human and murine CD8+ T cells by transforming growth factor- $\beta$ and retinoic acid. Immunology 134: 82-92 [PMID:21711349]

161. Foord SM, Bonner TI, Neubig RR, Rosser EM, Pin JP, Davenport AP, Spedding M and Harmar AJ. (2005) International Union of Pharmacology. XLVI. G protein-coupled receptor list. Pharmacol Rev 57: 279-88 [PMID:15914470]

162. Foster SR, Hauser AS, Vedel L, Strachan RT, Huang XP, Gavin AC, Shah SD, Nayak AP, Haugaard-Kedström LM and Penn RB et al.. (2019) Discovery of Human Signaling Systems: Pairing Peptides to G Protein-Coupled Receptors. Cell 179: 895-908.e21 [PMID:31675498]

163. Fournier D, Luft FC, Bader M, Ganten D and Andrade-Navarro MA. (2012) Emergence and evolution of the renin-angiotensin-aldosterone system. J Mol Med 90: 495-508 [PMID:22527880]

164. Fraga-Silva RA, Pinheiro SV, Gonçalves AC, Alenina N, Bader M and Santos RA. (2008) The antithrombotic effect of angiotensin-(1-7) involves mas-mediated NO release from platelets. $\mathrm{Mol}$ Med 14: 28-35 [PMID:18026570]

165. Frasch SC, Berry KZ, Fernandez-Boyanapalli R, Jin HS, Leslie C, Henson PM, Murphy RC and Bratton DL. (2008) NADPH oxidase-dependent generation of lysophosphatidylserine enhances clearance of activated and dying neutrophils via G2A.J Biol Chem 283: 33736-49 [PMID:18824544]

166. Frasch SC, Zemski-Berry K, Murphy RC, Borregaard N, Henson PM and Bratton DL. (2007) Lysophospholipids of different classes mobilize neutrophil secretory vesicles and induce redundant signaling through G2A. J Immunol 178: 6540-8 [PMID:17475884] 
167. Fredriksson R, Höglund PJ, Gloriam DE, Lagerström MC and Schiöth HB. (2003) Seven evolutionarily conserved human rhodopsin G protein-coupled receptors lacking close relatives. FEBS Lett 554: 381-8 [PMID:14623098]

168. Frick KK and Bushinsky DA. (2010) Effect of metabolic and respiratory acidosis on intracellular calcium in osteoblasts. Am J Physiol Renal Physiol 299: F418-25 [PMID:20504884]

169. Frick KK, Krieger NS, Nehrke K and Bushinsky DA. (2009) Metabolic acidosis increases intracellular calcium in bone cells through activation of the proton receptor OGR1.J Bone Miner Res 24: 305-13 [PMID:18847331]

170. Friedman RC, Farh KK, Burge CB and Bartel DP. (2009) Most mammalian mRNAs are conserved targets of microRNAs. Genome Res 19: 92-105 [PMID:18955434]

171. Fujii H, Kawai K, Kawamura K, Mizusuna A, Onoda Y, Murachi M, Tanaka T, Endoh T and Nagase H. (2001) Synthesis of optically active TAN-67, a highly selective delta opioid receptor agonist, and investigation of its pharmacological properties. Drug Des Discov 17: 325-30 [PMID:11765135]

172. Fujisawa D, Kashiwakura J, Kita H, Kikukawa Y, Fujitani Y, Sasaki-Sakamoto T, Kuroda K, Nunomura S, Hayama K and Terui T et al.. (2014) Expression of Mas-related gene X2 on mast cells is upregulated in the skin of patients with severe chronic urticaria. J Allergy Clin Immunol 134: 622-633.e9 [PMID:24954276]

173. Fujiwara S, Yamashita Y, Choi YL, Watanabe H, Kurashina K, Soda M, Enomoto M, Hatanaka H, Takada S, Ozawa K and Mano H. (2007) Transforming activity of purinergic receptor P2Y, G protein coupled, 8 revealed by retroviral expression screening. Leuk Lymphoma 48: 978-86 [PMID:17487742]

174. Fukuda H, Ito S, Watari K, Mogi C, Arisawa M, Okajima F, Kurose H and Shuto S. (2016) Identification of a Potent and Selective GPR4 Antagonist as a Drug Lead for the Treatment of Myocardial Infarction. ACS Med Chem Lett 7: 493-7 [PMID:27190599]

175. Fukunaga S, Setoguchi S, Hirasawa A and Tsujimoto G. (2006) Monitoring ligand-mediated internalization of G protein-coupled receptor as a novel pharmacological approach. Life Sci 80: 17-23 [PMID:16978657]

176. Fumagalli M, Daniele S, Lecca D, Lee PR, Parravicini C, Fields RD, Rosa P, Antonucci F, Verderio C and Trincavelli ML et al.. (2011) Phenotypic changes, signaling pathway, and functional correlates of GPR17-expressing neural precursor cells during oligodendrocyte differentiation. J Biol Chem 286: 10593-604 [PMID:21209081]

177. Gagnon L, Leduc M, Thibodeau JF, Zhang MZ, Grouix B, Sarra-Bournet F, Gagnon W, Hince K, Tremblay M and Geerts L et al.. (2018) A Newly Discovered Antifibrotic Pathway Regulated by Two Fatty Acid Receptors: GPR40 and GPR84. Am J Pathol 188: 1132-1148 [PMID:29454750]

178. Gaidarov I, Adams J, Frazer J, Anthony T, Chen X, Gatlin J, Semple G and Unett DJ. (2018) Angiotensin (1-7) does not interact directly with MAS1, but can potently antagonize signaling from the AT1 receptor. Cell Signal 50: 9-24 [PMID:29928987]

179. Gao Y, Kitagawa K, Hiramatsu Y, Kikuchi H, Isobe T, Shimada M, Uchida C, Hattori T, Oda T and Nakayama K et al.. (2006) Up-regulation of GPR48 induced by down-regulation of p27Kip1 enhances carcinoma cell invasiveness and metastasis. Cancer Res 66: 11623-31 [PMID:17178856]

180. Gao Y, Shan ZY, Wang H, Zhang HM and Teng WP. (2009) Inhibitory effect of shRNA targeting GPR48 on invasion and metastasis of human cervical carcinoma cell line HeLa. Ai Zheng 28: 104-7 [PMID:19550120]

181. Gardner J, Wu S, Ling L, Danao J, Li Y, Yeh WC, Tian H and Baribault H. (2012) G-proteincoupled receptor GPR21 knockout mice display improved glucose tolerance and increased insulin response. Biochem Biophys Res Commun 418: 1-5 [PMID:22155242]

182. Gatto D, Paus D, Basten A, Mackay CR and Brink R. (2009) Guidance of B cells by the orphan G protein-coupled receptor EBI2 shapes humoral immune responses. Immunity 31: 259-69 [PMID:19615922]

183. Gatto D, Wood K and Brink R. (2011) EBI2 operates independently of but in cooperation with CXCR5 and CCR7 to direct B cell migration and organization in follicles and the germinal center. J Immunol 187: 4621-8 [PMID:21948984]

184. Gava E, de Castro CH, Ferreira AJ, Colleta H, Melo MB, Alenina N, Bader M, Oliveira LA, Santos RA and Kitten GT. (2012) Angiotensin-(1-7) receptor Mas is an essential modulator of extracellular matrix protein expression in the heart. Regul Pept 175: 30-42 [PMID:22285513]

185. Gembardt F, Grajewski S, Vahl M, Schultheiss HP and Walther T. (2008) Angiotensin metabolites can stimulate receptors of the Mas-related genes family. Mol Cell Biochem 319: 115-23 [PMID:18636314]

186. Geng Y, Xiong D, Mosyak L, Malito DL, Kniazeff J, Chen Y, Burmakina S, Quick M, Bush M and Javitch JA et al.. (2012) Structure and functional interaction of the extracellular domain of human GABA(B) receptor GBR2. Nat Neurosci 15: 970-8 [PMID:22660477]

187. Gerhard DS, Wagner L, Feingold EA, Shenmen CM, Grouse LH, Schuler G, Klein SL, Old S, Rasooly R and Good P et al.. (2004) The status, quality, and expansion of the NIH full-length 
cDNA project: the Mammalian Gene Collection (MGC). Genome Res 14: 2121-7

[PMID:15489334]

188. Gerwins P, Nordstedt C and Fredholm BB. (1990) Characterization of adenosine A1 receptors in intact DDT1 MF-2 smooth muscle cells. Mol Pharmacol 38: 660-6 [PMID:2172773]

189. Gharu L, Ringe R and Bhattacharya J. (2012) Evidence of extended alternate coreceptor usage by HIV-1 clade C envelope obtained from an Indian patient. Virus Res 163: 410-4 [PMID:22086059]

190. Ghate A, Befort K, Becker JA, Filliol D, Bole-Feysot C, Demebele D, Jost B, Koch M and Kieffer BL. (2007) Identification of novel striatal genes by expression profiling in adult mouse brain. Neuroscience 146: 1182-92 [PMID:17395390]

191. Gironacci MM, Adamo HP, Corradi G, Santos RA, Ortiz P and Carretero OA. (2011) Angiotensin (1-7) induces MAS receptor internalization. Hypertension 58: 176-81 [PMID:21670420]

192. Glatt S, Halbauer D, Heindl S, Wernitznig A, Kozina D, Su KC, Puri C, Garin-Chesa P and Sommergruber W. (2008) hGPR87 contributes to viability of human tumor cells. Int J Cancer 122: 2008-16 [PMID:18183596]

193. Glinka A, Dolde C, Kirsch N, Huang YL, Kazanskaya O, Ingelfinger D, Boutros M, Cruciat CM and Niehrs C. (2011) LGR4 and LGR5 are R-spondin receptors mediating Wnt/ $\beta$-catenin and Wnt/PCP signalling. EMBO Rep 12: 1055-61 [PMID:21909076]

194. Gloriam DE, Fredriksson R and Schiöth HB. (2007) The G protein-coupled receptor subset of the rat genome. BMC Genomics 8: 338 [PMID:17892602]

195. Gloriam DE, Schiöth HB and Fredriksson R. (2005) Nine new human Rhodopsin family G-protein coupled receptors: identification, sequence characterisation and evolutionary relationship. Biochim Biophys Acta 1722: 235-46 [PMID:15777626]

196. Gomes I, Aryal DK, Wardman JH, Gupta A, Gagnidze K, Rodriguiz RM, Kumar S, Wetsel WC, Pintar JE and Fricker LD et al.. (2013) GPR171 is a hypothalamic G protein-coupled receptor for BigLEN, a neuropeptide involved in feeding. Proc Natl Acad Sci USA 110: 16211-6 [PMID:24043826]

197. Gomes I, Bobeck EN, Margolis EB, Gupta A, Sierra S, Fakira AK, Fujita W, Müller TD, Müller A and Tschöp $\mathrm{MH}$ et al.. (2016) Identification of GPR83 as the receptor for the neuroendocrine peptide PEN. Sci Signal 9: ra43 [PMID:27117253]

198. Gong X, Carmon KS, Lin Q, Thomas A, Yi J and Liu Q. (2012) LGR6 is a high affinity receptor of R-spondins and potentially functions as a tumor suppressor. PLoS ONE 7: e37137 [PMID:22615920]

199. Grosse J, Tarnow P, Römpler H, Schneider B, Sedlmeier R, Huffstadt U, Korthaus D, Nehls M, Wattler S, Schöneberg T, Biebermann H and Augustin M. (2006) N-ethyl-N-nitrosourea-based generation of mouse models for mutant G protein-coupled receptors. Physiol Genomics 26: 20917 [PMID:16720677]

200. Grünewald E, Kinnell HL, Porteous DJ and Thomson PA. (2009) GPR50 interacts with neuronal NOGO-A and affects neurite outgrowth. Mol Cell Neurosci 42: 363-71 [PMID:19699797]

201. Gubitz AK and Reppert SM. (1999) Assignment of the melatonin-related receptor to human chromosome X (GPR50) and mouse chromosome X (Gpr50). Genomics 55: 248-51 [PMID:9933574]

202. Gugger M, White R, Song S, Waser B, Cescato R, Rivière P and Reubi JC. (2008) GPR87 is an overexpressed G-protein coupled receptor in squamous cell carcinoma of the lung. Dis Markers 24: 41-50 [PMID:18057535]

203. Guimarães GG, Santos SH, Oliveira ML, Pimenta-Velloso EP, Motta DF, Martins AS, Alenina N, Bader M, Santos RA and Campagnole-Santos MJ. (2012) Exercise induces renin-angiotensin system unbalance and high collagen expression in the heart of Mas-deficient mice. Peptides $\mathbf{3 8}$ : 54-61 [PMID:22921883]

204. Guo Y, Zhang W, Giroux C, Cai Y, Ekambaram P, Dilly AK, Hsu A, Zhou S, Maddipati KR and Liu J et al.. (2011) Identification of the orphan G protein-coupled receptor GPR31 as a receptor for 12-(S)-hydroxyeicosatetraenoic acid. J Biol Chem 286: 33832-40 [PMID:21712392]

205. Habtezion A, Nguyen LP, Hadeiba H and Butcher EC. (2016) Leukocyte Trafficking to the Small Intestine and Colon. Gastroenterology 150: 340-54 [PMID:26551552]

206. Hamouda HO, Chen P, Levoye A, Sözer-Topçular N, Daulat AM, Guillaume JL, Ravid R, Savaskan E, Ferry G, Boutin JA, Delagrange P, Jockers R and Maurice P. (2007) Detection of the human GPR50 orphan seven transmembrane protein by polyclonal antibodies mapping different epitopes. J Pineal Res 43: 10-5 [PMID:17614830]

207. Han SK, Dong X, Hwang JI, Zylka MJ, Anderson DJ and Simon MI. (2002) Orphan G proteincoupled receptors MrgA1 and MrgC11 are distinctively activated by RF-amide-related peptides through the Galpha q/11 pathway. Proc Natl Acad Sci USA 99: 14740-5 [PMID:12397184]

208. Hannedouche S, Zhang J, Yi T, Shen W, Nguyen D, Pereira JP, Guerini D, Baumgarten BU, Roggo S and Wen B et al.. (2011) Oxysterols direct immune cell migration via EBI2. Nature 475: 524-7 [PMID:21796212]

209. Hansen W, Loser K, Westendorf AM, Bruder D, Pfoertner S, Siewert C, Huehn J, Beissert S and 
Buer J. (2006) G protein-coupled receptor 83 overexpression in naive CD4+CD25- T cells leads to the induction of Foxp3+ regulatory T cells in vivo. J Immunol 177: 209-15 [PMID:16785516]

210. Hansen W, Westendorf AM, Toepfer T, Mauel S, Geffers R, Gruber AD and Buer J. (2010) Inflammation in vivo is modulated by GPR83 isoform-4 but not GPR83 isoform-1 expression in regulatory T cells. Genes Immun 11: 357-61 [PMID:20200545]

211. Harden TK. (2013) Enigmatic GPCR finds a stimulating drug. Sci Signal 6: pe34 [PMID:24150253]

212. Harrigan MT, Campbell NF and Bourgeois S. (1991) Identification of a gene induced by glucocorticoids in murine T-cells: a potential G protein-coupled receptor. Mol Endocrinol 5: 1331-8 [PMID:1663214]

213. Harrison JK, Barber CM and Lynch KR. (1993) Molecular cloning of a novel rat G-proteincoupled receptor gene expressed prominently in lung, adrenal, and liver. FEBS Lett 318: 17-22 [PMID:8382168]

214. Harvey RC, Mullighan CG, Chen IM, Wharton W, Mikhail FM, Carroll AJ, Kang H, Liu W, Dobbin KK, Smith MA, Carroll WL, Devidas M, Bowman WP, Camitta BM, Reaman GH, Hunger SP, Downing JR and Willman CL. (2010) Rearrangement of CRLF2 is associated with mutation of JAK kinases, alteration of IKZF1, Hispanic/Latino ethnicity, and a poor outcome in pediatric Bprogenitor acute lymphoblastic leukemia. Blood 115: 5312-21 [PMID:20139093]

215. Hase M, Yokomizo T, Shimizu T and Nakamura M. (2008) Characterization of an orphan G protein-coupled receptor, GPR20, that constitutively activates Gi proteins. J Biol Chem 283: 12747-55 [PMID:18347022]

216. Hasegawa H, Lei J, Matsumoto T, Onishi S, Suemori K and Yasukawa M. (2011) Lysophosphatidylcholine enhances the suppressive function of human naturally occurring regulatory T cells through TGF- $\beta$ production. Biochem Biophys Res Commun 415: 526-31 [PMID:22074829]

217. Hata S, Emi Y, Iyanagi T and Osumi T. (1995) cDNA cloning of a putative G protein-coupled receptor from brain. Biochim Biophys Acta 1261: 121-5 [PMID:7893747]

218. Hattori T, Obinata H, Ogawa A, Kishi M, Tatei K, Ishikawa O and Izumi T. (2008) G2A plays proinflammatory roles in human keratinocytes under oxidative stress as a receptor for 9hydroxyoctadecadienoic acid. J Invest Dermatol 128: 1123-33 [PMID:18034171]

219. Hay DL, Walker CS and Poyner DR. (2011) Adrenomedullin and calcitonin gene-related peptide receptors in endocrine-related cancers: opportunities and challenges. Endocr Relat Cancer 18: C1-14 [PMID:21051558]

220. He W, Miao FJ, Lin DC, Schwandner RT, Wang Z, Gao J, Chen JL, Tian H and Ling L. (2004) Citric acid cycle intermediates as ligands for orphan G-protein-coupled receptors. Nature 429: 188-93 [PMID:15141213]

221. Heiber M, Docherty JM, Shah G, Nguyen T, Cheng R, Heng HH, Marchese A, Tsui LC, Shi X and George SR et al.. (1995) Isolation of three novel human genes encoding G protein-coupled receptors. DNA Cell Biol 14: 25-35 [PMID:7832990]

222. Heiber M, Marchese A, Nguyen T, Heng HH, George SR and O'Dowd BF. (1996) A novel human gene encoding a G-protein-coupled receptor (GPR15) is located on chromosome 3. Genomics 32 : 462-5 [PMID:8838812]

223. Heinig M, Petretto E, Wallace C, Bottolo L, Rotival M, Lu H, Li Y, Sarwar R, Langley SR, Bauerfeind A, Hummel O, Lee YA, Paskas S, Rintisch C, Saar K, Cooper J, Buchan R, Gray EE, Cyster JG, Cardiogenics Consortium, Erdmann J, Hengstenberg C, Maouche S, Ouwehand WH, Rice CM, Samani NJ, Schunkert H, Goodall AH, Schulz H, Roider HG, Vingron M, Blankenberg S, Münzel T, Zeller T, Szymczak S, Ziegler A, Tiret L, Smyth DJ, Pravenec M, Aitman TJ, Cambien F, Clayton D, Todd JA, Hubner N and Cook SA. (2010) A trans-acting locus regulates an anti-viral expression network and type 1 diabetes risk. Nature 467: 460-4 [PMID:20827270]

224. Heise CE, O'Dowd BF, Figueroa DJ, Sawyer N, Nguyen T, Im DS, Stocco R, Bellefeuille JN, Abramovitz $M$ and Cheng R et al.. (2000) Characterization of the human cysteinyl leukotriene 2 receptor. J Biol Chem 275: 30531-6 [PMID:10851239]

225. Hellebrand S, Schaller HC and Wittenberger T. (2000) The brain-specific G-protein coupled receptor GPR85 with identical protein sequence in man and mouse maps to human chromosome 7q31. Biochim Biophys Acta 1493: 269-72 [PMID:10978537]

226. Hellebrand S, Wittenberger T, Schaller HC and Hermans-Borgmeyer I. (2001) Gpr85, a novel member of the G-protein coupled receptor family, prominently expressed in the developing mouse cerebral cortex. Brain Res Gene Expr Patterns 1: 13-6 [PMID:15018813]

227. Hennen S, Wang H, Peters L, Merten N, Simon K, Spinrath A, Blättermann S, Akkari R, Schrage $\mathrm{R}$ and Schröder R et al.. (2013) Decoding signaling and function of the orphan G protein-coupled receptor GPR17 with a small-molecule agonist. Sci Signal 6: ra93 [PMID:24150254]

228. Heringer-Walther S, Gembardt F, Perschel FH, Katz N, Schultheiss HP and Walther T. (2012) The genetic deletion of Mas abolishes salt induced hypertension in mice. Eur J Pharmacol 689: 147-53 [PMID:22652430]

229. Hertzberg L, Vendramini E, Ganmore I, Cazzaniga G, Schmitz M, Chalker J, Shiloh R, Iacobucci 
I, Shochat C, Zeligson S, Cario G, Stanulla M, Strehl S, Russell LJ, Harrison CJ, Bornhauser B, Yoda A, Rechavi G, Bercovich D, Borkhardt A, Kempski H, te Kronnie G, Bourquin JP, Domany E and Izraeli S. (2010) Down syndrome acute lymphoblastic leukemia, a highly heterogeneous disease in which aberrant expression of CRLF2 is associated with mutated JAK2: a report from the International BFM Study Group. Blood 115: 1006-17 [PMID:19965641]

230. Hichami A, Datiche F, Ullah S, Liénard F, Chardigny JM, Cattarelli M and Khan NA. (2007) Olfactory discrimination ability and brain expression of c-fos, Gir and Glut1 mRNA are altered in n-3 fatty acid-depleted rats. Behav Brain Res 184: 1-10 [PMID:17686536]

231. Hinckley M, Vaccari S, Horner K, Chen R and Conti M. (2005) The G-protein-coupled receptors GPR3 and GPR12 are involved in cAMP signaling and maintenance of meiotic arrest in rodent oocytes. Dev Biol 287: 249-61 [PMID:16229830]

232. Hirasawa A, Tsumaya K, Awaji T, Katsuma S, Adachi T, Yamada M, Sugimoto Y, Miyazaki S and Tsujimoto G. (2005) Free fatty acids regulate gut incretin glucagon-like peptide-1 secretion through GPR120. Nat Med 11: 90-94 [PMID:15619630]

233. Hirose K, Shimoda N and Kikuchi Y. (2011) Expression patterns of lgr4 and lgr6 during zebrafish development. Gene Expr Patterns 11: 378-83 [PMID:21570488]

234. Hoffmeister-Ullerich SA, Süsens U and Schaller HC. (2004) The orphan G-protein-coupled receptor GPR19 is expressed predominantly in neuronal cells during mouse embryogenesis. Cell Tissue Res 318: 459-63 [PMID:15452705]

235. Holst B, Egerod KL, Jin C, Petersen PS, Østergaard MV, Hald J, Sprinkel AM, Størling J, Mandrup-Poulsen T, Holst JJ, Thams P, Orskov C, Wierup N, Sundler F, Madsen OD and Schwartz TW. (2009) G protein-coupled receptor 39 deficiency is associated with pancreatic islet dysfunction. Endocrinology 150: 2577-85 [PMID:19213833]

236. Holst B, Egerod KL, Schild E, Vickers SP, Cheetham S, Gerlach LO, Storjohann L, Stidsen CE, Jones R, Beck-Sickinger AG and Schwartz TW. (2007) GPR39 signaling is stimulated by zinc ions but not by obestatin. Endocrinology 148: 13-20 [PMID:16959833]

237. Holst B, Holliday ND, Bach A, Elling CE, Cox HM and Schwartz TW. (2004) Common structural basis for constitutive activity of the ghrelin receptor family. J Biol Chem 279: 53806-17 [PMID:15383539]

238. Holst B, Nygaard R, Valentin-Hansen L, Bach A, Engelstoft MS, Petersen PS, Frimurer TM and Schwartz TW. (2010) A conserved aromatic lock for the tryptophan rotameric switch in TM-VI of seven-transmembrane receptors. J Biol Chem 285: 3973-85 [PMID:19920139]

239. Horikawa Y, Oda N, Cox NJ, Li X, Orho-Melander M, Hara M, Hinokio Y, Lindner TH, Mashima $\mathrm{H}$ and Schwarz PE et al.. (2000) Genetic variation in the gene encoding calpain-10 is associated with type 2 diabetes mellitus. Nat Genet 26: 163-75 [PMID:11017071]

240. Hsu SY, Kudo M, Chen T, Nakabayashi K, Bhalla A, van der Spek PJ, van Duin M and Hsueh AJ. (2000) The three subfamilies of leucine-rich repeat-containing G protein-coupled receptors (LGR): identification of LGR6 and LGR7 and the signaling mechanism for LGR7. Mol Endocrinol 14: 1257-71 [PMID:10935549]

241. Hsu SY, Liang SG and Hsueh AJ. (1998) Characterization of two LGR genes homologous to gonadotropin and thyrotropin receptors with extracellular leucine-rich repeats and a $\mathrm{G}$ proteincoupled, seven-transmembrane region. Mol Endocrinol 12: 1830-45 [PMID:9849958]

242. Hu LA, Tang PM, Eslahi NK, Zhou T, Barbosa J and Liu Q. (2009) Identification of surrogate agonists and antagonists for orphan G-protein-coupled receptor GPR139. J Biomol Screen 14: 789-97 [PMID:19525486]

243. Huang CW, Tzeng JN, Chen YJ, Tsai WF, Chen CC and Sun WH. (2007) Nociceptors of dorsal root ganglion express proton-sensing G-protein-coupled receptors. Mol Cell Neurosci 36: 195210 [PMID:17720533]

244. Huang F, Mehta D, Predescu S, Kim KS and Lum H. (2007) A novel lysophospholipid- and pHsensitive receptor, GPR4, in brain endothelial cells regulates monocyte transmigration. Endothelium 14: 25-34 [PMID:17364894]

245. Huang Q, Feng D, Liu K, Wang P, Xiao H, Wang Y, Zhang S and Liu Z. (2014) A medium-chain fatty acid receptor Gpr84 in zebrafish: expression pattern and roles in immune regulation. Dev Comp Immunol 45: 252-8 [PMID:24704214]

246. Huang WC, Swietach P, Vaughan-Jones RD, Ansorge O and Glitsch MD. (2008) Extracellular acidification elicits spatially and temporally distinct Ca2+ signals. Curr Biol 18: 781-5 [PMID:18485712]

247. Huang XP, Karpiak J, Kroeze WK, Zhu H, Chen X, Moy SS, Saddoris KA, Nikolova VD, Farrell MS and Wang S et al.. (2015) Allosteric ligands for the pharmacologically dark receptors GPR68 and GPR65. Nature 527: 477-83 [PMID:26550826]

248. Hänze J, Dittrich K, Dötsch J and Rascher W. (1997) Molecular cloning of a novel human receptor gene with homology to the rat adrenomedullin receptor and high expression in heart and immune system. Biochem Biophys Res Commun 240: 183-8 [PMID:9367907]

249. Ichimonji I, Tomura H, Mogi C, Sato K, Aoki H, Hisada T, Dobashi K, Ishizuka T, Mori M and Okajima F. (2010) Extracellular acidification stimulates IL-6 production and Ca(2+) mobilization 
through proton-sensing OGR1 receptors in human airway smooth muscle cells. Am J Physiol Lung Cell Mol Physiol 299: L567-77 [PMID:20656891]

250. Ichimura A, Hirasawa A, Hara T and Tsujimoto G. (2009) Free fatty acid receptors act as nutrient sensors to regulate energy homeostasis. Prostaglandins Other Lipid Mediat 89: 82-8 [PMID:19460454]

251. Ichimura A, Hirasawa A, Poulain-Godefroy O, Bonnefond A, Hara T, Yengo L, Kimura I, Leloire A, Liu N and Iida K et al.. (2012) Dysfunction of lipid sensor GPR120 leads to obesity in both mouse and human. Nature 483: 350-4 [PMID:22343897]

252. Ignatov A, Hermans-Borgmeyer I and Schaller HC. (2004) Cloning and characterization of a novel G-protein-coupled receptor with homology to galanin receptors. Neuropharmacology 46: 1114-20 [PMID:15111018]

253. Ignatov A, Lintzel J, Hermans-Borgmeyer I, Kreienkamp HJ, Joost P, Thomsen S, Methner A and Schaller HC. (2003) Role of the G-protein-coupled receptor GPR12 as high-affinity receptor for sphingosylphosphorylcholine and its expression and function in brain development. J Neurosci 23: 907-14 [PMID:12574419]

254. Ignatov A, Lintzel J, Kreienkamp HJ and Schaller HC. (2003) Sphingosine-1-phosphate is a highaffinity ligand for the G protein-coupled receptor GPR6 from mouse and induces intracellular $\mathrm{Ca} 2+$ release by activating the sphingosine-kinase pathway. Biochem Biophys Res Commun 311: 329-36 [PMID:14592418]

255. Ignatov A, Robert J, Gregory-Evans C and Schaller HC. (2006) RANTES stimulates Ca2+ mobilization and inositol trisphosphate (IP3) formation in cells transfected with G proteincoupled receptor 75. Br J Pharmacol 149: 490-7 [PMID:17001303]

256. Ikeno Y, Konno N, Cheon SH, Bolchi A, Ottonello S, Kitamoto K and Arioka M. (2005) Secretory phospholipases A2 induce neurite outgrowth in PC12 cells through lysophosphatidylcholine generation and activation of G2A receptor. J Biol Chem 280: 28044-52 [PMID:15927955]

257. Ikubo M, Inoue A, Nakamura S, Jung S, Sayama M, Otani Y, Uwamizu A, Suzuki K, Kishi T and Shuto A et al.. (2015) Structure-Activity Relationships of Lysophosphatidylserine Analogs as Agonists of G-Protein-Coupled Receptors GPR34, P2Y10, and GPR174. J Med Chem 58: 4204-19 [PMID:25970039]

258. Im DS, Heise CE, Nguyen T, O'Dowd BF and Lynch KR. (2001) Identification of a molecular target of psychosine and its role in globoid cell formation. J Cell Biol 153: 429-34 [PMID:11309421]

259. Imai $Y$, Inoue $H$, Kataoka A, Hua-Qin W, Masuda M, Ikeda T, Tsukita K, Soda M, Kodama T, Fuwa T, Honda Y, Kaneko S, Matsumoto S, Wakamatsu K, Ito S, Miura M, Aosaki T, Itohara S and Takahashi R. (2007) Pael receptor is involved in dopamine metabolism in the nigrostriatal system. Neurosci Res 59: 413-25 [PMID:17889953]

260. Imai Y, Soda M, Inoue H, Hattori N, Mizuno Y and Takahashi R. (2001) An unfolded putative transmembrane polypeptide, which can lead to endoplasmic reticulum stress, is a substrate of Parkin. Cell 105: 891-902 [PMID:11439185]

261. Imamachi N, Park GH, Lee H, Anderson DJ, Simon MI, Basbaum AI and Han SK. (2009) TRPV1expressing primary afferents generate behavioral responses to pruritogens via multiple mechanisms. Proc Natl Acad Sci USA 106: 11330-5 [PMID:19564617]

262. Inoue A, Ishiguro J, Kitamura H, Arima N, Okutani M, Shuto A, Higashiyama S, Ohwada T, Arai $\mathrm{H}$ and Makide K et al.. (2012) TGF $\alpha$ shedding assay: an accurate and versatile method for detecting GPCR activation. Nat Methods 9: 1021-9 [PMID:22983457]

263. Isaacman-Beck J, Hermann EA, Yi Y, Ratcliffe SJ, Mulenga J, Allen S, Hunter E, Derdeyn CA and Collman RG. (2009) Heterosexual transmission of human immunodeficiency virus type 1 subtype C: Macrophage tropism, alternative coreceptor use, and the molecular anatomy of CCR5 utilization. J Virol 83: 8208-20 [PMID:19515785]

264. Isberg V, Andersen KB, Bisig C, Dietz GP, Bräuner-Osborne H and Gloriam DE. (2014) Computer-aided discovery of aromatic l- $\alpha$-amino acids as agonists of the orphan $\mathrm{G}$ proteincoupled receptor GPR139. J Chem Inf Model 54: 1553-7 [PMID:24826842]

265. Ishida J, Hashimoto T, Hashimoto Y, Nishiwaki S, Iguchi T, Harada S, Sugaya T, Matsuzaki H, Yamamoto R and Shiota N et al.. (2004) Regulatory roles for APJ, a seven-transmembrane receptor related to angiotensin-type 1 receptor in blood pressure in vivo. J Biol Chem 279: 26274-9 [PMID:15087458]

266. Ishii S, Kihara Y and Shimizu T. (2005) Identification of T cell death-associated gene 8 (TDAG8) as a novel acid sensing G-protein-coupled receptor. J Biol Chem 280: 9083-7 [PMID:15618224]

267. Ishizaka N, Okazaki H, Kurokawa K, Kumada M and Takuwa Y. (1994) Molecular cloning of a novel putative $\mathrm{G}$ protein-coupled receptor from rat aortic smooth muscle. Downregulation of the mRNA level by the cyclic AMP messenger pathway. Biochim Biophys Acta 1218: 173-80 [PMID:8018717]

268. Itagaki K, Barton BE, Murphy TF, Taheri S, Shu P, Huang H and Jordan ML. (2011) Eicosanoidinduced store-operated calcium entry in dendritic cells. J Surg Res 169: 301-10 [PMID:20080257] 
269. Ito J, Ito M, Nambu H, Fujikawa T, Tanaka K, Iwaasa H and Tokita S. (2009) Anatomical and histological profiling of orphan G-protein-coupled receptor expression in gastrointestinal tract of C57BL/6J mice. Cell Tissue Res 338: 257-69 [PMID:19763624]

270. Ivanova EA, Bechtold DA, Dupré SM, Brennand J, Barrett P, Luckman SM and Loudon AS. (2008) Altered metabolism in the melatonin-related receptor (GPR50) knockout mouse. Am J Physiol Endocrinol Metab 294: E176-82 [PMID:17957037]

271. Iwashita M, Makide K, Nonomura T, Misumi Y, Otani Y, Ishida M, Taguchi R, Tsujimoto M, Aoki $\mathrm{J}$ and Arai $\mathrm{H}$ et al.. (2009) Synthesis and evaluation of lysophosphatidylserine analogues as inducers of mast cell degranulation. Potent activities of lysophosphatidylthreonine and its 2deoxy derivative. J Med Chem 52: 5837-63 [PMID:19743861]

272. Jackson TR, Blair LA, Marshall J, Goedert M and Hanley MR. (1988) The mas oncogene encodes an angiotensin receptor. Nature 335: 437-40 [PMID:3419518]

273. Jacobi FK, Broghammer M, Pesch K, Zrenner E, Berger W, Meindl A and Pusch CM. (2000) Physical mapping and exclusion of GPR34 as the causative gene for congenital stationary night blindness type 1. Hum Genet 107: 89-91 [PMID:10982042]

274. Jacobs KA, Collins-Racie LA, Colbert M, Duckett M, Golden-Fleet M, Kelleher K, Kriz R, LaVallie ER, Merberg D and Spaulding V et al.. (1997) A genetic selection for isolating cDNAs encoding secreted proteins. Gene 198: 289-96 [PMID:9370294]

275. Jahnke GD, Miller MJ, Martínez A, Montuenga L and Cuttitta F. (1997) Adrenomedullin expression in the mouse mammary gland: evidence for the mature form in milk. $J$ Mol Endocrinol 19: 279-89 [PMID:9460649]

276. Jaks V, Barker N, Kasper M, van Es JH, Snippert HJ, Clevers H and Toftgård R. (2008) Lgr5 marks cycling, yet long-lived, hair follicle stem cells. Nat Genet 40: 1291-9 [PMID:18849992]

277. Jankowski V, Tölle M, Santos RA, Günthner T, Krause E, Beyermann M, Welker P, Bader M, Pinheiro SV and Sampaio WO et al.. (2011) Angioprotectin: an angiotensin II-like peptide causing vasodilatory effects. FASEB J 25: 2987-95 [PMID:21628446]

278. Jenkins L, Brea J, Smith NJ, Hudson BD, Reilly G, Bryant NJ, Castro M, Loza MI and Milligan G. (2010) Identification of novel species-selective agonists of the G-protein-coupled receptor GPR35 that promote recruitment of $\beta$-arrestin-2 and activate Go13. Biochem J 432: 451-9 [PMID:20919992]

279. Jensen T, Elster L, Nielsen SM, Poda SB, Loechel F, Volbracht C, Klewe IV, David L and Watson SP. (2014) The identification of GPR3 inverse agonist AF64394; the first small molecule inhibitor of GPR3 receptor function. Bioorg Med Chem Lett 24: 5195-8 [PMID:25442311]

280. Jeon J, Kim C, Sun W, Chung H, Park SH and Kim H. (2002) Cloning and localization of rgpr85 encoding rat G-protein-coupled receptor. Biochem Biophys Res Commun 298: 613-8 [PMID:12408996]

281. Jiang C, Parrish NF, Wilen CB, Li H, Chen Y, Pavlicek JW, Berg A, Lu X, Song H and Tilton JC et al.. (2011) Primary infection by a human immunodeficiency virus with atypical coreceptor tropism. J Virol 85: 10669-81 [PMID:21835785]

282. Jiménez N, Calvo A, Martínez A, Rosell D, Cuttitta F and Montuenga LM. (1999) Expression of adrenomedullin and proadrenomedullin $\mathrm{N}$-terminal 20 peptide in human and rat prostate. $J$ Histochem Cytochem 47: 1167-78 [PMID:10449538]

283. Jin C, Decker AM, Huang XP, Gilmour BP, Blough BE, Roth BL, Hu Y, Gill JB and Zhang XP. (2014) Synthesis, pharmacological characterization, and structure-activity relationship studies of small molecular agonists for the orphan GPR88 receptor. ACS Chem Neurosci 5: 576-87 [PMID:24793972]

284. Jin C, Decker AM, Makhijani VH, Besheer J, Darcq E, Kieffer BL and Maitra R. (2018) Discovery of a Potent, Selective, and Brain-Penetrant Small Molecule that Activates the Orphan Receptor GPR88 and Reduces Alcohol Intake. J Med Chem 61: 6748-6758 [PMID:30011199]

285. Jin C, Yin F, Lin M, Li H, Wang Z, Weng J, Liu M, Da Dong X, Qu J and Tu L. (2008) GPR48 regulates epithelial cell proliferation and migration by activating EGFR during eyelid development. Invest Ophthalmol Vis Sci 49: 4245-53 [PMID:18487371]

286. Jin Y, Damaj BB and Maghazachi AA. (2005) Human resting CD16-, CD16+ and IL-2-, IL-12-, IL15- or IFN-alpha-activated natural killer cells differentially respond to sphingosylphosphorylcholine, lysophosphatidylcholine and platelet-activating factor. Eur J Immunol 35: 2699-708 [PMID:16078278]

287. Jockers R, Maurice P, Boutin JA and Delagrange P. (2008) Melatonin receptors, heterodimerization, signal transduction and binding sites: what's new? BrJ Pharmacol 154: 1182-95 [PMID:18493248]

288. Joensuu T, Hämäläinen R, Yuan B, Johnson C, Tegelberg S, Gasparini P, Zelante L, Pirvola U, Pakarinen L and Lehesjoki AE et al.. (2001) Mutations in a novel gene with transmembrane domains underlie Usher syndrome type 3. Am J Hum Genet 69: 673-84 [PMID:11524702]

289. Johansson A, Helou K and Levan G. (1998) Cytogenetic localization of cancer-related genes in the rat and comparative mapping studies in human and mouse. Cytogenet Cell Genet 81: 217-21 [PMID:9730607] 
290. Johnson LE, Elias MS, Bolick DT, Skaflen MD, Green RM and Hedrick CC. (2008) The G proteincoupled receptor G2A: involvement in hepatic lipid metabolism and gallstone formation in mice. Hepatology 48: 1138-48 [PMID:18821587]

291. Jones PG, Nawoschik SP, Sreekumar K, Uveges AJ, Tseng E, Zhang L, Johnson J, He L, Paulsen JE, Bates B and Pausch MH. (2007) Tissue distribution and functional analyses of the constitutively active orphan G protein coupled receptors, GPR26 and GPR78. Biochim Biophys Acta 1770: 890-901 [PMID:17363172]

292. Jonsson L, Ljunggren E, Bremer A, Pedersen C, Landén M, Thuresson K, Giacobini M and Melke J. (2010) Mutation screening of melatonin-related genes in patients with autism spectrum disorders. BMC Med Genomics 3: 10 [PMID:20377855]

293. Junaid MA, Kuizon S, Cardona J, Azher T, Murakami N, Pullarkat RK and Brown WT. (2011) Folic acid supplementation dysregulates gene expression in lymphoblastoid cells--implications in nutrition. Biochem Biophys Res Commun 412: 688-92 [PMID:21867686]

294. Jung BP, Nguyen T, Kolakowski LF, Lynch KR, Heng HH, George SR and O'Dowd BF. (1997) Discovery of a novel human G protein-coupled receptor gene (GPR25) located on chromosome 1. Biochem Biophys Res Commun 230: 69-72 [PMID:9020062]

295. Kabarowski JH, Zhu K, Le LQ, Witte ON and Xu Y. (2001) Lysophosphatidylcholine as a ligand for the immunoregulatory receptor G2A. Science 293: 702-5 [PMID:11474113]

296. Kamohara M, Matsuo A, Takasaki J, Kohda M, Matsumoto M, Matsumoto S, Soga T, Hiyama H, Kobori M and Katou M. (2005) Identification of MrgX2 as a human G-protein-coupled receptor for proadrenomedullin N-terminal peptides. Biochem Biophys Res Commun 330: 1146-52 [PMID:15823563]

297. Kapas S, Catt KJ and Clark AJ. (1995) Cloning and expression of cDNA encoding a rat adrenomedullin receptor. J Biol Chem 270: 25344-7 [PMID:7592696]

298. Kashem SW, Subramanian H, Collington SJ, Magotti P, Lambris JD and Ali H. (2011) G protein coupled receptor specificity for C3a and compound 48/80-induced degranulation in human mast cells: roles of Mas-related genes MrgX1 and MrgX2. Eur J Pharmacol 668: 299-304 [PMID:21741965]

299. Kato S, Matsubara M, Matsuo T, Mohri Y, Kazama I, Hatano R, Umezawa A and Nishimori K. (2006) Leucine-rich repeat-containing G protein-coupled receptor-4 (LGR4, Gpr48) is essential for renal development in mice. Nephron Exp Nephrol 104: e63-75 [PMID:16785743]

300. Kato S, Mohri Y, Matsuo T, Ogawa E, Umezawa A, Okuyama R and Nishimori K. (2007) Eye-open at birth phenotype with reduced keratinocyte motility in LGR4 null mice. FEBS Lett 581: 468590 [PMID:17850793]

301. Kawasawa Y, Kume K, Izumi T and Shimizu T. (2000) Mammalian PSP24s (alpha and beta isoforms) are not responsive to lysophosphatidic acid in mammalian expression systems. Biochem Biophys Res Commun 276: 957-64 [PMID:11027575]

302. Kawasawa Y, Kume K, Nakade S, Haga H, Izumi T and Shimizu T. (2000) Brain-specific expression of novel G-protein-coupled receptors, with homologies to Xenopus PSP24 and human GPR45. Biochem Biophys Res Commun 276: 952-6 [PMID:11027574]

303. Kawasawa Y, McKenzie LM, Hill DP, Bono H, Yanagisawa M, RIKEN GER Group and GSL Members. (2003) G protein-coupled receptor genes in the FANTOM2 database. Genome Res 13: 1466-77 [PMID:12819145]

304. Kelly LM, Pereira JP, Yi T, Xu Y and Cyster JG. (2011) EBI2 guides serial movements of activated B cells and ligand activity is detectable in lymphoid and nonlymphoid tissues. J Immunol 187: 3026-32 [PMID:21844396]

305. Kennedy SP, Sun D, Oleynek JJ, Hoth CF, Kong J and Hill RJ. (1998) Expression of the rat adrenomedullin receptor or a putative human adrenomedullin receptor does not correlate with adrenomedullin binding or functional response. Biochem Biophys Res Commun 244: 832-7 [PMID:9535752]

306. Kerkhof HJ, Lories RJ, Meulenbelt I, Jonsdottir I, Valdes AM, Arp P, Ingvarsson T, Jhamai M, Jonsson H, Stolk L, Thorleifsson G, Zhai G, Zhang F, Zhu Y, van der Breggen R, Carr A, Doherty M, Doherty S, Felson DT, Gonzalez A, Halldorsson BV, Hart DJ, Hauksson VB, Hofman A, Ioannidis JP, Kloppenburg M, Lane NE, Loughlin J, Luyten FP, Nevitt MC, Parimi N, Pols HA, Rivadeneira F, Slagboom EP, Styrkársdóttir U, Tsezou A, van de Putte T, Zmuda J, Spector TD, Stefansson K, Uitterlinden AG and van Meurs JB. (2010) A genome-wide association study identifies an osteoarthritis susceptibility locus on chromosome 7q22. Arthritis Rheum 62: 499510 [PMID:20112360]

307. Kerschner JE, Hong W, Taylor SR, Kerschner JA, Khampang P, Wrege KC and North PE. (2013) A novel model of spontaneous otitis media with effusion (OME) in the Oxgr1 knock-out mouse. Int J Pediatr Otorhinolaryngol 77: 79-84 [PMID:23200873]

308. Kim KS, Ren J, Jiang Y, Ebrahem Q, Tipps R, Cristina K, Xiao YJ, Qiao J, Taylor KL and Lum H et al.. (2005) GPR4 plays a critical role in endothelial cell function and mediates the effects of sphingosylphosphorylcholine. FASEB J 19: 819-21 [PMID:15857892]

309. Kim N, Park WY, Kim JM, Park YS, Lee DH, Park JH, Kim JS, Jung HC and Song IS. (2007) Analysis of Gene Expression Profile of AGS Cells Stimulated by Helicobacter pylori Adhesion. 
Gut Liver 1: 40-8 [PMID:20485657]

310. Kim SJ, Shon BH, Kang JH, Hahm KS, Yoo OJ, Park YS and Lee KK. (1997) Cloning of novel trinucleotide-repeat (CAG) containing genes in mouse brain. Biochem Biophys Res Commun 240: 239-43 [PMID:9367917]

311. Kim SV, Xiang WV, Kwak C, Yang Y, Lin XW, Ota M, Sarpel U, Rifkin DB, Xu R and Littman DR. (2013) GPR15-mediated homing controls immune homeostasis in the large intestine mucosa. Science 340: 1456-9 [PMID:23661644]

312. Kimata JT, Gosink JJ, KewalRamani VN, Rudensey LM, Littman DR and Overbaugh J. (1999) Coreceptor specificity of temporal variants of simian immunodeficiency virus Mne. J Virol 73: 1655-60 [PMID:9882375]

313. Kirby HR, Maguire JJ, Colledge WH and Davenport AP. (2010) International Union of Basic and Clinical Pharmacology. LXXVII. Kisspeptin receptor nomenclature, distribution, and function. Pharmacol Rev 62: 565-78 [PMID:21079036]

314. Kitamura H, Makide K, Shuto A, Ikubo M, Inoue A, Suzuki K, Sato Y, Nakamura S, Otani Y and Ohwada T et al.. (2012) GPR34 is a receptor for lysophosphatidylserine with a fatty acid at the sn-2 position. J Biochem 151: 511-8 [PMID:22343749]

315. Kitao Y, Imai Y, Ozawa K, Kataoka A, Ikeda T, Soda M, Nakimawa K, Kiyama H, Stern DM, Hori O, Wakamatsu K, Ito S, Itohara S, Takahashi R and Ogawa S. (2007) Pael receptor induces death of dopaminergic neurons in the substantia nigra via endoplasmic reticulum stress and dopamine toxicity, which is enhanced under condition of parkin inactivation. Hum Mol Genet 16: 50-60 [PMID:17116640]

316. Kluskens LD, Nelemans SA, Rink R, de Vries L, Meter-Arkema A, Wang Y, Walther T, Kuipers A, Moll GN and Haas M. (2009) Angiotensin-(1-7) with thioether bridge: an angiotensin-converting enzyme-resistant, potent angiotensin-(1-7) analog. J Pharmacol Exp Ther 328: 849-54 [PMID:19038778]

317. Kober P, Bujko M, Olędzki J, Tysarowski A and Siedlecki JA. (2011) Methyl-CpG binding columnbased identification of nine genes hypermethylated in colorectal cancer. Mol Carcinog 50: 84656 [PMID:21438024]

318. Koldehoff M, Zakrzewski JL, Klein-Hitpass L, Beelen DW and Elmaagacli AH. (2008) Gene profiling of growth factor independence 1B gene (Gfi-1B) in leukemic cells. Int J Hematol 87: 3947 [PMID:18224412]

319. Komarova SV, Pereverzev A, Shum JW, Sims SM and Dixon SJ. (2005) Convergent signaling by acidosis and receptor activator of NF-kappaB ligand (RANKL) on the calcium/calcineurin/NFAT pathway in osteoclasts. Proc Natl Acad Sci USA 102: 2643-8 [PMID:15695591]

320. Korstanje R, Desai J, Lazar G, King B, Rollins J, Spurr M, Joseph J, Kadambi S, Li Y, Cherry A, Matteson PG, Paigen B and Millonig JH. (2008) Quantitative trait loci affecting phenotypic variation in the vacuolated lens mouse mutant, a multigenic mouse model of neural tube defects. Physiol Genomics 35: 296-304 [PMID:18796533]

321. Kostenis E. (2004) Novel clusters of receptors for sphingosine-1-phosphate, sphingosylphosphorylcholine, and (lyso)-phosphatidic acid: new receptors for "old" ligands. $J$ Cell Biochem 92: 923-36 [PMID:15258916]

322. Kostenis E, Milligan G, Christopoulos A, Sanchez-Ferrer CF, Heringer-Walther S, Sexton PM, Gembardt F, Kellett E, Martini L and Vanderheyden P et al.. (2005) G-protein-coupled receptor Mas is a physiological antagonist of the angiotensin II type 1 receptor. Circulation 111: 1806-13 [PMID:15809376]

323. Kotarsky K, Boketoft A, Bristulf J, Nilsson NE, Norberg A, Hansson S, Owman C, Sillard R, LeebLundberg LM and Olde B. (2006) Lysophosphatidic acid binds to and activates GPR92, a G protein-coupled receptor highly expressed in gastrointestinal lymphocytes. J Pharmacol Exp Ther 318: 619-28 [PMID:16651401]

324. Kottyan LC, Collier AR, Cao KH, Niese KA, Hedgebeth M, Radu CG, Witte ON, Khurana Hershey GK, Rothenberg ME and Zimmermann N. (2009) Eosinophil viability is increased by acidic pH in a cAMP- and GPR65-dependent manner. Blood 114: 2774-82 [PMID:19641187]

325. Krieger NS and Bushinsky DA. (2011) Pharmacological inhibition of intracellular calcium release blocks acid-induced bone resorption. Am J Physiol Renal Physiol 300: F91-7 [PMID:21048027]

326. Krishnamoorthy S, Recchiuti A, Chiang N, Fredman G and Serhan CN. (2012) Resolvin D1 receptor stereoselectivity and regulation of inflammation and proresolving microRNAs. Am J Pathol 180: 2018-27 [PMID:22449948]

327. Krishnamoorthy S, Recchiuti A, Chiang N, Yacoubian S, Lee CH, Yang R, Petasis NA and Serhan CN. (2010) Resolvin D1 binds human phagocytes with evidence for proresolving receptors. Proc Natl Acad Sci USA 107: 1660-5 [PMID:20080636]

328. Krusche CA, Kroll T, Beier HM and Classen-Linke I. (2007) Expression of leucine-rich repeatcontaining G-protein-coupled receptors in the human cyclic endometrium. Fertil Steril 87: 142837 [PMID:17274992]

329. Ku GM, Pappalardo Z, Luo CC, German MS and McManus MT. (2012) An siRNA screen in pancreatic beta cells reveals a role for Gpr27 in insulin production. PLoS Genet 8: e1002449 
[PMID:22253604]

330. Kuc D, Zgrajka W, Parada-Turska J, Urbanik-Sypniewska T and Turski WA. (2008) Micromolar concentration of kynurenic acid in rat small intestine. Amino Acids 35: 503-5 [PMID:18235993]

331. Kuhmann SE, Madani N, Diop OM, Platt EJ, Morvan J, Müller-Trutwin MC, Barré-Sinoussi F and Kabat D. (2001) Frequent substitution polymorphisms in African green monkey CCR5 cluster at critical sites for infections by simian immunodeficiency virus SIVagm, implying ancient virushost coevolution. J Virol 75: 8449-60 [PMID:11507190]

332. Kumar M, Grammas P, Giacomelli F and Wiener J. (1996) Selective expression of c-mas protooncogene in rat cerebral endothelial cells. Neuroreport 8: 93-6 [PMID:9051759]

333. Kyaw H, Zeng Z, Su K, Fan P, Shell BK, Carter KC and Li Y. (1998) Cloning, characterization, and mapping of human homolog of mouse T-cell death-associated gene. DNA Cell Biol 17: 493500 [PMID:9655242]

334. Labeguere FG, Nwesome GJR, Alvey LJ, Saniere LRM and Fletcher SR. (2013) Novel dihydropyrimidinoisoquinolinones and pharmaceutical compositions thereof for the treatment of inflammatory disorders Patent number: WO2013092791A1.

335. Lambot MA, Mendive F, Laurent P, Van Schoore G, Noël JC, Vanderhaeghen P and Vassart G. (2009) Three-dimensional reconstruction of efferent ducts in wild-type and Lgr4 knock-out mice. Anat Rec (Hoboken) 292: 595-603 [PMID:19301269]

336. Lan H, Vassileva G, Corona A, Liu L, Baker H, Golovko A, Abbondanzo SJ, Hu W, Yang S and Ning Y et al.. (2009) GPR119 is required for physiological regulation of glucagon-like peptide-1 secretion but not for metabolic homeostasis. J Endocrinol 201: 219-30 [PMID:19282326]

337. Langlois AJ, Desrosiers RC, Lewis MG, KewalRamani VN, Littman DR, Zhou JY, Manson K, Wyand MS, Bolognesi DP and Montefiori DC. (1998) Neutralizing antibodies in sera from macaques immunized with attenuated simian immunodeficiency virus. J Virol 72: 6950-5 [PMID:9658152]

338. Lansu K, Karpiak J, Liu J, Huang XP, McCorvy JD, Kroeze WK, Che T, Nagase H, Carroll FI and Jin J et al.. (2017) In silico design of novel probes for the atypical opioid receptor MRGPRX2. Nat Chem Biol 13: 529-536 [PMID:28288109]

339. Lardner A. (2001) The effects of extracellular pH on immune function. J Leukoc Biol 69: 522-30 [PMID:11310837]

340. Lattin JE, Schroder K, Su AI, Walker JR, Zhang J, Wiltshire T, Saijo K, Glass CK, Hume DA, Kellie S and Sweet MJ. (2008) Expression analysis of G Protein-Coupled Receptors in mouse macrophages. Immunome Res 4: 5 [PMID:18442421]

341. LaTulippe E, Satagopan J, Smith A, Scher H, Scardino P, Reuter V and Gerald WL. (2002) Comprehensive gene expression analysis of prostate cancer reveals distinct transcriptional programs associated with metastatic disease. Cancer Res 62: 4499-506 [PMID:12154061]

342. Lautner RQ, Villela DC, Fraga-Silva RA, Silva N, Verano-Braga T, Costa-Fraga F, Jankowski J, Jankowski V, Sousa F and Alzamora A et al.. (2013) Discovery and characterization of alamandine: a novel component of the Renin-Angiotensin system. Circ Res 112: 1104-11 [PMID:23446738]

343. Lauwers E, Landuyt B, Arckens L, Schoofs L and Luyten W. (2006) Obestatin does not activate orphan G protein-coupled receptor GPR39. Biochem Biophys Res Commun 351: 21-5 [PMID:17054911]

344. Le LQ, Kabarowski JH, Weng Z, Satterthwaite AB, Harvill ET, Jensen ER, Miller JF and Witte ON. (2001) Mice lacking the orphan G protein-coupled receptor G2A develop a late-onset autoimmune syndrome. Immunity 14: 561-71 [PMID:11371358]

345. Le LQ, Kabarowski JH, Wong S, Nguyen K, Gambhir SS and Witte ON. (2002) Positron emission tomography imaging analysis of G2A as a negative modifier of lymphoid leukemogenesis initiated by the BCR-ABL oncogene. Cancer Cell 1: 381-91 [PMID:12086852]

346. Lecca D, Trincavelli ML, Gelosa P, Sironi L, Ciana P, Fumagalli M, Villa G, Verderio C, Grumelli C, Guerrini U, Tremoli E, Rosa P, Cuboni S, Martini C, Buffo A, Cimino M and Abbracchio MP. (2008) The recently identified P2Y-like receptor GPR17 is a sensor of brain damage and a new target for brain repair. PLoS ONE 3: e3579 [PMID:18974869]

347. Ledent C, Demeestere I, Blum D, Petermans J, Hämäläinen T, Smits G and Vassart G. (2005) Premature ovarian aging in mice deficient for Gpr3. Proc Natl Acad Sci USA 102: 8922-6 [PMID:15956199]

348. Lee CH. (2012) Resolvins as new fascinating drug candidates for inflammatory diseases. Arch Pharm Res 35: 3-7 [PMID:22297737]

349. Lee CW, Rivera R, Gardell S, Dubin AE and Chun J. (2006) GPR92 as a new G12/13- and Gqcoupled lysophosphatidic acid receptor that increases cAMP, LPA5. J Biol Chem 281: 23589-97 [PMID:16774927]

350. Lee DK, George SR, Cheng R, Nguyen T, Liu Y, Brown M, Lynch KR and O'Dowd BF. (2001) Identification of four novel human G protein-coupled receptors expressed in the brain. Brain Res Mol Brain Res 86: 13-22 [PMID:11165367]

351. Lee DK, Lynch KR, Nguyen T, Im DS, Cheng R, Saldivia VR, Liu Y, Liu IS, Heng HH, Seeman P, 
George SR, O'Dowd BF and Marchese A. (2000) Cloning and characterization of additional members of the G protein-coupled receptor family. Biochim Biophys Acta 1490: 311-23 [PMID:10684976]

352. Lee DK, Nguyen T, Lynch KR, Cheng R, Vanti WB, Arkhitko O, Lewis T, Evans JF, George SR and O'Dowd BF. (2001) Discovery and mapping of ten novel G protein-coupled receptor genes. Gene 275: 83-91 [PMID:11574155]

353. Lee HY, Shin EH and Bae YS. (2006) Sphingosylphosphorylcholine stimulates human monocytederived dendritic cell chemotaxis. Acta Pharmacol Sin 27: 1359-66 [PMID:17007744]

354. Lee J, Hever A, Willhite D, Zlotnik A and Hevezi P. (2005) Effects of RNA degradation on gene expression analysis of human postmortem tissues. FASEB J 19: 1356-8 [PMID:15955843]

355. Lee JE, Hong EJ, Nam HY, Kim JW, Han BG and Jeon JP. (2011) MicroRNA signatures associated with immortalization of EBV-transformed lymphoblastoid cell lines and their clinical traits. Cell Prolif 44: 59-66 [PMID:21199010]

356. Lee MG, Dong X, Liu Q, Patel KN, Choi OH, Vonakis B and Undem BJ. (2008) Agonists of the MAS-related gene (Mrgs) orphan receptors as novel mediators of mast cell-sensory nerve interactions. J Immunol 180: 2251-5 [PMID:18250432]

357. Lee S, Bookout AL, Lee CE, Gautron L, Harper MJ, Elias CF, Lowell BB and Elmquist JK. (2012) Laser-capture microdissection and transcriptional profiling of the dorsomedial nucleus of the hypothalamus. J Comp Neurol 520: 3617-32 [PMID:22473294]

358. Lee Z, Cheng CT, Zhang H, Subler MA, Wu J, Mukherjee A, Windle JJ, Chen CK and Fang X. (2008) Role of LPA4/p2y9/GPR23 in negative regulation of cell motility. Mol Biol Cell 19: 543545 [PMID:18843048]

359. Lembo PM, Grazzini E, Groblewski T, O'Donnell D, Roy MO, Zhang J, Hoffert C, Cao J, Schmidt $\mathrm{R}$ and Pelletier M et al.. (2002) Proenkephalin A gene products activate a new family of sensory neuron--specific GPCRs. Nat Neurosci 5: 201-9 [PMID:11850634]

360. Leng N, Gu G, Simerly RB and Spindel ER. (1999) Molecular cloning and characterization of two putative $\mathrm{G}$ protein-coupled receptors which are highly expressed in the central nervous system. Brain Res Mol Brain Res 69: 73-83 [PMID:10350639]

361. Leung T, Humbert JE, Stauffer AM, Giger KE, Chen H, Tsai HJ, Wang C, Mirshahi T and Robishaw JD. (2008) The orphan G protein-coupled receptor 161 is required for left-right patterning. Dev Biol 323: 31-40 [PMID:18755178]

362. Levoye A, Dam J, Ayoub MA, Guillaume JL, Couturier C, Delagrange P and Jockers R. (2006) The orphan GPR50 receptor specifically inhibits MT1 melatonin receptor function through heterodimerization. EMBO J 25: 3012-23 [PMID:16778767]

363. Lewis BP, Burge CB and Bartel DP. (2005) Conserved seed pairing, often flanked by adenosines, indicates that thousands of human genes are microRNA targets. Cell 120: 15-20 [PMID:15652477]

364. Li H, Wang D, Singh LS, Berk M, Tan H, Zhao Z, Steinmetz R, Kirmani K, Wei G and Xu Y. (2009) Abnormalities in osteoclastogenesis and decreased tumorigenesis in mice deficient for ovarian cancer G protein-coupled receptor 1. PLOS ONE 4: e5705 [PMID:19479052]

365. Li J, Hand LE, Meng QJ, Loudon AS and Bechtold DA. (2011) GPR50 interacts with TIP60 to modulate glucocorticoid receptor signalling. PLoS ONE 6: e23725 [PMID:21858214]

366. Li Q, Estes JD, Duan L, Jessurun J, Pambuccian S, Forster C, Wietgrefe S, Zupancic M, Schacker $\mathrm{T}$ and Reilly C et al.. (2008) Simian immunodeficiency virus-induced intestinal cell apoptosis is the underlying mechanism of the regenerative enteropathy of early infection. J Infect Dis 197: 420-9 [PMID:18199035]

367. Liaw CW and Connolly DT. (2009) Sequence polymorphisms provide a common consensus sequence for GPR41 and GPR42. DNA Cell Biol 28: 555-60 [PMID:19630535]

368. Liberles SD and Buck LB. (2006) A second class of chemosensory receptors in the olfactory epithelium. Nature 442: 645-650 [PMID:16878137]

369. Liebscher I, Müller U, Teupser D, Engemaier E, Engel KM, Ritscher L, Thor D, Sangkuhl K, Ricken A and Wurm A et al.. (2011) Altered immune response in mice deficient for the G proteincoupled receptor GPR34. J Biol Chem 286: 2101-10 [PMID:21097509]

370. Lin G, Murphy SL, Gaulton GN and Hoxie JA. (2005) Modification of a viral envelope glycoprotein cell-cell fusion assay by utilizing plasmid encoded bacteriophage RNA polymerase. J Virol Methods 128: 135-42 [PMID:15941597]

371. Lin KN, Fang SH, Cai BL, Wang XX, Lu YB, Zhang WP and Wei EQ. (2009) [Construction and identification of eukaryotic expression vector of rat GPR17 gene]. Zhejiang Da Xue Xue Bao Yi Xue Ban 38: 584-90 [PMID:20014483]

372. Lin ME, Rivera RR and Chun J. (2012) Targeted deletion of LPA5 identifies novel roles for lysophosphatidic acid signaling in development of neuropathic pain. J Biol Chem 287: 17608-17 [PMID:22461625]

373. Lin $\mathrm{P}$ and Ye RD. (2003) The lysophospholipid receptor G2A activates a specific combination of G proteins and promotes apoptosis. J Biol Chem 278: 14379-86 [PMID:12586833]

374. Lin ZJ, Lu XM, Zhu TJ, Fang YC, Gu QQ and Zhu W. (2008) GPR12 selections of the metabolites 
from an endophytic Streptomyces sp. associated with Cistanches deserticola. Arch Pharm Res 31: 1108-14 [PMID:18806952]

375. Lindfors L, Sundström L, Fröderberg Roth L, Meuller J, Andersson S and Kihlberg J. (2020) Is GPR146 really the receptor for proinsulin C-peptide? Bioorg Med Chem Lett 30: 127208 [PMID:32354568]

376. Liu C, Bonaventure P, Lee G, Nepomuceno D, Kuei C, Wu J, Li Q, Joseph V, Sutton SW and Eckert W et al.. (2015) GPR139, an Orphan Receptor Highly Enriched in the Habenula and Septum, Is Activated by the Essential Amino Acids L-Tryptophan and L-Phenylalanine. Mol Pharmacol 88: 911-25 [PMID:26349500]

377. Liu C, Shi J, Badner JA, Zou H, Qian Y and Gershon ES. (2007) No association of trace amine receptor genes with bipolar disorder. Mol Psychiatry 12: 979-81 [PMID:17957234]

378. Liu C, Yang XV, Wu J, Kuei C, Mani NS, Zhang L, Yu J, Sutton SW, Qin N and Banie H et al.. (2011) Oxysterols direct B-cell migration through EBI2. Nature 475: 519-23 [PMID:21796211]

379. Liu JP, Komachi M, Tomura H, Mogi C, Damirin A, Tobo M, Takano M, Nochi H, Tamoto K, Sato K and Okajima F. (2010) Ovarian cancer G protein-coupled receptor 1-dependent and independent vascular actions to acidic $\mathrm{pH}$ in human aortic smooth muscle cells. Am J Physiol Heart Circ Physiol 299: H731-42 [PMID:20622109]

380. Liu JP, Nakakura T, Tomura H, Tobo M, Mogi C, Wang JQ, He XD, Takano M, Damirin A, Komachi M, Sato K and Okajima F. (2010) Each one of certain histidine residues in G-proteincoupled receptor GPR4 is critical for extracellular proton-induced stimulation of multiple Gprotein-signaling pathways. Pharmacol Res 61: 499-505 [PMID:20211729]

381. Liu P, Lu Y, Liu H, Wen W, Jia D, Wang Y and You M. (2012) Genome-wide association and fine mapping of genetic loci predisposing to colon carcinogenesis in mice. Mol Cancer Res 10: 66-74 [PMID:22127497]

382. Liu Q, Tang Z, Surdenikova L, Kim S, Patel KN, Kim A, Ru F, Guan Y, Weng HJ, Geng Y, Undem BJ, Kollarik M, Chen ZF, Anderson DJ and Dong X. (2009) Sensory neuron-specific GPCR Mrgprs are itch receptors mediating chloroquine-induced pruritus. Cell 139: 1353-65 [PMID:20004959]

383. Liu Y, Yang FC, Okuda T, Dong X, Zylka MJ, Chen CL, Anderson DJ, Kuner R and Ma Q. (2008) Mechanisms of compartmentalized expression of Mrg class G-protein-coupled sensory receptors. J Neurosci 28: 125-32 [PMID:18171930]

384. Lobo MK, Cui Y, Ostlund SB, Balleine BW and Yang XW. (2007) Genetic control of instrumental conditioning by striatopallidal neuron-specific S1P receptor Gpr6. Nat Neurosci 10: 1395-7 [PMID:17934457]

385. Logue SF, Grauer SM, Paulsen J, Graf R, Taylor N, Sung MA, Zhang L, Hughes Z, Pulito VL, Liu F, Rosenzweig-Lipson S, Brandon NJ, Marquis KL, Bates B and Pausch M. (2009) The orphan GPCR, GPR88, modulates function of the striatal dopamine system: a possible therapeutic target for psychiatric disorders? Mol Cell Neurosci 42: 438-47 [PMID:19796684]

386. Loh ED, Broussard SR and Kolakowski LF. (2001) Molecular characterization of a novel glycoprotein hormone G-protein-coupled receptor. Biochem Biophys Res Commun 282: 757-64 [PMID:11401528]

387. Loh ED, Broussard SR, Liu Q, Copeland NG, Gilbert DJ, Jenkins NA and Kolakowski LF. (2000) Chromosomal localization of GPR48, a novel glycoprotein hormone receptor like GPCR, in human and mouse with radiation hybrid and interspecific backcross mapping. Cytogenet Cell Genet 89: 2-5 [PMID:10894923]

388. Lohr JG, Stojanov P, Lawrence MS, Auclair D, Chapuy B, Sougnez C, Cruz-Gordillo P, Knoechel B, Asmann YW and Slager SL et al.. (2012) Discovery and prioritization of somatic mutations in diffuse large B-cell lymphoma (DLBCL) by whole-exome sequencing. Proc Natl Acad Sci USA 109: 3879-84 [PMID:22343534]

389. Lu LF, Gavin MA, Rasmussen JP and Rudensky AY. (2007) G protein-coupled receptor 83 is dispensable for the development and function of regulatory T cells. Mol Cell Biol 27: 8065-72 [PMID:17893329]

390. Luangsay S, Wittamer V, Bondue B, De Henau O, Rouger L, Brait M, Franssen JD, de Nadai P, Huaux F and Parmentier M. (2009) Mouse ChemR23 is expressed in dendritic cell subsets and macrophages, and mediates an anti-inflammatory activity of chemerin in a lung disease model. $J$ Immunol 183: 6489-99 [PMID:19841182]

391. Lucas RJ, Hattar S, Takao M, Berson DM, Foster RG and Yau KW. (2003) Diminished pupillary light reflex at high irradiances in melanopsin-knockout mice. Science 299: 245-7 [PMID:12522249]

392. Ludewick HP, Schwab SG, Albus M, Lerer B, Maier W, Trixler M and Wildenauer DB. (2008) No support for an association with TAAR6 and schizophrenia in a linked population of European ancestry. Psychiatr Genet 18: 208-10 [PMID:18628684]

393. Ludwig MG, Vanek M, Guerini D, Gasser JA, Jones CE, Junker U, Hofstetter H, Wolf RM and Seuwen K. (2003) Proton-sensing G-protein-coupled receptors. Nature 425: 93-8 [PMID:12955148]

394. Lum H, Qiao J, Walter RJ, Huang F, Subbaiah PV, Kim KS and Holian O. (2003) Inflammatory 
stress increases receptor for lysophosphatidylcholine in human microvascular endothelial cells. Am J Physiol Heart Circ Physiol 285: H1786-9 [PMID:12805023]

395. Lundin C, Hjorth L, Behrendtz M, Nordgren A, Palmqvist L, Andersen MK, Biloglav A, Forestier E, Paulsson K and Johansson B. (2012) High frequency of BTG1 deletions in acute lymphoblastic leukemia in children with down syndrome. Genes Chromosomes Cancer 51: 196-206 [PMID:22072402]

396. Luo J, Zhou W, Zhou X, Li D, Weng J, Yi Z, Cho SG, Li C, Yi T, Wu X, Li XY, de Crombrugghe B, Höök M and Liu M. (2009) Regulation of bone formation and remodeling by G-protein-coupled receptor 48. Development 136: 2747-56 [PMID:19605502]

397. Luo W, Wickramasinghe SR, Savitt JM, Griffin JW, Dawson TM and Ginty DD. (2007) A hierarchical NGF signaling cascade controls Ret-dependent and Ret-independent events during development of nonpeptidergic DRG neurons. Neuron 54: 739-54 [PMID:17553423]

398. Lyle R, Watanabe D, te Vruchte D, Lerchner W, Smrzka OW, Wutz A, Schageman J, Hahner L, Davies C and Barlow DP. (2000) The imprinted antisense RNA at the Igf2r locus overlaps but does not imprint Mas1. Nat Genet 25: 19-21 [PMID:10802648]

399. Macintyre DJ, McGhee KA, Maclean AW, Afzal M, Briffa K, Henry B, Thomson PA, Muir WJ and Blackwood DH. (2010) Association of GPR50, an X-linked orphan G protein-coupled receptor, and affective disorder in an independent sample of the Scottish population. Neurosci Lett 475: 169-73 [PMID:20371266]

400. Maekawa A, Balestrieri B, Austen KF and Kanaoka Y. (2009) GPR17 is a negative regulator of the cysteinyl leukotriene 1 receptor response to leukotriene D4. Proc Natl Acad Sci USA 106: 11685-90 [PMID:19561298]

401. Maekawa A, Xing W, Austen KF and Kanaoka Y. (2010) GPR17 regulates immune pulmonary inflammation induced by house dust mites. J Immunol 185: 1846-54 [PMID:20574000]

402. Maekawa F, Quah HM, Tanaka K and Ohki-Hamazaki H. (2004) Leptin resistance and enhancement of feeding facilitation by melanin-concentrating hormone in mice lacking bombesin receptor subtype-3. Diabetes 53: 570-6 [PMID:14988239]

403. Maghazachi AA, Knudsen E, Jin Y, Jenstad M and Chaudhry FA. (2004) D-galactosyl-beta1-1'sphingosine and D-glucosyl-beta1-1'-sphingosine induce human natural killer cell apoptosis. Biochem Biophys Res Commun 320: 810-5 [PMID:15240120]

404. Maguire JJ, Parker WA, Foord SM, Bonner TI, Neubig RR and Davenport AP. (2009) International Union of Pharmacology. LXXII. Recommendations for trace amine receptor nomenclature. Pharmacol Rev 61: 1-8 [PMID:19325074]

405. Mahadevan MS, Baird S, Bailly JE, Shutler GG, Sabourin LA, Tsilfidis C, Neville CE, Narang M and Korneluk RG. (1995) Isolation of a novel G protein-coupled receptor (GPR4) localized to chromosome 19q13.3. Genomics 30: 84-8 [PMID:8595909]

406. Malicki K, Malicka E, Bańbura MW, Niemiałtowski M and Ladyńska A. (1990) Electron microscopy, immune electron microscopy, enzyme immunoassay and immunofluorescent evaluation of rotaviruses isolated from individual calves and piglets. Acta Virol 34: 523-8 [PMID:1983178]

407. Malik L, Kelly NM, Ma JN, Currier EA, Burstein ES and Olsson R. (2009) Discovery of nonpeptidergic MrgX1 and MrgX2 receptor agonists and exploration of an initial SAR using solidphase synthesis. Bioorg Med Chem Lett 19: 1729-32 [PMID:19230660]

408. Malone MH, Wang Z and Distelhorst CW. (2004) The glucocorticoid-induced gene tdag8 encodes a pro-apoptotic $\mathrm{G}$ protein-coupled receptor whose activation promotes glucocorticoidinduced apoptosis. J Biol Chem 279: 52850-9 [PMID:15485889]

409. Maravillas-Montero JL, Burkhardt AM, Hevezi PA, Carnevale CD, Smit MJ and Zlotnik A. (2015) Cutting edge: GPR35/CXCR8 is the receptor of the mucosal chemokine CXCL17. J Immunol 194: 29-33 [PMID:25411203]

410. Marazziti D, Di Pietro C, Golini E, Mandillo S, Matteoni R and Tocchini-Valentini GP. (2009) Macroautophagy of the GPR37 orphan receptor and Parkinson disease-associated neurodegeneration. Autophagy 5: 741-2 [PMID:19398891]

411. Marazziti D, Di Pietro C, Golini E, Mandillo S, Matteoni R and Tocchini-Valentini GP. (2009) Induction of macroautophagy by overexpression of the Parkinson's disease-associated GPR37 receptor. FASEB J 23: 1978-87 [PMID:19218498]

412. Marazziti D, Di Pietro C, Mandillo S, Golini E, Matteoni R and Tocchini-Valentini GP. (2011) Absence of the GPR37/PAEL receptor impairs striatal Akt and ERK2 phosphorylation, DeltaFosB expression, and conditioned place preference to amphetamine and cocaine. FASEB J 25: 207181 [PMID:21372109]

413. Marazziti D, Gallo A, Golini E, Matteoni R and Tocchini-Valentini GP. (1998) Molecular cloning and chromosomal localization of the mouse Gpr37 gene encoding an orphan G-protein-coupled peptide receptor expressed in brain and testis. Genomics 53: 315-24 [PMID:9799598]

414. Marazziti D, Golini E, Gallo A, Lombardi MS, Matteoni R and Tocchini-Valentini GP. (1997) Cloning of GPR37, a gene located on chromosome 7 encoding a putative G-protein-coupled peptide receptor, from a human frontal brain EST library. Genomics 45: 68-77 [PMID:9339362] 
415. Marazziti D, Golini E, Mandillo S, Magrelli A, Witke W, Matteoni R and Tocchini-Valentini GP. (2004) Altered dopamine signaling and MPTP resistance in mice lacking the Parkinson's diseaseassociated GPR37/parkin-associated endothelin-like receptor. Proc Natl Acad Sci USA 101: 10189-94 [PMID:15218106]

416. Marazziti D, Mandillo S, Di Pietro C, Golini E, Matteoni R and Tocchini-Valentini GP. (2007) GPR37 associates with the dopamine transporter to modulate dopamine uptake and behavioral responses to dopaminergic drugs. Proc Natl Acad Sci USA 104: 9846-51 [PMID:17519329]

417. Marchese A, Nguyen T, Malik P, Xu S, Cheng R, Xie Z, Heng HH, George SR, Kolakowski LF and O'Dowd BF. (1998) Cloning genes encoding receptors related to chemoattractant receptors. Genomics 50: 281-6 [PMID:9653656]

418. Marchese A, Sawzdargo M, Nguyen T, Cheng R, Heng HH, Nowak T, Im DS, Lynch KR, George SR and O'dowd BF. (1999) Discovery of three novel orphan G-protein-coupled receptors. Genomics 56: 12-21 [PMID:10036181]

419. Maresca M, Mahfoud R, Garmy N, Kotler DP, Fantini J and Clayton F. (2003) The virotoxin model of HIV-1 enteropathy: involvement of GPR15/Bob and galactosylceramide in the cytopathic effects induced by HIV-1 gp120 in the HT-29-D4 intestinal cell line. J Biomed Sci 10: 156-66 [PMID:12566994]

420. Margulies BJ, Hauer DA and Clements JE. (2001) Identification and comparison of eleven rhesus macaque chemokine receptors. AIDS Res Hum Retroviruses 17: 981-6 [PMID:11461684]

421. Mario EG, Santos SH, Ferreira AV, Bader M, Santos RA and Botion LM. (2012) Angiotensin-(1-7) Mas-receptor deficiency decreases peroxisome proliferator-activated receptor gamma expression in adipocytes. Peptides 33: 174-7 [PMID:22119778]

422. Marsango S, Barki N, Jenkins L, Tobin AB and Milligan G. (2020) Therapeutic validation of an orphan G protein-coupled receptor: The case of GPR84. Br J Pharmacol [PMID:32869860]

423. Martin KA, Grant SG and Hockfield S. (1992) The mas proto-oncogene is developmentally regulated in the rat central nervous system. Brain Res Dev Brain Res 68: 75-82 [PMID:1521325]

424. Martin KA and Hockfield S. (1993) Expression of the mas proto-oncogene in the rat hippocampal formation is regulated by neuronal activity. Brain Res Mol Brain Res 19: 303-9 [PMID:8231733]

425. Martínez A, Elsasser TH, Muro-Cacho C, Moody TW, Miller MJ, Macri CJ and Cuttitta F. (1997) Expression of adrenomedullin and its receptor in normal and malignant human skin: a potential pluripotent role in the integument. Endocrinology 138: 5597-604 [PMID:9389548]

426. Martínez A, Miller MJ, Catt KJ and Cuttitta F. (1997) Adrenomedullin receptor expression in human lung and in pulmonary tumors. J Histochem Cytochem 45: 159-64 [PMID:9016306]

427. Maruyama T, Miyamoto Y, Nakamura T, Tamai Y, Okada H, Sugiyama E, Nakamura T, Itadani H and Tanaka K. (2002) Identification of membrane-type receptor for bile acids (M-BAR). Biochem Biophys Res Commun 298: 714-9 [PMID:12419312]

428. Massart R, Guilloux JP, Mignon V, Sokoloff P and Diaz J. (2009) Striatal GPR88 expression is confined to the whole projection neuron population and is regulated by dopaminergic and glutamatergic afferents. Eur J Neurosci 30: 397-414 [PMID:19656174]

429. Matsumoto M, Beltaifa S, Weickert CS, Herman MM, Hyde TM, Saunders RC, Lipska BK, Weinberger DR and Kleinman JE. (2005) A conserved mRNA expression profile of SREB2 (GPR85) in adult human, monkey, and rat forebrain. Brain Res Mol Brain Res 138: 58-69 [PMID:15893849]

430. Matsumoto M, Saito T, Takasaki J, Kamohara M, Sugimoto T, Kobayashi M, Tadokoro M, Matsumoto S, Ohishi T and Furuichi K. (2000) An evolutionarily conserved G-protein coupled receptor family, SREB, expressed in the central nervous system. Biochem Biophys Res Commun 272: 576-82 [PMID:10833454]

431. Matsumoto M, Straub RE, Marenco S, Nicodemus KK, Matsumoto S, Fujikawa A, Miyoshi S, Shobo M, Takahashi S, Yarimizu J, Yuri M, Hiramoto M, Morita S, Yokota H, Sasayama T, Terai K, Yoshino M, Miyake A, Callicott JH, Egan MF, Meyer-Lindenberg A, Kempf L, Honea R, Vakkalanka RK, Takasaki J, Kamohara M, Soga T, Hiyama H, Ishii H, Matsuo A, Nishimura S, Matsuoka N, Kobori M, Matsushime H, Katoh M, Furuichi K and Weinberger DR. (2008) The evolutionarily conserved G protein-coupled receptor SREB2/GPR85 influences brain size, behavior, and vulnerability to schizophrenia. Proc Natl Acad Sci USA 105: 6133-8 [PMID:18413613]

432. Matsuo A, Matsumoto S, Nagano M, Masumoto KH, Takasaki J, Matsumoto M, Kobori M, Katoh $\mathrm{M}$ and Shigeyoshi Y. (2005) Molecular cloning and characterization of a novel Gq-coupled orphan receptor GPRg1 exclusively expressed in the central nervous system. Biochem Biophys Res Commun 331: 363-9 [PMID:15845401]

433. Matsuzaki S, Ishizuka T, Yamada H, Kamide Y, Hisada T, Ichimonji I, Aoki H, Yatomi M, Komachi $\mathrm{M}$ and Tsurumaki $\mathrm{H}$ et al.. (2011) Extracellular acidification induces connective tissue growth factor production through proton-sensing receptor OGR1 in human airway smooth muscle cells. Biochem Biophys Res Commun 413: 499-503 [PMID:21907704]

434. Matteson PG, Desai J, Korstanje R, Lazar G, Borsuk TE, Rollins J, Kadambi S, Joseph J, Rahman T, Wink J, Benayed R, Paigen B and Millonig JH. (2008) The orphan G protein-coupled receptor, Gpr161, encodes the vacuolated lens locus and controls neurulation and lens development. Proc 
Natl Acad Sci USA 105: 2088-93 [PMID:18250320]

435. Mazerbourg S, Bouley DM, Sudo S, Klein CA, Zhang JV, Kawamura K, Goodrich LV, Rayburn H, Tessier-Lavigne M and Hsueh AJ. (2004) Leucine-rich repeat-containing, G protein-coupled receptor 4 null mice exhibit intrauterine growth retardation associated with embryonic and perinatal lethality. Mol Endocrinol 18: 2241-54 [PMID:15192078]

436. McCormick MB, Coulombe PA and Fuchs E. (1991) Sorting out IF networks: consequences of domain swapping on IF recognition and assembly. J Cell Biol 113: 1111-24 [PMID:1710225]

437. McGuire J, Herman JP, Ghosal S, Eaton K, Sallee FR and Sah R. (2009) Acid-sensing by the T cell death-associated gene 8 (TDAG8) receptor cloned from rat brain. Biochem Biophys Res Commun 386: 420-5 [PMID:19501050]

438. McKee KK, Tan CP, Palyha OC, Liu J, Feighner SD, Hreniuk DL, Smith RG, Howard AD and Van der Ploeg LH. (1997) Cloning and characterization of two human G protein-coupled receptor genes (GPR38 and GPR39) related to the growth hormone secretagogue and neurotensin receptors. Genomics 46: 426-34 [PMID:9441746]

439. McNeil BD, Pundir P, Meeker S, Han L, Undem BJ, Kulka M and Dong X. (2015) Identification of a mast-cell-specific receptor crucial for pseudo-allergic drug reactions. Nature 519: 237-41 [PMID:25517090]

440. Meder W, Wendland M, Busmann A, Kutzleb C, Spodsberg N, John H, Richter R, Schleuder D, Meyer M and Forssmann WG. (2003) Characterization of human circulating TIG2 as a ligand for the orphan receptor ChemR23. FEBS Lett 555: 495-9 [PMID:14675762]

441. Mehlmann LM, Saeki Y, Tanaka S, Brennan TJ, Evsikov AV, Pendola FL, Knowles BB, Eppig JJ and Jaffe LA. (2004) The Gs-linked receptor GPR3 maintains meiotic arrest in mammalian oocytes. Science 306: 1947-50 [PMID:15591206]

442. Mendive F, Laurent P, Van Schoore G, Skarnes W, Pochet R and Vassart G. (2006) Defective postnatal development of the male reproductive tract in LGR4 knockout mice. Dev Biol 290: 421-34 [PMID:16406039]

443. Metzger R, Bader M, Ludwig T, Berberich C, Bunnemann B and Ganten D. (1995) Expression of the mouse and rat mas proto-oncogene in the brain and peripheral tissues. FEBS Lett 357: 2732 [PMID:8001672]

444. Meyer RC, Giddens MM, Schaefer SA and Hall RA. (2013) GPR37 and GPR37L1 are receptors for the neuroprotective and glioprotective factors prosaptide and prosaposin. Proc Natl Acad Sci USA 110: 9529-34 [PMID:23690594]

445. Meyer zu Heringdorf D and Jakobs KH. (2007) Lysophospholipid receptors: signalling, pharmacology and regulation by lysophospholipid metabolism. Biochim Biophys Acta 1768: 92340 [PMID:17078925]

446. Milasta S, Pediani J, Appelbe S, Trim S, Wyatt M, Cox P, Fidock M and Milligan G. (2006) Interactions between the Mas-related receptors MrgD and MrgE alter signalling and trafficking of MrgD. Mol Pharmacol 69: 479-91 [PMID:16282220]

447. Miller MJ, Martínez A, Unsworth EJ, Thiele CJ, Moody TW, Elsasser T and Cuttitta F. (1996) Adrenomedullin expression in human tumor cell lines. Its potential role as an autocrine growth factor. J Biol Chem 271: 23345-51 [PMID:8798536]

448. Min KD, Asakura M, Liao Y, Nakamaru K, Okazaki H, Takahashi T, Fujimoto K, Ito S, Takahashi A, Asanuma H, Yamazaki S, Minamino T, Sanada S, Seguchi O, Nakano A, Ando Y, Otsuka T, Furukawa H, Isomura T, Takashima S, Mochizuki N and Kitakaze M. (2010) Identification of genes related to heart failure using global gene expression profiling of human failing myocardium. Biochem Biophys Res Commun 393: 55-60 [PMID:20100464]

449. Miyagi T, Chuang LF, Doi RH, Carlos MP, Torres JV and Chuang RY. (2000) Morphine induces gene expression of CCR5 in human CEMx174 lymphocytes. J Biol Chem 275: 31305-10 [PMID:10887175]

450. Mizushima K, Miyamoto Y, Tsukahara F, Hirai M, Sakaki Y and Ito T. (2000) A novel G-proteincoupled receptor gene expressed in striatum. Genomics 69: 314-21 [PMID:11056049]

451. Moechars D, Depoortere I, Moreaux B, de Smet B, Goris I, Hoskens L, Daneels G, Kass S, Ver Donck L, Peeters T and Coulie B. (2006) Altered gastrointestinal and metabolic function in the GPR39-obestatin receptor-knockout mouse. Gastroenterology 131: 1131-41 [PMID:17030183]

452. Mogi C, Tobo M, Tomura H, Murata N, He XD, Sato K, Kimura T, Ishizuka T, Sasaki T, Sato T, Kihara Y, Ishii S, Harada A and Okajima F. (2009) Involvement of proton-sensing TDAG8 in extracellular acidification-induced inhibition of proinflammatory cytokine production in peritoneal macrophages. J Immunol 182: 3243-51 [PMID:19234222]

453. Mogi C, Tomura H, Tobo M, Wang JQ, Damirin A, Kon J, Komachi M, Hashimoto K, Sato K and Okajima F. (2005) Sphingosylphosphorylcholine antagonizes proton-sensing ovarian cancer Gprotein-coupled receptor 1 (OGR1)-mediated inositol phosphate production and cAMP accumulation. J Pharmacol Sci 99: 160-7 [PMID:16210776]

454. Mohebbi N, Benabbas C, Vidal S, Daryadel A, Bourgeois S, Velic A, Ludwig MG, Seuwen K and Wagner CA. (2012) The proton-activated G protein coupled receptor OGR1 acutely regulates the activity of epithelial proton transport proteins. Cell Physiol Biochem 29: 313-24 
[PMID:22508039]

455. Mohri Y, Kato S, Umezawa A, Okuyama R and Nishimori K. (2008) Impaired hair placode formation with reduced expression of hair follicle-related genes in mice lacking Lgr4. Dev Dyn 237: 2235-42 [PMID:18651655]

456. Mohri Y, Oyama K, Akamatsu A, Kato S and Nishimori K. (2011) Lgr4-deficient mice showed premature differentiation of ureteric bud with reduced expression of Wnt effector Lef1 and Gata3. Dev Dyn 240: 1626-34 [PMID:21523854]

457. Mohri Y, Umezu T, Hidema S, Tomisawa H, Akamatsu A, Kato S, Nawa A and Nishimori K. (2010) Reduced fertility with impairment of early-stage embryos observed in mice lacking Lgr4 in epithelial tissues. Fertil Steril 94: 2878-81 [PMID:20638054]

458. Monnot C, Weber V, Stinnakre J, Bihoreau C, Teutsch B, Corvol P and Clauser E. (1991) Cloning and functional characterization of a novel mas-related gene, modulating intracellular angiotensin II actions. Mol Endocrinol 5: 1477-87 [PMID:1723144]

459. Montpetit A and Sinnett D. (1999) Physical mapping of the G-protein coupled receptor 19 (GPR19) in the chromosome 12p12.3 region frequently rearranged in cancer cells. Hum Genet 105: 162-4 [PMID:10480372]

460. Montuenga LM, Martínez A, Miller MJ, Unsworth EJ and Cuttitta F. (1997) Expression of adrenomedullin and its receptor during embryogenesis suggests autocrine or paracrine modes of action. Endocrinology 138: 440-51 [PMID:8977434]

461. Morita H, Mazerbourg S, Bouley DM, Luo CW, Kawamura K, Kuwabara Y, Baribault H, Tian H and Hsueh AJ. (2004) Neonatal lethality of LGR5 null mice is associated with ankyloglossia and gastrointestinal distension. Mol Cell Biol 24: 9736-43 [PMID:15509778]

462. Mudipalli A, Owen RD and Preston RJ. (2005) The effect of arsenicals on ultraviolet-radiationinduced growth arrest and related signaling events in human keratinocytes. Int J Oncol 27: 76978 [PMID:16077927]

463. Mullighan CG, Collins-Underwood JR, Phillips LA, Loudin MG, Liu W, Zhang J, Ma J, CoustanSmith E, Harvey RC, Willman CL, Mikhail FM, Meyer J, Carroll AJ, Williams RT, Cheng J, Heerema NA, Basso G, Pession A, Pui CH, Raimondi SC, Hunger SP, Downing JR, Carroll WL and Rabin KR. (2009) Rearrangement of CRLF2 in B-progenitor- and Down syndrome-associated acute lymphoblastic leukemia. Nat Genet 41: 1243-6 [PMID:19838194]

464. Murakami M, Shiraishi A, Tabata K and Fujita N. (2008) Identification of the orphan GPCR, $\mathrm{P} 2 \mathrm{Y}(10)$ receptor as the sphingosine-1-phosphate and lysophosphatidic acid receptor. Biochem Biophys Res Commun 371: 707-12 [PMID:18466763]

465. Murakami N, Yokomizo T, Okuno T and Shimizu T. (2004) G2A is a proton-sensing G-proteincoupled receptor antagonized by lysophosphatidylcholine. J Biol Chem 279: 42484-91 [PMID:15280385]

466. Murakami T, Shoji M, Imai Y, Inoue H, Kawarabayashi T, Matsubara E, Harigaya Y, Sasaki A, Takahashi R and Abe K. (2004) Pael-R is accumulated in Lewy bodies of Parkinson's disease. Ann Neurol 55: 439-42 [PMID:14991825]

467. Murata N, Mogi C, Tobo M, Nakakura T, Sato K, Tomura H and Okajima F. (2009) Inhibition of superoxide anion production by extracellular acidification in neutrophils. Cell Immunol 259: 216 [PMID:19539899]

468. Mustata RC, Van Loy T, Lefort A, Libert F, Strollo S, Vassart G and Garcia MI. (2011) Lgr4 is required for Paneth cell differentiation and maintenance of intestinal stem cells ex vivo. EMBO Rep 12: 558-64 [PMID:21508962]

469. Mårtensson UE, Salehi SA, Windahl S, Gomez MF, Swärd K, Daszkiewicz-Nilsson J, Wendt A, Andersson N, Hellstrand P and Grände PO et al.. (2009) Deletion of the G protein-coupled receptor 30 impairs glucose tolerance, reduces bone growth, increases blood pressure, and eliminates estradiol-stimulated insulin release in female mice. Endocrinology 150: 687-98 [PMID:18845638]

470. Mörner A, Björndal A, Albert J, Kewalramani VN, Littman DR, Inoue R, Thorstensson R, Fenyö EM and Björling E. (1999) Primary human immunodeficiency virus type 2 (HIV-2) isolates, like HIV-1 isolates, frequently use CCR5 but show promiscuity in coreceptor usage. J Virol 73: 23439 [PMID:9971817]

471. Müller A, Kleinau G, Piechowski CL, Müller TD, Finan B, Pratzka J, Grüters A, Krude H, Tschöp $\mathrm{M}$ and Biebermann H. (2013) G-protein coupled receptor 83 (GPR83) signaling determined by constitutive and zinc(II)-induced activity. PLoS ONE 8: e53347 [PMID:23335960]

472. Müller A, Leinweber B, Fischer J, Müller TD, Grüters A, Tschöp MH, Knäuper V, Biebermann H and Kleinau G. (2014) The extracellular N-terminal domain of G-protein coupled receptor 83 regulates signaling properties and is an intramolecular inverse agonist. BMC Res Notes 7: 913 [PMID:25516095]

473. Nakahara T, Kuroki T, Ohta E, Kajihata T, Yamada H, Yamanaka M, Hashimoto K, Tsutsumi T, Hirano M and Uchimura H. (2003) Effect of the neurotoxic dose of methamphetamine on gene expression of parkin and Pael-receptors in rat striatum. Parkinsonism Relat Disord 9: 213-9 [PMID:12618056]

474. Nakahata T, Tokumaru K, Ito Y, Ishii N, Setoh M, Shimizu Y, Harasawa T, Aoyama K, Hamada T 
and Kori M et al.. (2018) Design and synthesis of 1-(1-benzothiophen-7-yl)-1H-pyrazole, a novel series of G protein-coupled receptor 52 (GPR52) agonists. Bioorg Med Chem 26: 1598-1608 [PMID:29478803]

475. Nakamichi Y, Wada E, Aoki K, Ohara-Imaizumi M, Kikuta T, Nishiwaki C, Matsushima S, Watanabe T, Wada K and Nagamatsu S. (2004) Functions of pancreatic beta cells and adipocytes in bombesin receptor subtype-3-deficient mice. Biochem Biophys Res Commun 318: 698-703 [PMID:15144894]

476. Nambu H, Fukushima M, Hikichi H, Inoue T, Nagano N, Tahara Y, Nambu T, Ito J, Ogawa Y and Ozaki S et al.. (2011) Characterization of metabolic phenotypes of mice lacking GPR61, an orphan G-protein coupled receptor. Life Sci 89: 765-72 [PMID:21971119]

477. Nath M, Offers M, Hummel M and Seissler J. (2011) Isolation and in vitro expansion of Lgr6positive multipotent hair follicle stem cells. Cell Tissue Res 344: 435-44 [PMID:21484413]

478. Neubig RR. (2010) Mind your salts: when the inactive constituent isn't. Mol Pharmacol 78: 5589 [PMID:20651116]

479. Nguyen LP, Pan J, Dinh TT, Hadeiba H, O'Hara 3rd E, Ebtikar A, Hertweck A, Gökmen MR, Lord GM and Jenner RG et al.. (2015) Role and species-specific expression of colon T cell homing receptor GPR15 in colitis. Nat Immunol 16: 207-13 [PMID:25531831]

480. Niedernberg A, Tunaru S, Blaukat A, Ardati A and Kostenis E. (2003) Sphingosine 1-phosphate and dioleoylphosphatidic acid are low affinity agonists for the orphan receptor GPR63. Cell Signal 15: 435-46 [PMID:12618218]

481. Nii T, Prabhu VV, Ruvolo V, Madhukar N, Zhao R, Mu H, Heese L, Nishida Y, Kojima K and Garnett MJ et al.. (2019) Imipridone ONC212 activates orphan G protein-coupled receptor GPR132 and integrated stress response in acute myeloid leukemia. Leukemia 33: 2805-2816 [PMID:31127149]

482. Nikaido Y, Koyama Y, Yoshikawa Y, Furuya T and Takeda S. (2015) Mutation analysis and molecular modeling for the investigation of ligand-binding modes of GPR84. J Biochem 157: 311-20 [PMID:25425658]

483. No authors listed. (2005) Sphingosylphosphorylcholine and lysophosphatidylcholine are ligands for the G protein-coupled receptor GPR4. (Retraction). J Biol Chem 280: 43280 [PMID:16498716]

484. Noguchi K, Ishii S and Shimizu T. (2003) Identification of p2y9/GPR23 as a novel G proteincoupled receptor for lysophosphatidic acid, structurally distant from the Edg family. J Biol Chem 278: 25600-6 [PMID:12724320]

485. Nothacker HP, Wang Z, Zeng H, Mahata SK, O'Connor DT and Civelli O. (2005) Proadrenomedullin N-terminal peptide and cortistatin activation of MrgX2 receptor is based on a common structural motif. Eur J Pharmacol 519: 191-3 [PMID:16111673]

486. O'Dowd BF, Nguyen T, Jung BP, Marchese A, Cheng R, Heng HH, Kolakowski LF, Lynch KR and George SR. (1997) Cloning and chromosomal mapping of four putative novel human G-proteincoupled receptor genes. Gene 187: 75-81 [PMID:9073069]

487. O'Dowd BF, Nguyen T, Lynch KR, Kolakowski LF, Thompson M, Cheng R, Marchese A, Ng G, Heng HH and George SR. (1996) A novel gene codes for a putative G protein-coupled receptor with an abundant expression in brain. FEBS Lett 394: 325-9 [PMID:8830667]

488. O'Dowd BF, Nguyen T, Marchese A, Cheng R, Lynch KR, Heng HH, Kolakowski Jr LF and George SR. (1998) Discovery of three novel G-protein-coupled receptor genes. Genomics 47: 310-3 [PMID:9479505]

489. Obinata H, Hattori T, Nakane S, Tatei K and Izumi T. (2005) Identification of 9hydroxyoctadecadienoic acid and other oxidized free fatty acids as ligands of the $\mathrm{G}$ proteincoupled receptor G2A. J Biol Chem 280: 40676-83 [PMID:16236715]

490. Ocón B, Pan J, Dinh TT, Chen W, Ballet R, Bscheider M, Habtezion A, Tu H, Zabel BA and Butcher EC. (2017) A Mucosal and Cutaneous Chemokine Ligand for the Lymphocyte Chemoattractant Receptor GPR15. Front Immunol 8: 1111 [PMID:28936214]

491. Offermanns S, Colletti SL, Lovenberg TW, Semple G, Wise A and IJzerman AP. (2011) International Union of Basic and Clinical Pharmacology. LXXXII: Nomenclature and Classification of Hydroxy-carboxylic Acid Receptors (GPR81, GPR109A, and GPR109B). Pharmacol Rev 63: 269-90 [PMID:21454438]

492. Ogawa A, Obinata H, Hattori T, Kishi M, Tatei K, Ishikawa O and Izumi T. (2010) Identification and analysis of two splice variants of human G2A generated by alternative splicing. $J$ Pharmacol Exp Ther 332: 469-78 [PMID:19855098]

493. Ohagen A, Devitt A, Kunstman KJ, Gorry PR, Rose PP, Korber B, Taylor J, Levy R, Murphy RL, Wolinsky SM and Gabuzda D. (2003) Genetic and functional analysis of full-length human immunodeficiency virus type 1 env genes derived from brain and blood of patients with AIDS. $J$ Virol 77: 12336-45 [PMID:14581570]

494. Ohki-Hamazaki H, Watase K, Yamamoto K, Ogura H, Yamano M, Yamada K, Maeno H, Imaki J, Kikuyama S and Wada E et al.. (1997) Mice lacking bombesin receptor subtype-3 develop metabolic defects and obesity. Nature 390: 165-9 [PMID:9367152] 
495. Oka S, Ota R, Shima M, Yamashita A and Sugiura T. (2010) GPR35 is a novel lysophosphatidic acid receptor. Biochem Biophys Res Commun 395: 232-7 [PMID:20361937]

496. Okamoto Y, Bernstein JD and Shikano S. (2013) Role of C-terminal membrane-proximal basic residues in cell surface trafficking of HIV coreceptor GPR15 protein. J Biol Chem 288: 9189-99 [PMID:23430259]

497. Okamoto Y and Shikano S. (2011) Phosphorylation-dependent C-terminal binding of 14-3-3 proteins promotes cell surface expression of HIV co-receptor GPR15. J Biol Chem 286: 7171-81 [PMID:21189250]

498. Okubo S, Kurebayashi J, Otsuki T, Yamamoto Y, Tanaka K and Sonoo H. (2004) Additive antitumour effect of the epidermal growth factor receptor tyrosine kinase inhibitor gefitinib (Iressa, ZD1839) and the antioestrogen fulvestrant (Faslodex, ICI 182,780) in breast cancer cells. Br J Cancer 90: 236-44 [PMID:14710235]

499. Onozawa Y, Fujita Y, Kuwabara H, Nagasaki M, Komai T and Oda T. (2012) Activation of T cell death-associated gene 8 regulates the cytokine production of $\mathrm{T}$ cells and macrophages in vitro. Eur J Pharmacol 683: 325-31 [PMID:22445881]

500. Osborn O, Oh da Y, McNelis J, Sanchez-Alavez M, Talukdar S, Lu M, Li P, Thiede L, Morinaga H and Kim JJ et al.. (2012) G protein-coupled receptor 21 deletion improves insulin sensitivity in diet-induced obese mice. J Clin Invest 122: 2444-53 [PMID:22653059]

501. Osmers I, Smith SS, Parks BW, Yu S, Srivastava R, Wohler JE, Barnum SR and Kabarowski JH. (2009) Deletion of the G2A receptor fails to attenuate experimental autoimmune encephalomyelitis. J Neuroimmunol 207: 18-23 [PMID:19135725]

502. Ota T, Suzuki Y, Nishikawa T, Otsuki T, Sugiyama T, Irie R, Wakamatsu A, Hayashi K, Sato H and Nagai K et al.. (2004) Complete sequencing and characterization of 21,243 full-length human cDNAs. Nat Genet 36: 40-5 [PMID:14702039]

503. Owen SM, Masciotra S, Novembre F, Yee J, Switzer WM, Ostyula M and Lal RB. (2000) Simian immunodeficiency viruses of diverse origin can use CXCR4 as a coreceptor for entry into human cells. J Virol 74: 5702-8 [PMID:10823878]

504. Oyama K, Mohri Y, Sone M, Nawa A and Nishimori K. (2011) Conditional knockout of Lgr4 leads to impaired ductal elongation and branching morphogenesis in mouse mammary glands. Sex Dev 5: 205-12 [PMID:21791950]

505. Padmanabhan S, Myers AG and Prasad BM. (2009) Constitutively active GPR6 is located in the intracellular compartments. FEBS Lett 583: 107-12 [PMID:19059244]

506. Pae CU, Drago A, Forlani M, Patkar AA and Serretti A. (2010) Investigation of an epistastic effect between a set of TAAR6 and HSP-70 genes variations and major mood disorders. Am J Med Genet B Neuropsychiatr Genet 153B: 680-3 [PMID:19582769]

507. Pae CU, Drago A, Kim JJ, Patkar AA, Jun TY, De Ronchi D and Serretti A. (2010) TAAR6 variations possibly associated with antidepressant response and suicidal behavior. Psychiatry Res 180: 20-4 [PMID:20493543]

508. Pae CU, Drago A, Mandelli L, De Ronchi D and Serretti A. (2009) TAAR 6 and HSP-70 variations associated with bipolar disorder. Neurosci Lett 465: 257-61 [PMID:19766166]

509. Pae CU, Drago A, Patkar AA, Jun TY and Serretti A. (2009) Epistasis between a set of variations located in the TAAR6 and HSP-70 genes toward schizophrenia and response to antipsychotic treatment. Eur Neuropsychopharmacol 19: 806-11 [PMID:19643584]

510. Pae CU, Yu HS, Amann D, Kim JJ, Lee CU, Lee SJ, Jun TY, Lee C, Paik IH and Patkar AA et al.. (2008) Association of the trace amine associated receptor 6 (TAAR6) gene with schizophrenia and bipolar disorder in a Korean case control sample. J Psychiatr Res 42: 35-40 [PMID:17097106]

511. Pappo AS, Krailo M, Chen Z, Rodriguez-Galindo C and Reaman G. (2010) Infrequent tumor initiative of the Children's Oncology Group: initial lessons learned and their impact on future plans. J Clin Oncol 28: 5011-6 [PMID:20956621]

512. Pariani MJ, Spencer A, Graham JM and Rimoin DL. (2009) A 785kb deletion of 3p14.1p13, including the FOXP1 gene, associated with speech delay, contractures, hypertonia and blepharophimosis. Eur J Med Genet 52: 123-7 [PMID:19332160]

513. Park SJ, Lee SJ, Nam SY and Im DS. (2018) GPR35 mediates lodoxamide-induced migration inhibitory response but not CXCL17-induced migration stimulatory response in THP-1 cells; is GPR35 a receptor for CXCL17? Br J Pharmacol 175: 154-161 [PMID:29068046]

514. Parker R, Liu M, Eyre HJ, Copeland NG, Gilbert DJ, Crawford J, Sutherland GR, Jenkins NA and Herzog H. (2000) Y-receptor-like genes GPR72 and GPR73: molecular cloning, genomic organisation and assignment to human chromosome 11q21.1 and 2p14 and mouse chromosome 9 and 6. Biochim Biophys Acta 1491: 369-75 [PMID:10760605]

515. Parks BW, Gambill GP, Lusis AJ and Kabarowski JH. (2005) Loss of G2A promotes macrophage accumulation in atherosclerotic lesions of low density lipoprotein receptor-deficient mice. J Lipid Res 46: 1405-15 [PMID:15834123]

516. Parks BW, Lusis AJ and Kabarowski JH. (2006) Loss of the lysophosphatidylcholine effector, G2A, ameliorates aortic atherosclerosis in low-density lipoprotein receptor knockout mice. 
Arterioscler Thromb Vasc Biol 26: 2703-9 [PMID:16990555]

517. Parks BW, Srivastava R, Yu S and Kabarowski JH. (2009) ApoE-dependent modulation of HDL and atherosclerosis by G2A in LDL receptor-deficient mice independent of bone marrow-derived cells. Arterioscler Thromb Vasc Biol 29: 539-47 [PMID:19164809]

518. Parravicini C, Ranghino G, Abbracchio MP and Fantucci P. (2008) GPR17: molecular modeling and dynamics studies of the 3-D structure and purinergic ligand binding features in comparison with P2Y receptors. BMC Bioinformatics 9: 263 [PMID:18533035]

519. Pasternack SM, von Kügelgen I, Aboud KA, Lee YA, Rüschendorf F, Voss K, Hillmer AM, Molderings GJ, Franz T, Ramirez A, Nürnberg P, Nöthen MM and Betz RC. (2008) G proteincoupled receptor P2Y5 and its ligand LPA are involved in maintenance of human hair growth. Nat Genet 40: 329-34 [PMID:18297070]

520. Pease JE. (2011) Targeting chemokine receptors in allergic disease. Biochem J 434: 11-24 [PMID:21269275]

521. Pease JE. (2006) Tails of the unexpected - an atypical receptor for the chemokine RANTES/CCL5 expressed in brain. Br J Pharmacol 149: 460-2 [PMID:17001302]

522. Peiró C, Vallejo S, Gembardt F, Azcutia V, Heringer-Walther S, Rodríguez-Mañas L, Schultheiss HP, Sánchez-Ferrer CF and Walther T. (2007) Endothelial dysfunction through genetic deletion or inhibition of the $\mathrm{G}$ protein-coupled receptor Mas: a new target to improve endothelial function. J Hypertens 25: 2421-5 [PMID:17984663]

523. Pereira JP, Kelly LM, Xu Y and Cyster JG. (2009) EBI2 mediates B cell segregation between the outer and centre follicle. Nature 460: 1122-6 [PMID:19597478]

524. Pereverzev A, Komarova SV, Korcok J, Armstrong S, Tremblay GB, Dixon SJ and Sims SM. (2008) Extracellular acidification enhances osteoclast survival through an NFAT-independent, protein kinase C-dependent pathway. Bone 42: 150-61 [PMID:17964236]

525. Perry KJ, Johnson VR, Malloch EL, Fukui L, Wever J, Thomas AG, Hamilton PW and Henry JJ. (2010) The G-protein-coupled receptor, GPR84, is important for eye development in Xenopus laevis. Dev Dyn 239: 3024-37 [PMID:20925114]

526. Pesini P, Detheux M, Parmentier M and Hökfelt T. (1998) Distribution of a glucocorticoidinduced orphan receptor (JP05) mRNA in the central nervous system of the mouse. Brain Res Mol Brain Res 57: 281-300 [PMID:9675427]

527. Petek E, Windpassinger C, Simma B, Mueller T, Wagner K and Kroisel PM. (2003) Molecular characterisation of a $15 \mathrm{Mb}$ constitutional de novo interstitial deletion of chromosome $3 \mathrm{p}$ in a boy with developmental delay and congenital anomalies. J Hum Genet 48: 283-7 [PMID:12836054]

528. Peter C, Waibel M, Radu CG, Yang LV, Witte ON, Schulze-Osthoff K, Wesselborg S and Lauber K. (2008) Migration to apoptotic "find-me" signals is mediated via the phagocyte receptor G2A. $J$ Biol Chem 283: 5296-305 [PMID:18089568]

529. Petersen PS, Jin C, Madsen AN, Rasmussen M, Kuhre R, Egerod KL, Nielsen LB, Schwartz TW and Holst B. (2011) Deficiency of the GPR39 receptor is associated with obesity and altered adipocyte metabolism. FASEB J 25: 3803-14 [PMID:21784784]

530. Peukert S, Hughes R, Nunez J, He G, Yan Z, Jain R, Llamas L, Luchansky S, Carlson A and Liang $\mathrm{G}$ et al.. (2014) Discovery of 2-Pyridylpyrimidines as the First Orally Bioavailable GPR39 Agonists. ACS Med Chem Lett 5: 1114-8 [PMID:25313322]

531. Pillaiyar T, Köse M, Namasivayam V, Sylvester K, Borges G, Thimm D, von Kügelgen I and Müller CE. (2018) 6-(Ar)Alkylamino-Substituted Uracil Derivatives: Lipid Mimetics with Potent Activity at the Orphan G Protein-Coupled Receptor 84 (GPR84). ACS Omega 3: 3365-3383 [PMID:30023867]

532. Pinheiro SV, Ferreira AJ, Kitten GT, da Silveira KD, da Silva DA, Santos SH, Gava E, Castro CH, Magalhães JA and da Mota RK et al.. (2009) Genetic deletion of the angiotensin-(1-7) receptor Mas leads to glomerular hyperfiltration and microalbuminuria. Kidney Int 75: 1184-93 [PMID:19262461]

533. Pinheiro SV, Simões e Silva AC, Sampaio WO, de Paula RD, Mendes EP, Bontempo ED, Pesquero JB, Walther T, Alenina N and Bader M et al.. (2004) Nonpeptide AVE 0991 is an angiotensin-(17) receptor Mas agonist in the mouse kidney. Hypertension 44: 490-6 [PMID:15326087]

534. Pisabarro MT, Leung B, Kwong M, Corpuz R, Frantz GD, Chiang N, Vandlen R, Diehl LJ, Skelton $\mathrm{N}$ and Kim HS et al.. (2006) Cutting edge: novel human dendritic cell- and monocyte-attracting chemokine-like protein identified by fold recognition methods. J Immunol 176: 2069-73 [PMID:16455961]

535. Pitkin SL, Maguire JJ, Bonner TI and Davenport AP. (2010) International Union of Basic and Clinical Pharmacology. LXXIV. Apelin receptor nomenclature, distribution, pharmacology, and function. Pharmacol Rev 62: 331-42 [PMID:20605969]

536. Prchalová E, Hin N, Thomas AG, Veeravalli V, Ng J, Alt J, Rais R, Rojas C, Li Z and Hihara H et al.. (2019) Discovery of Benzamidine- and 1-Aminoisoquinoline-Based Human MAS-Related GProtein-Coupled Receptor X1 (MRGPRX1) Agonists. J Med Chem 62: 8631-8641 [PMID:31498617] 
537. Pringle KG, Tadros MA, Callister RJ and Lumbers ER. (2011) The expression and localization of the human placental prorenin/renin-angiotensin system throughout pregnancy: roles in trophoblast invasion and angiogenesis? Placenta 32: 956-62 [PMID:22018415]

538. Prossnitz ER and Barton M. (2011) The G-protein-coupled estrogen receptor GPER in health and disease. Nat Rev Endocrinol 7: 715-26 [PMID:21844907]

539. Pugliese AM, Trincavelli ML, Lecca D, Coppi E, Fumagalli M, Ferrario S, Failli P, Daniele S, Martini C, Pedata F and Abbracchio MP. (2009) Functional characterization of two isoforms of the P2Y-like receptor GPR17: [35S]GTPgammaS binding and electrophysiological studies in 1321N1 cells. Am J Physiol, Cell Physiol 297: C1028-40 [PMID:19625605]

540. Pukhlik BM, Mzaiĕk V and Zaikov SV. (1991) [Clinico-immunological characteristics of drug allergy in patients with pulmonary tuberculosis]. Probl Tuberk: 46-7 [PMID:1838178]

541. Pöhlmann S, Davis C, Meister S, Leslie GJ, Otto C, Reeves JD, Puffer BA, Papkalla A, Krumbiegel $\mathrm{M}$ and Marzi A et al.. (2004) Amino acid 324 in the simian immunodeficiency virus SIVmac V3 loop can confer CD4 independence and modulate the interaction with CCR5 and alternative coreceptors. J Virol 78: 3223-32 [PMID:15016843]

542. Pöhlmann S, Krumbiegel M and Kirchhoff F. (1999) Coreceptor usage of BOB/GPR15 and Bonzo/STRL33 by primary isolates of human immunodeficiency virus type 1. J Gen Virol 80 ( Pt 5): 1241-51 [PMID:10355771]

543. Pöhlmann S, Lee B, Meister S, Krumbiegel M, Leslie G, Doms RW and Kirchhoff F. (2000) Simian immunodeficiency virus utilizes human and sooty mangabey but not rhesus macaque STRL33 for efficient entry. J Virol 74: 5075-82 [PMID:10799581]

544. Pöhlmann S, Stolte N, Münch J, Ten Haaft P, Heeney JL, Stahl-Hennig C and Kirchhoff F. (1999) Co-receptor usage of BOB/GPR15 in addition to CCR5 has no significant effect on replication of simian immunodeficiency virus in vivo. J Infect Dis 180: 1494-502 [PMID:10515808]

545. Qi AD, Harden TK and Nicholas RA. (2013) Is GPR17 a P2Y/leukotriene receptor? examination of uracil nucleotides, nucleotide sugars, and cysteinyl leukotrienes as agonists of GPR17. J Pharmacol Exp Ther 347: 38-46 [PMID:23908386]

546. QI LL, LU YB, SHI WZ, ZHAO CZ, ZHANG YM, CHEN LP, ZHANG LH, FANG SH, BAO JF, SHEN JG and WEI EQ. (2009) [Preparation and identification of a polyclonal antibody against novel cysteinyl leukotriene receptor GPR17]. Zhejiang Da Xue Xue Bao Yi Xue Ban 38: 357-61 [PMID:19693972]

547. Qi X, Tang J, Pramanik R, Schultz RM, Shirasawa S, Sasazuki T, Han J and Chen G. (2004) p38 MAPK activation selectively induces cell death in K-ras-mutated human colon cancer cells through regulation of vitamin D receptor. J Biol Chem 279: 22138-44 [PMID:15037631]

548. Qiao J, Huang F, Naikawadi RP, Kim KS, Said T and Lum H. (2006) Lysophosphatidylcholine impairs endothelial barrier function through the G protein-coupled receptor GPR4. Am J Physiol Lung Cell Mol Physiol 291: L91-101 [PMID:16461426]

549. Qin Y, Verdegaal EM, Siderius M, Bebelman JP, Smit MJ, Leurs R, Willemze R, Tensen CP and Osanto S. (2011) Quantitative expression profiling of G-protein-coupled receptors (GPCRs) in metastatic melanoma: the constitutively active orphan GPCR GPR18 as novel drug target. Pigment Cell Melanoma Res 24: 207-18 [PMID:20880198]

550. Qu L and Caterina MJ. (2018) Accelerating the reversal of inflammatory pain with NPD1 and its receptor GPR37. J Clin Invest 128: 3246-3249 [PMID:30010628]

551. Rabelo LA, Xu P, Todiras M, Sampaio WO, Buttgereit J, Bader M, Santos RA and Alenina N. (2008) Ablation of angiotensin (1-7) receptor Mas in C57Bl/6 mice causes endothelial dysfunction. J Am Soc Hypertens 2: 418-24 [PMID:20409925]

552. Rabin M, Birnbaum D, Young D, Birchmeier C, Wigler M and Ruddle FH. (1987) Human ros1 and mas1 oncogenes located in regions of chromosome 6 associated with tumor-specific rearrangements. Oncogene Res 1: 169-78 [PMID:3329713]

553. Radu CG, Cheng D, Nijagal A, Riedinger M, McLaughlin J, Yang LV, Johnson J and Witte ON. (2006) Normal immune development and glucocorticoid-induced thymocyte apoptosis in mice deficient for the T-cell death-associated gene 8 receptor. Mol Cell Biol 26: 668-77 [PMID:16382156]

554. Radu CG, Nijagal A, McLaughlin J, Wang L and Witte ON. (2005) Differential proton sensitivity of related G protein-coupled receptors T cell death-associated gene 8 and G2A expressed in immune cells. Proc Natl Acad Sci USA 102: 1632-7 [PMID:15665078]

555. Radu CG, Yang LV, Riedinger M, Au M and Witte ON. (2004) T cell chemotaxis to lysophosphatidylcholine through the G2A receptor. Proc Natl Acad Sci USA 101: 245-50 [PMID:14681556]

556. Rajagopal S, Kim J, Ahn S, Craig S, Lam CM, Gerard NP, Gerard C and Lefkowitz RJ. (2010) Beta-arrestin- but not G protein-mediated signaling by the "decoy" receptor CXCR7. Proc Natl Acad Sci USA 107: 628-32 [PMID:20018651]

557. Rakušan D, Bürgelová M, Vaněčková I, Vaňourková Z, Husková Z, Skaroupková P, Mrázová I, Opočenský M, Kramer HJ and Netuka I et al.. (2010) Knockout of angiotensin 1-7 receptor Mas worsens the course of two-kidney, one-clip Goldblatt hypertension: roles of nitric oxide 
deficiency and enhanced vascular responsiveness to angiotensin II. Kidney Blood Press Res 33: 476-88 [PMID:21071955]

558. Ramachandran V, Arumugam T, Hwang RF, Greenson JK, Simeone DM and Logsdon CD. (2007) Adrenomedullin is expressed in pancreatic cancer and stimulates cell proliferation and invasion in an autocrine manner via the adrenomedullin receptor, ADMR. Cancer Res 67: 2666-75 [PMID:17363587]

559. Ramachandran V, Arumugam T, Langley R, Hwang RF, Vivas-Mejia P, Sood AK, Lopez-Berestein $\mathrm{G}$ and Logsdon CD. (2009) The ADMR receptor mediates the effects of adrenomedullin on pancreatic cancer cells and on cells of the tumor microenvironment. PLoS ONE 4: e7502 [PMID:19847298]

560. Rao A and Herr DR. (2017) G protein-coupled receptor GPR19 regulates E-cadherin expression and invasion of breast cancer cells. Biochim Biophys Acta 1864: 1318-1327 [PMID:28476646]

561. Rao S, Garrett-Sinha LA, Yoon J and Simon MC. (1999) The Ets factors PU.1 and Spi-B regulate the transcription in vivo of P2Y10, a lymphoid restricted heptahelical receptor. J Biol Chem 274: 34245-52 [PMID:10567398]

562. Rau KK, McIlwrath SL, Wang H, Lawson JJ, Jankowski MP, Zylka MJ, Anderson DJ and Koerber HR. (2009) Mrgprd enhances excitability in specific populations of cutaneous murine polymodal nociceptors. J Neurosci 29: 8612-9 [PMID:19571152]

563. Redell MS, Tsimelzon A, Hilsenbeck SG and Tweardy DJ. (2007) Conditional overexpression of Stat3alpha in differentiating myeloid cells results in neutrophil expansion and induces a distinct, antiapoptotic and pro-oncogenic gene expression pattern. J Leukoc Biol 82: 975-85 [PMID:17634277]

564. Reichard HA, Schiffer HH, Monenschein H, Atienza JM, Corbett G, Skaggs AW, Collia DR, Ray WJ, Serrats J and Bliesath J et al.. (2021) Discovery of TAK-041: a Potent and Selective GPR139 Agonist Explored for the Treatment of Negative Symptoms Associated with Schizophrenia. $J$ Med Chem 64: 11527-11542 [PMID:34260228]

565. Ren H, Orozco IJ, Su Y, Suyama S, Gutiérrez-Juárez R, Horvath TL, Wardlaw SL, Plum L, Arancio O and Accili D. (2012) FoxO1 Target Gpr17 Activates AgRP Neurons to Regulate Food Intake. Cell 149: 1314-26 [PMID:22682251]

566. Ren J and Zhang L. (2011) Effects of ovarian cancer G protein coupled receptor 1 on the proliferation, migration, and adhesion of human ovarian cancer cells. Chin Med J 124: 1327-32 [PMID:21740742]

567. Reppert SM, Weaver DR and Godson C. (1996) Melatonin receptors step into the light: cloning and classification of subtypes. Trends Pharmacol Sci 17: 100-2 [PMID:8936344]

568. Revankar CM, Cimino DF, Sklar LA, Arterburn JB and Prossnitz ER. (2005) A transmembrane intracellular estrogen receptor mediates rapid cell signaling. Science 307: 1625-30 [PMID:15705806]

569. Rezgaoui M, Süsens U, Ignatov A, Gelderblom M, Glassmeier G, Franke I, Urny J, Imai Y, Takahashi R and Schaller HC. (2006) The neuropeptide head activator is a high-affinity ligand for the orphan G-protein-coupled receptor GPR37. J Cell Sci 119: 542-9 [PMID:16443751]

570. Riesewijk AM, Schepens MT, Mariman EM, Ropers HH and Kalscheuer VM. (1996) The MAS proto-oncogene is not imprinted in humans. Genomics 35: 380-2 [PMID:8661154]

571. Riker AI, Enkemann SA, Fodstad O, Liu S, Ren S, Morris C, Xi Y, Howell P, Metge B, Samant RS, Shevde LA, Li W, Eschrich S, Daud A, Ju J and Matta J. (2008) The gene expression profiles of primary and metastatic melanoma yields a transition point of tumor progression and metastasis. BMC Med Genomics 1: 13 [PMID:18442402]

572. Rikitake Y, Hirata K, Yamashita T, Iwai K, Kobayashi S, Itoh H, Ozaki M, Ejiri J, Shiomi M and Inoue $\mathrm{N}$ et al.. (2002) Expression of G2A, a receptor for lysophosphatidylcholine, by macrophages in murine, rabbit, and human atherosclerotic plaques. Arterioscler Thromb Vasc Biol 22: 2049-53 [PMID:12482833]

573. Ritscher L, Engemaier E, Stäubert C, Liebscher I, Schmidt P, Hermsdorf T, Römpler H, Schulz A and Schöneberg T. (2012) The ligand specificity of the G-protein-coupled receptor GPR34. Biochem J 443: 841-50 [PMID:22348703]

574. Rivera SP, Saarikoski ST, Sun W and Hankinson O. (2007) Identification of novel dioxinresponsive genes by representational difference analysis. Xenobiotica 37: 271-9 [PMID:17624025]

575. Robas N, Mead E and Fidock M. (2003) MrgX2 is a high potency cortistatin receptor expressed in dorsal root ganglion. J Biol Chem 278: 44400-4 [PMID:12915402]

576. Rosenkilde MM, Benned-Jensen T, Andersen H, Holst PJ, Kledal TN, Lüttichau HR, Larsen JK, Christensen JP and Schwartz TW. (2006) Molecular pharmacological phenotyping of EBI2. An orphan seven-transmembrane receptor with constitutive activity. J Biol Chem 281: 13199-208 [PMID:16540462]

577. Ross PC, Figler RA, Corjay MH, Barber CM, Adam N, Harcus DR and Lynch KR. (1990) RTA, a candidate $\mathrm{G}$ protein-coupled receptor: cloning, sequencing, and tissue distribution. Proc Natl Acad Sci USA 87: 3052-6 [PMID:2109324] 
578. Rossi P, Dolci S, Sette C, Capolunghi F, Pellegrini M, Loiarro M, Di Agostino S, Paronetto MP, Grimaldi P, Merico D, Martegani E and Geremia R. (2004) Analysis of the gene expression profile of mouse male meiotic germ cells. Gene Expr Patterns 4: 267-81 [PMID:15053975]

579. Rosu-Myles M, Khandaker M, Wu DM, Keeney M, Foley SR, Howson-Jan K, Yee IC, Fellows F, Kelvin D and Bhatia M. (2000) Characterization of chemokine receptors expressed in primitive blood cells during human hematopoietic ontogeny. Stem Cells 18: 374-81 [PMID:11007922]

580. Roth RB, Hevezi P, Lee J, Willhite D, Lechner SM, Foster AC and Zlotnik A. (2006) Gene expression analyses reveal molecular relationships among 20 regions of the human CNS. Neurogenetics 7: 67-80 [PMID:16572319]

581. Rubic T, Lametschwandtner G, Jost S, Hinteregger S, Kund J, Carballido-Perrig N, Schwärzler C, Junt T, Voshol H and Meingassner JG et al.. (2008) Triggering the succinate receptor GPR91 on dendritic cells enhances immunity. Nat Immunol 9: 1261-9 [PMID:18820681]

582. Ruffner H, Sprunger J, Charlat O, Leighton-Davies J, Grosshans B, Salathe A, Zietzling S, Beck $\mathrm{V}$, Therier M and Isken A et al.. (2012) R-Spondin potentiates Wnt/B-catenin signaling through orphan receptors LGR4 and LGR5. PLoS ONE 7: e40976 [PMID:22815884]

583. Ruiz-Medina J, Ledent C and Valverde O. (2011) GPR3 orphan receptor is involved in neuropathic pain after peripheral nerve injury and regulates morphine-induced antinociception. Neuropharmacology 61: 43-50 [PMID:21352831]

584. Russell JL, Goetsch SC, Aguilar HR, Coe H, Luo X, Liu N, van Rooij E, Frantz DE and Schneider JW. (2012) Regulated expression of pH sensing G Protein-coupled receptor-68 identified through chemical biology defines a new drug target for ischemic heart disease. ACS Chem Biol 7: 107783 [PMID:22462679]

585. Ryder C, McColl K, Zhong F and Distelhorst CW. (2012) Acidosis Promotes Bcl-2 Familymediated Evasion of Apoptosis: INVOLVEMENT OF ACID-SENSING G PROTEIN-COUPLED RECEPTOR GPR65 SIGNALING TO MEK/ERK. J Biol Chem 287: 27863-75 [PMID:22685289]

586. Römpler H, Schulz A, Pitra C, Coop G, Przeworski M, Pääbo S and Schöneberg T. (2005) The rise and fall of the chemoattractant receptor GPR33. J Biol Chem 280: 31068-75 [PMID:15987686]

587. Römpler H, Yu HT, Arnold A, Orth A and Schöneberg T. (2006) Functional consequences of naturally occurring DRY motif variants in the mammalian chemoattractant receptor GPR33. Genomics 87: 724-32 [PMID:16595170]

588. Saeki Y, Ueno S, Mizuno R, Nishimura T, Fujimura H, Nagai Y and Yanagihara T. (1993) Molecular cloning of a novel putative G protein-coupled receptor (GPCR21) which is expressed predominantly in mouse central nervous system. FEBS Lett 336: 317-22 [PMID:8262253]

589. Sah R, Parker SL, Sheriff S, Eaton K, Balasubramaniam A and Sallee FR. (2007) Interaction of NPY compounds with the rat glucocorticoid-induced receptor (GIR) reveals similarity to the NPY-Y2 receptor. Peptides 28: 302-9 [PMID:17240481]

590. Sah R, Pritchard LM, Richtand NM, Ahlbrand R, Eaton K, Sallee FR and Herman JP. (2005) Expression of the glucocorticoid-induced receptor mRNA in rat brain. Neuroscience 133: 281-92 [PMID:15893650]

591. Sampaio WO, Souza dos Santos RA, Faria-Silva R, da Mata Machado LT, Schiffrin EL and Touyz RM. (2007) Angiotensin-(1-7) through receptor Mas mediates endothelial nitric oxide synthase activation via Akt-dependent pathways. Hypertension 49: 185-92 [PMID:17116756]

592. Sanderlin EJ, Leffler NR, Lertpiriyapong K, Cai Q, Hong H, Bakthavatchalu V, Fox JG, Oswald JZ, Justus CR and Krewson EA et al.. (2017) GPR4 deficiency alleviates intestinal inflammation in a mouse model of acute experimental colitis. Biochim Biophys Acta Mol Basis Dis 1863: 569584 [PMID:27940273]

593. Sanders AR, Duan J, Levinson DF, Shi J, He D, Hou C, Burrell GJ, Rice JP, Nertney DA, Olincy A, Rozic P, Vinogradov S, Buccola NG, Mowry BJ, Freedman R, Amin F, Black DW, Silverman JM, Byerley WF, Crowe RR, Cloninger CR, Martinez M and Gejman PV. (2008) No significant association of 14 candidate genes with schizophrenia in a large European ancestry sample: implications for psychiatric genetics. Am J Psychiatry 165: 497-506 [PMID:18198266]

594. Santos EL, Reis RI, Silva RG, Shimuta SI, Pecher C, Bascands JL, Schanstra JP, Oliveira L, Bader $\mathrm{M}$ and Paiva AC et al.. (2007) Functional rescue of a defective angiotensin II AT1 receptor mutant by the Mas protooncogene. Regul Pept 141: 159-67 [PMID:17320985]

595. Santos RA, Castro CH, Gava E, Pinheiro SV, Almeida AP, Paula RD, Cruz JS, Ramos AS, Rosa KT and Irigoyen MC et al.. (2006) Impairment of in vitro and in vivo heart function in angiotensin(1-7) receptor MAS knockout mice. Hypertension 47: 996-1002 [PMID:16567589]

596. Santos RA, Haibara AS, Campagnole-Santos MJ, Simões e Silva AC, Paula RD, Pinheiro SV, Leite MF, Lemos VS, Silva DM and Guerra MT et al.. (2003) Characterization of a new selective antagonist for angiotensin-(1-7), D-pro7-angiotensin-(1-7). Hypertension 41: 737-43 [PMID:12623989]

597. Santos RA, Simoes e Silva AC, Maric C, Silva DM, Machado RP, de Buhr I, Heringer-Walther S, Pinheiro SV, Lopes MT and Bader M et al.. (2003) Angiotensin-(1-7) is an endogenous ligand for the G protein-coupled receptor Mas. Proc Natl Acad Sci USA 100: 8258-63 [PMID:12829792] 
598. Santos SH, Fernandes LR, Mario EG, Ferreira AV, Pôrto LC, Alvarez-Leite JI, Botion LM, Bader $\mathrm{M}$, Alenina N and Santos RA. (2008) Mas deficiency in FVB/N mice produces marked changes in lipid and glycemic metabolism. Diabetes 57: 340-7 [PMID:18025412]

599. Sauer CG, White K, Stöhr H, Grimm T, Hutchinson A, Bernstein PS, Lewis RA, Simonelli F, Pauleikhoff D, Allikmets R and Weber BH. (2001) Evaluation of the G protein coupled receptor75 (GPR75) in age related macular degeneration. Br J Ophthalmol 85: 969-75 [PMID:11466257]

600. Savergnini SQ, Beiman M, Lautner RQ, de Paula-Carvalho V, Allahdadi K, Pessoa DC, CostaFraga FP, Fraga-Silva RA, Cojocaru G and Cohen Y et al.. (2010) Vascular relaxation, antihypertensive effect, and cardioprotection of a novel peptide agonist of the MAS receptor. Hypertension 56: 112-20 [PMID:20479330]

601. Sawzdargo M, George SR, Nguyen T, Xu S, Kolakowski LF and O'Dowd BF. (1997) A cluster of four novel human $\mathrm{G}$ protein-coupled receptor genes occurring in close proximity to CD22 gene on chromosome 19q13.1. Biochem Biophys Res Commun 239: 543-7 [PMID:9344866]

602. Sawzdargo M, Nguyen T, Lee DK, Lynch KR, Cheng R, Heng HH, George SR and O'Dowd BF. (1999) Identification and cloning of three novel human $\mathrm{G}$ protein-coupled receptor genes GPR52, PsiGPR53 and GPR55: GPR55 is extensively expressed in human brain. Brain Res Mol Brain Res 64: 193-8 [PMID:9931487]

603. Saxena H, Deshpande DA, Tiegs BC, Yan H, Battafarano RJ, Burrows WM, Damera G, Panettieri RA, Dubose TD and An SS et al.. (2012) The GPCR OGR1 (GPR68) mediates diverse signalling and contraction of airway smooth muscle in response to small reductions in extracellular $\mathrm{pH}$. $\mathrm{Br}$ J Pharmacol 166: 981-90 [PMID:22145625]

604. Schaub A, Fütterer A and Pfeffer K. (2001) PUMA-G, an IFN-gamma-inducible gene in macrophages is a novel member of the seven transmembrane spanning receptor superfamily. Eur J Immunol 31: 3714-25 [PMID:11745392]

605. Schenten D, Marcon L, Karlsson GB, Parolin C, Kodama T, Gerard N and Sodroski J. (1999) Effects of soluble CD4 on simian immunodeficiency virus infection of CD4-positive and CD4negative cells. J Virol 73: 5373-80 [PMID:10364284]

606. Schimenti JC. (1999) ORFless, intronless, and mutant transcription units in the mouse t complex responder (Tcr) locus. Mamm Genome 10: 969-76 [PMID:10501965]

607. Schweifer N, Valk PJ, Delwel R, Cox R, Francis F, Meier-Ewert S, Lehrach H and Barlow DP. (1997) Characterization of the C3 YAC contig from proximal mouse chromosome 17 and analysis of allelic expression of genes flanking the imprinted Igf2r gene. Genomics 43: 285-97 [PMID:9268631]

608. Schöneberg T, Schulz A, Grosse R, Schade R, Henklein P, Schultz G and Gudermann T. (1999) A novel subgroup of class I G-protein-coupled receptors. Biochim Biophys Acta 1446: 57-70 [PMID:10395919]

609. Sellick GS, Coleman RJ, Webb EL, Chow J, Bevan S, Rosbotham JL and Houlston RS. (2005) Dominantly inherited cutaneous small-vessel lymphocytic vasculitis maps to chromosome 6q26q27. Hum Genet 118: 82-6 [PMID:16133183]

610. Serretti A, Pae CU, Chiesa A, Mandelli L and De Ronchi D. (2009) Influence of TAAR6 polymorphisms on response to aripiprazole. Prog Neuropsychopharmacol Biol Psychiatry 33: 822-6 [PMID:19345712]

611. Setoh M, Ishii N, Kono M, Miyanohana Y, Shiraishi E, Harasawa T, Ota H, Odani T, Kanzaki N and Aoyama K et al.. (2014) Discovery of the first potent and orally available agonist of the orphan G-protein-coupled receptor 52. J Med Chem 57: 5226-37 [PMID:24884590]

612. Setty MK, Devadas K, Ragupathy V, Ravichandran V, Tang S, Wood O, Gaddam DS, Lee S and Hewlett IK. (2011) XMRV: usage of receptors and potential co-receptors. Virol J 8: 423 [PMID:21896167]

613. Seuwen K, Ludwig MG and Wolf RM. (2006) Receptors for protons or lipid messengers or both? J Recept Signal Transduct Res 26: 599-610 [PMID:17118800]

614. Shaffer AL, Yu X, He Y, Boldrick J, Chan EP and Staudt LM. (2000) BCL-6 represses genes that function in lymphocyte differentiation, inflammation, and cell cycle control. Immunity 13: 199212 [PMID:10981963]

615. Shemesh R, Toporik A, Levine Z, Hecht I, Rotman G, Wool A, Dahary D, Gofer E, Kliger Y and Soffer MA et al.. (2008) Discovery and validation of novel peptide agonists for G-protein-coupled receptors. J Biol Chem 283: 34643-9 [PMID:18854305]

616. Shi F, Shen JK, Chen D, Fog K, Thirstrup K, Hentzer M, Karlsson JJ, Menon V, Jones KA and Smith KE et al.. (2011) Discovery and SAR of a Series of Agonists at Orphan G Protein-Coupled Receptor 139. ACS Med Chem Lett 2: 303-6 [PMID:24900311]

617. Shields SD, Cavanaugh DJ, Lee H, Anderson DJ and Basbaum AI. (2010) Pain behavior in the formalin test persists after ablation of the great majority of C-fiber nociceptors. Pain 151: 422-9 [PMID:20832171]

618. Shinohara T, Harada M, Ogi K, Maruyama M, Fujii R, Tanaka H, Fukusumi S, Komatsu H, Hosoya M and Noguchi Y et al.. (2004) Identification of a G protein-coupled receptor specifically responsive to beta-alanine. J Biol Chem 279: 23559-64 [PMID:15037633] 
619. Shyy W, Wang K, Gurnett CA, Dobbs MB, Miller NH, Wise C, Sheffield VC and Morcuende JA. (2010) Evaluation of GPR50, hMel-1B, and ROR-alpha melatonin-related receptors and the etiology of adolescent idiopathic scoliosis. J Pediatr Orthop 30: 539-43 [PMID:20733416]

620. Sidibe A, Mullier A, Chen P, Baroncini M, Boutin JA, Delagrange P, Prevot V and Jockers R. (2010) Expression of the orphan GPR50 protein in rodent and human dorsomedial hypothalamus, tanycytes and median eminence. J Pineal Res 48: 263-9 [PMID:20210849]

621. Sikand P, Dong X and LaMotte RH. (2011) BAM8-22 peptide produces itch and nociceptive sensations in humans independent of histamine release. J Neurosci 31: 7563-7 [PMID:21593341]

622. Sin WC, Zhang Y, Zhong W, Adhikarakunnathu S, Powers S, Hoey T, An S and Yang J. (2004) G protein-coupled receptors GPR4 and TDAG8 are oncogenic and overexpressed in human cancers. Oncogene 23: 6299-303 [PMID:15221007]

623. Singh A, Besson G, Mobasher A and Collman RG. (1999) Patterns of chemokine receptor fusion cofactor utilization by human immunodeficiency virus type 1 variants from the lungs and blood. $J$ Virol 73: 6680-90 [PMID:10400765]

624. Singh G and Davenport AP. (2006) Neuropeptide B and W: neurotransmitters in an emerging Gprotein-coupled receptor system. Br J Pharmacol 148: 1033-41 [PMID:16847439]

625. Slominski A, Pisarchik A, Zbytek B, Tobin DJ, Kauser S and Wortsman J. (2003) Functional activity of serotoninergic and melatoninergic systems expressed in the skin. J Cell Physiol 196: 144-53 [PMID:12767050]

626. Snippert HJ, Haegebarth A, Kasper M, Jaks V, van Es JH, Barker N, van de Wetering M, van den Born M, Begthel H, Vries RG, Stange DE, Toftgård R and Clevers H. (2010) Lgr6 marks stem cells in the hair follicle that generate all cell lineages of the skin. Science 327: 1385-9 [PMID:20223988]

627. Solinski HJ, Gudermann T and Breit A. (2014) Pharmacology and signaling of MAS-related G protein-coupled receptors. Pharmacol Rev 66: 570-97 [PMID:24867890]

628. Song H, Luo J, Luo W, Weng J, Wang Z, Li B, Li D and Liu M. (2008) Inactivation of G-proteincoupled receptor 48 (Gpr48/Lgr4) impairs definitive erythropoiesis at midgestation through down-regulation of the ATF4 signaling pathway. J Biol Chem 283: 36687-97 [PMID:18955481]

629. Song ZH, Modi W and Bonner TI. (1995) Molecular cloning and chromosomal localization of human genes encoding three closely related G protein-coupled receptors. Genomics 28: 347-9 [PMID:8530049]

630. Southern C, Cook JM, Neetoo-Isseljee Z, Taylor DL, Kettleborough CA, Merritt A, Bassoni DL, Raab WJ, Quinn E and Wehrman TS et al.. (2013) Screening B-Arrestin Recruitment for the Identification of Natural Ligands for Orphan G-Protein-Coupled Receptors. J Biomol Screen 18: 599-609 [PMID:23396314]

631. Sreedharan S, Almén MS, Carlini VP, Haitina T, Stephansson O, Sommer WH, Heilig M, de Barioglio SR, Fredriksson R and Schiöth HB. (2011) The G protein coupled receptor Gpr153 shares common evolutionary origin with Gpr162 and is highly expressed in central regions including the thalamus, cerebellum and the arcuate nucleus. FEBS J 278: 4881-94 [PMID:21981325]

632. Stein LM, Yosten GL and Samson WK. (2016) Adropin acts in brain to inhibit water drinking: potential interaction with the orphan G protein-coupled receptor, GPR19. Am J Physiol Regul Integr Comp Physiol 310: R476-80 [PMID:26739651]

633. Stoddart LA, Smith NJ and Milligan G. (2008) International Union of Pharmacology. LXXI. Free fatty acid receptors FFA1, -2, and -3: pharmacology and pathophysiological functions.

Pharmacol Rev 60: 405-17 [PMID:19047536]

634. Storjohann L, Holst B and Schwartz TW. (2008) Molecular mechanism of Zn2+ agonism in the extracellular domain of GPR39. FEBS Lett 582: 2583-8 [PMID:18588883]

635. Storlazzi CT, Albano F, Lo Cunsolo C, Doglioni C, Guastadisegni MC, Impera L, Lonoce A, Funes S, Macrì E, Iuzzolino P, Panagopoulos I, Specchia G and Rocchi M. (2007) Upregulation of the SOX5 by promoter swapping with the P2RY8 gene in primary splenic follicular lymphoma. Leukemia 21: 2221-5 [PMID:17554380]

636. Stäubert C, Böselt I, Bohnekamp J, Römpler H, Enard W and Schöneberg T. (2010) Structural and functional evolution of the trace amine-associated receptors TAAR3, TAAR4 and TAAR5 in primates. PLoS ONE 5: e11133 [PMID:20559446]

637. Subramanian H, Gupta K and Ali H. (2016) Roles of Mas-related G protein-coupled receptor X2 on mast cell-mediated host defense, pseudoallergic drug reactions, and chronic inflammatory diseases. J Allergy Clin Immunol 138: 700-10 [PMID:27448446]

638. Subramanian H, Gupta K, Guo Q, Price R and Ali H. (2011) Mas-related gene X2 (MrgX2) is a novel G protein-coupled receptor for the antimicrobial peptide LL-37 in human mast cells: resistance to receptor phosphorylation, desensitization, and internalization. J Biol Chem 286: 44739-49 [PMID:22069323]

639. Subramanian H, Kashem SW, Collington SJ, Qu H, Lambris JD and Ali H. (2011) PMX-53 as a dual CD88 antagonist and an agonist for Mas-related gene 2 (MrgX2) in human mast cells. Mol 
Pharmacol 79: 1005-13 [PMID:21441599]

640. Sugimoto N, Oida T, Hirota K, Nakamura K, Nomura T, Uchiyama T and Sakaguchi S. (2006) Foxp3-dependent and -independent molecules specific for CD25+CD4+ natural regulatory T cells revealed by DNA microarray analysis. Int Immunol 18: 1197-209 [PMID:16772372]

641. Sugita K, Yamamura C, Tabata K and Fujita N. (2013) Expression of orphan G-protein coupled receptor GPR174 in CHO cells induced morphological changes and proliferation delay via increasing intracellular cAMP. Biochem Biophys Res Commun 430: 190-5 [PMID:23178570]

642. Sugo T and Mori M. (2008) Another ligand fishing for G protein-coupled receptor 14. Discovery of urotensin II-related peptide in the rat brain. Peptides 29: 809-12 [PMID:17628210]

643. Sugo T, Tachimoto H, Chikatsu T, Murakami Y, Kikukawa Y, Sato S, Kikuchi K, Nagi T, Harada M, Ogi K, Ebisawa M and Mori M. (2006) Identification of a lysophosphatidylserine receptor on mast cells. Biochem Biophys Res Commun 341: 1078-87 [PMID:16460680]

644. Sumida H, Noguchi K, Kihara Y, Abe M, Yanagida K, Hamano F, Sato S, Tamaki K, Morishita Y and Kano MR et al.. (2010) LPA4 regulates blood and lymphatic vessel formation during mouse embryogenesis. Blood 116: 5060-70 [PMID:20713964]

645. Sun H, Monenschein H, Schiffer HH, Reichard HA, Kikuchi S, Hopkins M, Macklin TK, Hitchcock S, Adams M and Green J et al.. (2021) First-Time Disclosure of CVN424, a Potent and Selective GPR6 Inverse Agonist for the Treatment of Parkinson's Disease: Discovery, Pharmacological Validation, and Identification of a Clinical Candidate. J Med Chem [PMID:33861086]

646. Sun X, Yang LV, Tiegs BC, Arend LJ, McGraw DW, Penn RB and Petrovic S. (2010) Deletion of the $\mathrm{pH}$ sensor GPR4 decreases renal acid excretion. J Am Soc Nephrol 21: 1745-55 [PMID:20798260]

647. Suply T, Hannedouche S, Carte N, Li J, Grosshans B, Schaefer M, Raad L, Beck V, Vidal S and Hiou-Feige A et al.. (2017) A natural ligand for the orphan receptor GPR15 modulates lymphocyte recruitment to epithelia. Sci Signal 10 [PMID:28900043]

648. Suzuki M, Takaishi S, Nagasaki M, Onozawa Y, Iino I, Maeda H, Komai T and Oda T. (2013) Medium-chain Fatty Acid-sensing Receptor, GPR84, Is a Proinflammatory Receptor. J Biol Chem 288: 10684-91 [PMID:23449982]

649. Swan C, Duroudier NP, Campbell E, Zaitoun A, Hastings M, Dukes GE, Cox J, Kelly FM, Wilde J and Lennon MG et al.. (2013) Identifying and testing candidate genetic polymorphisms in the irritable bowel syndrome (IBS): association with TNFSF15 and TNF $\alpha$. Gut 62: 985-94 [PMID:22684480]

650. Süsens U, Hermans-Borgmeyer I, Urny J and Schaller HC. (2006) Characterisation and differential expression of two very closely related G-protein-coupled receptors, GPR139 and GPR142, in mouse tissue and during mouse development. Neuropharmacology 50: 512-20 [PMID:16378626]

651. Tabata K, Baba K, Shiraishi A, Ito M and Fujita N. (2007) The orphan GPCR GPR87 was deorphanized and shown to be a lysophosphatidic acid receptor. Biochem Biophys Res Commun 363: 861-6 [PMID:17905198]

652. Takeda S, Okada T, Okamura M, Haga T, Isoyama-Tanaka J, Kuwahara H and Minamino N. (2004) The receptor-Galpha fusion protein as a tool for ligand screening: a model study using a nociceptin receptor-Galphai2 fusion protein. J Biochem 135: 597-604 [PMID:15173198]

653. Tallant EA, Ferrario CM and Gallagher PE. (2005) Angiotensin-(1-7) inhibits growth of cardiac myocytes through activation of the mas receptor. Am J Physiol Heart Circ Physiol 289: H1560-6 [PMID:15951342]

654. Tanaka S, Ishii K, Kasai K, Yoon SO and Saeki Y. (2007) Neural expression of G protein-coupled receptors GPR3, GPR6, and GPR12 up-regulates cyclic AMP levels and promotes neurite outgrowth. J Biol Chem 282: 10506-15 [PMID:17284443]

655. Tanaka S, Shaikh IM, Chiocca EA and Saeki Y. (2009) The Gs-linked receptor GPR3 inhibits the proliferation of cerebellar granule cells during postnatal development. PLoS ONE 4: e5922 [PMID:19526062]

656. Taniguchi Y, Tonai-Kachi H and Shinjo K. (2006) Zaprinast, a well-known cyclic guanosine monophosphate-specific phosphodiesterase inhibitor, is an agonist for GPR35. FEBS Lett 580: 5003-8 [PMID:16934253]

657. Tarttelin EE, Kirschner LS, Bellingham J, Baffi J, Taymans SE, Gregory-Evans K, Csaky K, Stratakis CA and Gregory-Evans CY. (1999) Cloning and characterization of a novel orphan Gprotein-coupled receptor localized to human chromosome 2p16. Biochem Biophys Res Commun 260: 174-80 [PMID:10381362]

658. Tatemoto K, Nozaki Y, Tsuda R, Konno S, Tomura K, Furuno M, Ogasawara H, Edamura K, Takagi $\mathrm{H}$ and Iwamura $\mathrm{H}$ et al.. (2006) Immunoglobulin E-independent activation of mast cell is mediated by Mrg receptors. Biochem Biophys Res Commun 349: 1322-8 [PMID:16979137]

659. Thathiah A, Spittaels K, Hoffmann M, Staes M, Cohen A, Horré K, Vanbrabant M, Coun F, Baekelandt V, Delacourte A, Fischer DF, Pollet D, De Strooper B and Merchiers P. (2009) The orphan G protein-coupled receptor 3 modulates amyloid-beta peptide generation in neurons. 
Science 323: 946-951 [PMID:19213921]

660. Thimm D, Funke M, Meyer A and Müller CE. (2013) 6-Bromo-8-(4-[(3)H]methoxybenzamido)-4oxo-4H-chromene-2-carboxylic Acid: a powerful tool for studying orphan G protein-coupled receptor GPR35. J Med Chem 56: 7084-99 [PMID:23888932]

661. Thomas P, Pang Y, Filardo EJ and Dong J. (2005) Identity of an estrogen membrane receptor coupled to a G protein in human breast cancer cells. Endocrinology 146: 624-32 [PMID:15539556]

662. Thomson PA, Wray NR, Thomson AM, Dunbar DR, Grassie MA, Condie A, Walker MT, Smith DJ, Pulford DJ, Muir W, Blackwood DH and Porteous DJ. (2005) Sex-specific association between bipolar affective disorder in women and GPR50, an X-linked orphan G protein-coupled receptor. Mol Psychiatry 10: 470-8 [PMID:15452587]

663. Tobo A, Tobo M, Nakakura T, Ebara M, Tomura H, Mogi C, Im DS, Murata N, Kuwabara A and Ito S et al.. (2015) Characterization of Imidazopyridine Compounds as Negative Allosteric Modulators of Proton-Sensing GPR4 in Extracellular Acidification-Induced Responses. PLoS ONE 10: e0129334 [PMID:26070068]

664. Tobo M, Tomura H, Mogi C, Wang JQ, Liu JP, Komachi M, Damirin A, Kimura T, Murata N, Kurose H, Sato K and Okajima F. (2007) Previously postulated "ligand-independent" signaling of GPR4 is mediated through proton-sensing mechanisms. Cell Signal 19: 1745-53 [PMID:17462861]

665. Toda N, Hao X, Ogawa Y, Oda K, Yu M, Fu Z, Chen Y, Kim Y, Lizarzaburu M and Lively S et al.. (2013) Potent and Orally Bioavailable GPR142 Agonists as Novel Insulin Secretagogues for the Treatment of Type 2 Diabetes. ACS Med Chem Lett 4: 790-4 [PMID:24900747]

666. Toma I, Kang JJ, Sipos A, Vargas S, Bansal E, Hanner F, Meer E and Peti-Peterdi J. (2008) Succinate receptor GPR91 provides a direct link between high glucose levels and renin release in murine and rabbit kidney. J Clin Invest 118: 2526-34 [PMID:18535668]

667. Toms C, Jessup H, Thompson C, Baban D, Davies K and Powrie F. (2008) Gpr83 expression is not required for the maintenance of intestinal immune homeostasis and regulation of T-celldependent colitis. Immunology 125: 302-12 [PMID:18479351]

668. Tomura H, Mogi C, Sato K and Okajima F. (2005) Proton-sensing and lysolipid-sensitive Gprotein-coupled receptors: a novel type of multi-functional receptors. Cell Signal 17: 1466-76 [PMID:16014326]

669. Tomura H, Wang JQ, Komachi M, Damirin A, Mogi C, Tobo M, Kon J, Misawa N, Sato K and Okajima F. (2005) Prostaglandin I(2) production and cAMP accumulation in response to acidic extracellular pH through OGR1 in human aortic smooth muscle cells. J Biol Chem 280: $34458-64$ [PMID:16087674]

670. Tomura H, Wang JQ, Liu JP, Komachi M, Damirin A, Mogi C, Tobo M, Nochi H, Tamoto K, Im DS, Sato K and Okajima F. (2008) Cyclooxygenase-2 expression and prostaglandin E2 production in response to acidic pH through OGR1 in a human osteoblastic cell line. J Bone Miner Res 23: 1129-39 [PMID:18302504]

671. Toyooka M, Tujii T and Takeda S. (2009) The N-terminal domain of GPR61, an orphan G-proteincoupled receptor, is essential for its constitutive activity. J Neurosci Res 87: 1329-33 [PMID:19025769]

672. Toyota M, Kopecky KJ, Toyota MO, Jair KW, Willman CL and Issa JP. (2001) Methylation profiling in acute myeloid leukemia. Blood 97: 2823-9 [PMID:11313277]

673. Tremblay F, Perreault M, Klaman LD, Tobin JF, Smith E and Gimeno RE. (2007) Normal food intake and body weight in mice lacking the G protein-coupled receptor GPR39. Endocrinology 148: 501-6 [PMID:17095592]

674. Trent JM, Thompson FH and Meyskens FL. (1989) Identification of a recurring translocation site involving chromosome 6 in human malignant melanoma. Cancer Res 49: 420-3 [PMID:2642739]

675. Trivellin G, Daly AF, Faucz FR, Yuan B, Rostomyan L, Larco DO, Schernthaner-Reiter MH, Szarek E, Leal LF and Caberg JH et al.. (2014) Gigantism and acromegaly due to Xq26 microduplications and GPR101 mutation. $N$ Engl J Med 371: 2363-74 [PMID:25470569]

676. Tyler WA, Jain MR, Cifelli SE, Li Q, Ku L, Feng Y, Li H and Wood TL. (2011) Proteomic identification of novel targets regulated by the mammalian target of rapamycin pathway during oligodendrocyte differentiation. Glia 59: 1754-69 [PMID:21858874]

677. Uhlenbrock K, Gassenhuber H and Kostenis E. (2002) Sphingosine 1-phosphate is a ligand of the human gpr3, gpr6 and gpr12 family of constitutively active $\mathrm{G}$ protein-coupled receptors. Cell Signal 14: 941-953 [PMID:12220620]

678. Uhlenbrock K, Huber J, Ardati A, Busch AE and Kostenis E. (2003) Fluid shear stress differentially regulates gpr3, gpr6, and gpr12 expression in human umbilical vein endothelial cells. Cell Physiol Biochem 13: 75-84 [PMID:12649592]

679. Underwood SL, Christoforou A, Thomson PA, Wray NR, Tenesa A, Whittaker J, Adams RA, Le Hellard S, Morris SW, Blackwood DH, Muir WJ, Porteous DJ and Evans KL. (2006) Association analysis of the chromosome 4p-located G protein-coupled receptor 78 (GPR78) gene in bipolar affective disorder and schizophrenia. Mol Psychiatry 11: 384-94 [PMID:16389273] 
680. Unutmaz D, KewalRamani VN and Littman DR. (1998) G protein-coupled receptors in HIV and SIV entry: new perspectives on lentivirus-host interactions and on the utility of animal models. Semin Immunol 10: 225-36 [PMID:9653049]

681. Valdenaire O, Giller T, Breu V, Ardati A, Schweizer A and Richards JG. (1998) A new family of orphan G protein-coupled receptors predominantly expressed in the brain. FEBS Lett 424: 1936 [PMID:9539149]

682. Valdes AM and Spector TD. (2010) The genetic epidemiology of osteoarthritis. Curr Opin Rheumatol 22: 139-43 [PMID:20090528]

683. Valverde O, Célérier E, Baranyi M, Vanderhaeghen P, Maldonado R, Sperlagh B, Vassart G and Ledent C. (2009) GPR3 receptor, a novel actor in the emotional-like responses. PLOS ONE 4: e4704 [PMID:19259266]

684. van Hagen PM, Dalm VA, Staal F and Hofland LJ. (2008) The role of cortistatin in the human immune system. Mol Cell Endocrinol 286: 141-7 [PMID:18450367]

685. Van Schoore G, Mendive F, Pochet R and Vassart G. (2005) Expression pattern of the orphan receptor LGR4/GPR48 gene in the mouse. Histochem Cell Biol 124: 35-50 [PMID:16028069]

686. Vanti WB, Muglia P, Nguyen T, Cheng R, Kennedy JL, George SR and O'Dowd BF. (2003) Discovery of a null mutation in a human trace amine receptor gene. Genomics 82: 531-536 [PMID:14559210]

687. Vanti WB, Nguyen T, Cheng R, Lynch KR, George SR and O'Dowd BF. (2003) Novel human Gprotein-coupled receptors. Biochem Biophys Res Commun 305: 67-71 [PMID:12732197]

688. Velcicky J, Miltz W, Oberhauser B, Orain D, Vaupel A, Weigand K, Dawson King J, LittlewoodEvans A, Nash M and Feifel R et al.. (2017) Development of Selective, Orally Active GPR4 Antagonists with Modulatory Effects on Nociception, Inflammation, and Angiogenesis. J Med Chem 60: 3672-3683 [PMID:28445047]

689. Venkataraman C and Kuo F. (2005) The G-protein coupled receptor, GPR84 regulates IL-4 production by $\mathrm{T}$ lymphocytes in response to CD3 crosslinking. Immunol Lett 101: 144-53 [PMID:15993493]

690. Villar AJ and Pedersen RA. (1994) Parental imprinting of the Mas protooncogene in mouse. Nat Genet 8: 373-9 [PMID:7894489]

691. Vladimirov VI, Maher BS, Wormley B, O'Neill FA, Walsh D, Kendler KS and Riley BP. (2009) The trace amine associated receptor (TAAR6) gene is not associated with schizophrenia in the Irish Case-Control Study of Schizophrenia (ICCSS) sample. Schizophr Res 107: 249-54 [PMID:18973992]

692. Von Bohlen und Halbach O, Walther T, Bader M and Albrecht D. (2000) Interaction between Mas and the angiotensin AT1 receptor in the amygdala. J Neurophysiol 83: 2012-21 [PMID:10758111]

693. Vödrös D and Fenyö EM. (2005) Quantitative evaluation of HIV and SIV co-receptor use with GHOST(3) cell assay. Methods Mol Biol 304: 333-42 [PMID:16061987]

694. Vödrös D, Thorstensson R, Biberfeld G, Schols D, De Clercq E and Fenyö EM. (2001) Coreceptor usage of sequential isolates from cynomolgus monkeys experimentally Infected with simian immunodeficiency virus (SIVsm). Virology 291: 12-21 [PMID:11878872]

695. Vödrös D, Thorstensson R, Doms RW, Fenyö EM and Reeves JD. (2003) Evolution of coreceptor use and CD4-independence in envelope clones derived from SIVsm-infected macaques. Virology 316: 17-28 [PMID:14599787]

696. Wallrabenstein I, Kuklan J, Weber L, Zborala S, Werner M, Altmüller J, Becker C, Schmidt A, Hatt $\mathrm{H}$ and Hummel $\mathrm{T}$ et al.. (2013) Human trace amine-associated receptor TAAR5 can be activated by trimethylamine. PLOS ONE 8: e54950 [PMID:23393561]

697. Walther T, Balschun D, Voigt JP, Fink H, Zuschratter W, Birchmeier C, Ganten D and Bader M. (1998) Sustained long term potentiation and anxiety in mice lacking the Mas protooncogene. $J$ Biol Chem 273: 11867-73 [PMID:9565612]

698. Walther T, Wessel N, Kang N, Sander A, Tschöpe C, Malberg H, Bader M and Voss A. (2000) Altered heart rate and blood pressure variability in mice lacking the Mas protooncogene. Braz J Med Biol Res 33: 1-9 [PMID:10625868]

699. Wan ES, Qiu W, Baccarelli A, Carey VJ, Bacherman H, Rennard SI, Agusti A, Anderson W, Lomas DA and Demeo DL. (2012) Cigarette smoking behaviors and time since quitting are associated with differential DNA methylation across the human genome. Hum Mol Genet 21: 3073-82 [PMID:22492999]

700. Wang C, Dehghani B, Magrisso IJ, Rick EA, Bonhomme E, Cody DB, Elenich LA, Subramanian S, Murphy SJ and Kelly MJ et al.. (2008) GPR30 contributes to estrogen-induced thymic atrophy. Mol Endocrinol 22: 636-48 [PMID:18063692]

701. Wang D, Herman JP, Pritchard LM, Spitzer RH, Ahlbrand RL, Kramer GL, Petty F, Sallee FR and Richtand NM. (2001) Cloning, expression, and regulation of a glucocorticoid-induced receptor in rat brain: effect of repetitive amphetamine. J Neurosci 21: 9027-35 [PMID:11698613]

702. Wang D, Huang B, Zhang S, Yu X, Wu W and Wang X. (2013) Structural basis for R-spondin recognition by LGR4/5/6 receptors. Genes Dev 27: 1339-44 [PMID:23756652] 
703. Wang D, Stoveken HM, Zucca S, Dao M, Orlandi C, Song C, Masuho I, Johnston C, Opperman KJ and Giles AC et al.. (2019) Genetic behavioral screen identifies an orphan anti-opioid system. Science 365: 1267-1273 [PMID:31416932]

704. Wang H and Zylka MJ. (2009) Mrgprd-expressing polymodal nociceptive neurons innervate most known classes of substantia gelatinosa neurons. J Neurosci 29: 13202-9 [PMID:19846708]

705. Wang HQ, Imai Y, Inoue H, Kataoka A, Iita S, Nukina N and Takahashi R. (2008) Pael-R transgenic mice crossed with parkin deficient mice displayed progressive and selective catecholaminergic neuronal loss. J Neurochem 107: 171-85 [PMID:18691389]

706. Wang J, Duhart HM, Xu Z, Patterson TA, Newport GD and Ali SF. (2008) Comparison of the time courses of selective gene expression and dopaminergic depletion induced by MPP+ in MN9D cells. Neurochem Int 52: 1037-43 [PMID:18069091]

707. Wang J, Li X, Ke Y, Lu Y, Wang F, Fan N, Sun H, Zhang H, Liu R and Yang J et al.. (2012) GPR48 increases mineralocorticoid receptor gene expression. J Am Soc Nephrol 23: 281-93 [PMID:22135314]

708. Wang J, Simonavicius N, Wu X, Swaminath G, Reagan J, Tian H and Ling L. (2006) Kynurenic acid as a ligand for orphan G protein-coupled receptor GPR35. J Biol Chem 281: 22021-8 [PMID:16754668]

709. Wang J, Wu X, Simonavicius N, Tian H and Ling L. (2006) Medium-chain fatty acids as ligands for orphan G protein-coupled receptor GPR84. J Biol Chem 281: 34457-64 [PMID:16966319]

710. Wang J, Zhu LY, Liu Q, Hentzer M, Smith GP and Wang MW. (2015) High-throughput screening of antagonists for the orphan G-protein coupled receptor GPR139. Acta Pharmacol Sin 36: 874-8 [PMID:26027661]

711. Wang JQ, Kon J, Mogi C, Tobo M, Damirin A, Sato K, Komachi M, Malchinkhuu E, Murata N, Kimura T, Kuwabara A, Wakamatsu K, Koizumi H, Uede T, Tsujimoto G, Kurose H, Sato T, Harada A, Misawa N, Tomura H and Okajima F. (2004) TDAG8 is a proton-sensing and psychosine-sensitive G-protein-coupled receptor. J Biol Chem 279: 45626-33 [PMID:15326175]

712. Wang Y, de Vallière C, Imenez Silva PH, Leonardi I, Gruber S, Gerstgrasser A, Melhem H, Weber A, Leucht K and Wolfram L et al.. (2018) The Proton-activated Receptor GPR4 Modulates Intestinal Inflammation. J Crohns Colitis 12: 355-368 [PMID:29136128]

713. Wang Y, Pringle KG, Sykes SD, Marques FZ, Morris BJ, Zakar T and Lumbers ER. (2012) Fetal sex affects expression of renin-angiotensin system components in term human decidua. Endocrinology 153: 462-8 [PMID:22045662]

714. Wang Z, Jin C, Li H, Li C, Hou Q, Liu M, Dong Xda E and Tu L. (2010) GPR48-Induced keratinocyte proliferation occurs through HB-EGF mediated EGFR transactivation. FEBS Lett 584: 4057-62 [PMID:20732323]

715. Wei X, Walia V, Lin JC, Teer JK, Prickett TD, Gartner J, Davis S, NISC Comparative Sequencing Program, Stemke-Hale K and Davies MA et al.. (2011) Exome sequencing identifies GRIN2A as frequently mutated in melanoma. Nat Genet 43: 442-6 [PMID:21499247]

716. Weiler A, May GE, Qi Y, Wilson N and Watkins DI. (2006) Polymorphisms in eight host genes associated with control of HIV replication do not mediate elite control of viral replication in SIVinfected Indian rhesus macaques. Immunogenetics 58: 1003-9 [PMID:17106666]

717. Weng J, Luo J, Cheng X, Jin C, Zhou X, Qu J, Tu L, Ai D, Li D, Wang J, Martin JF, Amendt BA and Liu M. (2008) Deletion of G protein-coupled receptor 48 leads to ocular anterior segment dysgenesis (ASD) through down-regulation of Pitx2. Proc Natl Acad Sci USA 105: 6081-6 [PMID:18424556]

718. Weng Z, Fluckiger AC, Nisitani S, Wahl MI, Le LQ, Hunter CA, Fernal AA, Le Beau MM and Witte ON. (1998) A DNA damage and stress inducible G protein-coupled receptor blocks cells in G2/M. Proc Natl Acad Sci USA 95: 12334-9 [PMID:9770487]

719. Whyte LS, Ryberg E, Sims NA, Ridge SA, Mackie K, Greasley PJ, Ross RA and Rogers MJ. (2009) The putative cannabinoid receptor GPR55 affects osteoclast function in vitro and bone mass in vivo. Proc Natl Acad Sci USA 106: 16511-6 [PMID:19805329]

720. Wiemer G, Dobrucki LW, Louka FR, Malinski T and Heitsch H. (2002) AVE 0991, a nonpeptide mimic of the effects of angiotensin-(1-7) on the endothelium. Hypertension 40: 847-52 [PMID:12468568]

721. Williams JR, Khandoga AL, Goyal P, Fells JI, Perygin DH, Siess W, Parrill AL, Tigyi G and Fujiwara Y. (2009) Unique ligand selectivity of the GPR92/LPA5 lysophosphatidate receptor indicates role in human platelet activation. J Biol Chem 284: 17304-19 [PMID:19366702]

722. Wilson SR, Gerhold KA, Bifolck-Fisher A, Liu Q, Patel KN, Dong X and Bautista DM. (2011) TRPA1 is required for histamine-independent, Mas-related G protein-coupled receptor-mediated itch. Nat Neurosci 14: 595-602 [PMID:21460831]

723. Witte ON, Kabarowski JH, Xu Y, Le LQ and Zhu K. (2005) Retraction. Science 307: 206 [PMID:15653487]

724. Wittenberger T, Schaller HC and Hellebrand S. (2001) An expressed sequence tag (EST) data mining strategy succeeding in the discovery of new G-protein coupled receptors. J Mol Biol 307: 799-813 [PMID:11273702] 
725. Wunder F, Tinel H, Kast R, Geerts A, Becker EM, Kolkhof P, Hütter J, Ergüden J and Härter M. (2010) Pharmacological characterization of the first potent and selective antagonist at the cysteinyl leukotriene 2 (CysLT(2)) receptor. Br J Pharmacol 160: 399-409 [PMID:20423349]

726. Wyder L, Suply T, Ricoux B, Billy E, Schnell C, Baumgarten BU, Maira SM, Koelbing C, Ferretti $\mathrm{M}$ and Kinzel B et al.. (2011) Reduced pathological angiogenesis and tumor growth in mice lacking GPR4, a proton sensing receptor. Angiogenesis 14: 533-44 [PMID:22045552]

727. Xi L, Junjian Z, Yumin L, Yunwen L and Hongbin W. (2009) Serum biomarkers of vascular cognitive impairment evaluated by bead-based proteomic technology. Neurosci Lett 463: 6-11 [PMID:19631719]

728. Xiao L, Rudolph DL, Owen SM, Spira TJ and Lal RB. (1998) Adaptation to promiscuous usage of CC and CXC-chemokine coreceptors in vivo correlates with HIV-1 disease progression. AIDS 12: F137-43 [PMID:9764773]

729. Xiao XQ, Grove KL, Lau SY, McWeeney S and Smith MS. (2005) Deoxyribonucleic acid microarray analysis of gene expression pattern in the arcuate nucleus/ventromedial nucleus of hypothalamus during lactation. Endocrinology 146: 4391-8 [PMID:16002521]

730. Xu P, Costa-Goncalves AC, Todiras M, Rabelo LA, Sampaio WO, Moura MM, Santos SS, Luft FC, Bader M and Gross V et al.. (2008) Endothelial dysfunction and elevated blood pressure in MAS gene-deleted mice. Hypertension 51: 574-80 [PMID:18180400]

731. Xu P, Santos RA, Bader M and Alenina N. (2007) Alterations in gene expression in the testis of angiotensin-(1-7)-receptor Mas-deficient mice. Regul Pept 138: 51-5 [PMID:17196677]

732. Xu X, Quiambao AB, Roveri L, Pardue MT, Marx JL, Röhlich P, Peachey NS and Al-Ubaidi MR. (2000) Degeneration of cone photoreceptors induced by expression of the Mas1 protooncogene. Exp Neurol 163: 207-19 [PMID:10785460]

733. Xu Y. (2002) Sphingosylphosphorylcholine and lysophosphatidylcholine: G protein-coupled receptors and receptor-mediated signal transduction. Biochim Biophys Acta 1582: 81-8 [PMID:12069813]

734. Xu Y and Casey G. (1996) Identification of human OGR1, a novel G protein-coupled receptor that maps to chromosome 14. Genomics 35: 397-402 [PMID:8661159]

735. Xu Y, Zhu K, Hong G, Wu W, Baudhuin LM, Xiao Y and Damron DS. (2000) Sphingosylphosphorylcholine is a ligand for ovarian cancer G-protein-coupled receptor 1. Nat Cell Biol 2: 261-7 [PMID:10806476]

736. Yamashita R, Takegawa Y, Sakumoto M, Nakahara M, Kawazu H, Hoshii T, Araki K, Yokouchi Y and Yamamura K. (2009) Defective development of the gall bladder and cystic duct in Lgr4hypomorphic mice. Dev Dyn 238: 993-1000 [PMID:19301403]

737. Yanagida K, Masago K, Nakanishi H, Kihara Y, Hamano F, Tajima Y, Taguchi R, Shimizu T and Ishii S. (2009) Identification and characterization of a novel lysophosphatidic acid receptor, p2y5/LPA6. J Biol Chem 284: 17731-41 [PMID:19386608]

738. Yang C, Yang Q and Compans RW. (2000) Coreceptor-dependent inhibition of the cell fusion activity of simian immunodeficiency virus Env proteins. J Virol 74: 6217-22 [PMID:10846110]

739. Yang LV, Radu CG, Roy M, Lee S, McLaughlin J, Teitell MA, Iruela-Arispe ML and Witte ON. (2007) Vascular abnormalities in mice deficient for the G protein-coupled receptor GPR4 that functions as a pH sensor. Mol Cell Biol 27: 1334-47 [PMID:17145776]

740. Yang LV, Radu CG, Wang L, Riedinger M and Witte ON. (2005) Gi-independent macrophage chemotaxis to lysophosphatidylcholine via the immunoregulatory GPCR G2A. Blood 105: 112734 [PMID:15383458]

741. Yang M, Mailhot G, Birnbaum MJ, MacKay CA, Mason-Savas A and Odgren PR. (2006) Expression of and role for ovarian cancer G-protein-coupled receptor 1 (OGR1) during osteoclastogenesis. J Biol Chem 281: 23598-605 [PMID:16787916]

742. Yang Y, Fu A, Wu X and Reagan JD. (2012) GPR35 is a target of the loop diuretic drugs bumetanide and furosemide. Pharmacology 89: 13-7 [PMID:22236570]

743. Yasuda H, Hirata S, Inoue K, Mashima H, Ohnishi H and Yoshiba M. (2007) Involvement of membrane-type bile acid receptor M-BAR/TGR5 in bile acid-induced activation of epidermal growth factor receptor and mitogen-activated protein kinases in gastric carcinoma cells. Biochem Biophys Res Commun 354: 154-9 [PMID:17214962]

744. Yasuda S, Miyazaki T, Munechika K, Yamashita M, Ikeda Y and Kamizono A. (2007) Isolation of $\mathrm{Zn} 2+$ as an endogenous agonist of GPR39 from fetal bovine serum. J Recept Signal Transduct Res 27: 235-46 [PMID:17885920]

745. Ye C, Zhang Z, Wang Z, Hua Q, Zhang R and Xie X. (2014) Identification of a novel smallmolecule agonist for human G protein-coupled receptor 3. J Pharmacol Exp Ther 349: 437-43 [PMID:24633425]

746. Yee KK, Li Y, Redding KM, Iwatsuki K, Margolskee RF and Jiang P. (2013) Lgr5-EGFP marks taste bud stem/progenitor cells in posterior tongue. Stem Cells 31: 992-1000 [PMID:23377989]

747. Yin H, Chu A, Li W, Wang B, Shelton F, Otero F, Nguyen DG, Caldwell JS and Chen YA. (2009) Lipid G protein-coupled receptor ligand identification using beta-arrestin PathHunter assay. $J$ Biol Chem 284: 12328-12338 [PMID:19286662] 
748. Yosten GL, Kolar GR, Redlinger LJ and Samson WK. (2013) Evidence for an interaction between proinsulin C-peptide and GPR146. J Endocrinol 218: B1-8 [PMID:23759446]

749. Yotsumoto S, Shimada T, Cui CY, Nakashima H, Fujiwara H and Ko MS. (1998) Expression of adrenomedullin, a hypotensive peptide, in the trophoblast giant cells at the embryo implantation site in mouse. Dev Biol 203: 264-75 [PMID:9808778]

750. Young D, O'Neill K, Jessell T and Wigler M. (1988) Characterization of the rat mas oncogene and its high-level expression in the hippocampus and cerebral cortex of rat brain. Proc Natl Acad Sci USA 85: 5339-42 [PMID:2455902]

751. Young D, Waitches G, Birchmeier C, Fasano O and Wigler M. (1986) Isolation and characterization of a new cellular oncogene encoding a protein with multiple potential transmembrane domains. Cell 45: 711-9 [PMID:3708691]

752. Yousefi S, Cooper PR, Potter SL, Mueck B and Jarai G. (2001) Cloning and expression analysis of a novel G-protein-coupled receptor selectively expressed on granulocytes. J Leukoc Biol 69: 1045-52 [PMID:11404393]

753. Yu M, Lizarzaburu M, Motani A, Fu Z, Du X, Liu JJ, Jiao X, Lai S, Fan P and Fu A et al.. (2013) Aminopyrazole-Phenylalanine Based GPR142 Agonists: Discovery of Tool Compound and in Vivo Efficacy Studies. ACS Med Chem Lett 4: 829-34 [PMID:24900757]

754. Yu X, Huang XP, Kenakin TP, Slocum ST, Chen X, Martini ML, Liu J and Jin J. (2019) Design, Synthesis, and Characterization of Ogerin-Based Positive Allosteric Modulators for G ProteinCoupled Receptor 68 (GPR68). J Med Chem 62: 7557-7574 [PMID:31298539]

755. Zabel BA, Silverio AM and Butcher EC. (2005) Chemokine-like receptor 1 expression and chemerin-directed chemotaxis distinguish plasmacytoid from myeloid dendritic cells in human blood. J Immunol 174: 244-51 [PMID:15611246]

756. Zaslavsky A, Singh LS, Tan H, Ding H, Liang Z and Xu Y. (2006) Homo- and hetero-dimerization of LPA/S1P receptors, OGR1 and GPR4. Biochim Biophys Acta 1761: 1200-12 [PMID:17023202]

757. Zeng Z, Fan P, Rand E, Kyaw H, Su K, Madike V, Carter KC and Li Y. (1998) Cloning of a putative human neurotransmitter receptor expressed in skeletal muscle and brain. Biochem Biophys Res Commun 242: 575-8 [PMID:9464258]

758. Zeng Z, Su K, Kyaw H and Li Y. (1997) A novel endothelin receptor type-B-like gene enriched in the brain. Biochem Biophys Res Commun 233: 559-67 [PMID:9144577]

759. Zhang JC, Xie YF, Liu SJ, Dai LB and Li JP. (2010) [The expression of melatonin receptor in human hypertrophic scar]. Zhonghua Zheng Xing Wai Ke Za Zhi 26: 203-7 [PMID:20737950]

760. Zhang JV, Klein C, Ren P, Kass S, Ver Donck L, Moechars D and Hsueh AJW. (2007) Response to Comment on "Obestatin, a Peptide Encoded by the Ghrelin Gene, Opposes Ghrelin's Effects on Food Intake". Science 315: 766d

761. Zhang JV, Ren PG, Avsian-Kretchmer O, Luo CW, Rauch R, Klein C and Hsueh AJ. (2005) Obestatin, a peptide encoded by the ghrelin gene, opposes ghrelin's effects on food intake. Science 310: 996-9 [PMID:16284174]

762. Zhang L, He T, Huang Y, Chen Z, Guo Y, Wu S, Kunstman KJ, Brown RC, Phair JP and Neumann AU et al.. (1998) Chemokine coreceptor usage by diverse primary isolates of human immunodeficiency virus type 1.J Virol 72: 9307-12 [PMID:9765480]

763. Zhang L, Taylor N, Xie Y, Ford R, Johnson J, Paulsen JE and Bates B. (2005) Cloning and expression of MRG receptors in macaque, mouse, and human. Brain Res Mol Brain Res 133: 187-97 [PMID:15710235]

764. Zhang LL, Wang JJ, Liu Y, Lu XB, Kuang Y, Wan YH, Chen Y, Yan HM, Fei J and Wang ZG. (2011) GPR26-deficient mice display increased anxiety- and depression-like behaviors accompanied by reduced phosphorylated cyclic AMP responsive element-binding protein level in central amygdala. Neuroscience 196: 203-14 [PMID:21924326]

765. Zhang LY, Jia MR and Sun T. (2018) The roles of special proresolving mediators in pain relief. Rev Neurosci 29: 645-660 [PMID:29420307]

766. Zhang M and Xia G. (2012) Hormonal control of mammalian oocyte meiosis at diplotene stage. Cell Mol Life Sci 69: 1279-88 [PMID:22045555]

767. Zhang T, Li Z, Dang H, Chen R, Liaw C, Tran TA, Boatman PD, Connolly DT and Adams JW. (2012) Inhibition of Mas G-protein signaling improves coronary blood flow, reduces myocardial infarct size, and provides long-term cardioprotection. Am J Physiol Heart Circ Physiol 302: H299-311 [PMID:22003054]

768. Zhao B, Zhao CZ, Zhang XY, Huang XQ, Shi WZ, Fang SH, Lu YB, Zhang WP, Xia Q and Wei EQ. (2012) The new P2Y-like receptor G protein-coupled receptor 17 mediates acute neuronal injury and late microgliosis after focal cerebral ischemia in rats. Neuroscience 202: 42-57 [PMID:22155652]

769. Zhao P, Sharir H, Kapur A, Cowan A, Geller EB, Adler MW, Seltzman HH, Reggio PH, HeynenGenel S, Sauer M, Chung TD, Bai Y, Chen W, Caron MG, Barak LS and Abood ME. (2010) Targeting of the orphan receptor GPR35 by pamoic acid: a potent activator of extracellular signal-regulated kinase and $\beta$-arrestin2 with antinociceptive activity. Mol Pharmacol 78: 560-8 [PMID:20826425] 
770. Zhao SX, Xue LQ, Liu W, Gu ZH, Pan CM, Yang SY, Zhan M, Wang HN, Liang J and Gao GQ et al.. (2013) Robust evidence for five new Graves' disease risk loci from a staged genome-wide association analysis. Hum Mol Genet 22: 3347-62 [PMID:23612905]

771. Zhu K, Baudhuin LM, Hong G, Williams FS, Cristina KL, Kabarowski JH, Witte ON and Xu Y. (2001) Sphingosylphosphorylcholine and lysophosphatidylcholine are ligands for the G proteincoupled receptor GPR4. J Biol Chem 276: 41325-35 [PMID:11535583]

772. Zingoni A, Rocchi M, Storlazzi CT, Bernardini G, Santoni A and Napolitano M. (1997) Isolation and chromosomal localization of GPR31, a human gene encoding a putative G protein-coupled receptor. Genomics 42: 519-23 [PMID:9205127]

773. Zohn IE, Klinger M, Karp X, Kirk H, Symons M, Chrzanowska-Wodnicka M, Der CJ and Kay RJ. (2000) G2A is an oncogenic G protein-coupled receptor. Oncogene 19: 3866-77 [PMID:10951580]

774. Zohn IE, Symons M, Chrzanowska-Wodnicka M, Westwick JK and Der CJ. (1998) Mas oncogene signaling and transformation require the small GTP-binding protein Rac. Mol Cell Biol 18: 122535 [PMID:9488437]

775. Zucchi R, Chiellini G, Scanlan TS and Grandy DK. (2006) Trace amine-associated receptors and their ligands. Br J Pharmacol 149: 967-78 [PMID:17088868]

776. Zylka MJ, Dong X, Southwell AL and Anderson DJ. (2003) Atypical expansion in mice of the sensory neuron-specific Mrg G protein-coupled receptor family. Proc Natl Acad Sci USA 100: 10043-8 [PMID:12909716]

777. Zylka MJ, Rice FL and Anderson DJ. (2005) Topographically distinct epidermal nociceptive circuits revealed by axonal tracers targeted to Mrgprd. Neuron 45: 17-25 [PMID:15629699] 